\title{
Un año en la corte de Enrique III de Castilla (1397-1398)*
}

\section{A Year at the Court of Enrique III of Castile (1397-1398)}

\section{RESUMEN}

\author{
David Nogales Rincón \\ Universidad Complutense. Madrid \\ dnogales@ucm.es
}

\begin{abstract}
En la sección Patronato Real del Archivo General de Simancas (Valladolid, España), bajo la signatura legajo $\mathrm{n}^{\circ} 29$, documento $\mathrm{n}^{\mathrm{0}} 28$ se conserva el documento que, con el título atribuido de Relación de efectos que Pedro Fernández recibía y entregaba de orden del rey, en la actualidad inédito, alude a la realidad de la cámara regia del rey Enrique III de Castilla (1390-1406), entre los días 27 de agosto de 1397 y 18 de agosto de 1398. El presente trabajo buscará estudiar algunos aspectos institucionales, culturales, materiales e históricos de la corte castellana a fines del siglo XIV.
\end{abstract}

Palabras clave: Castilla, Trastámaras, Enrique III, Realeza, Cámara, Corte.

\begin{abstract}
The Archivo General de Simancas (Valladolid, Spain) contains in the Patronato Real section (legajo ${ }^{\circ}$ 29, document $\mathrm{n}^{\mathrm{O}} 28$ ) a document entitled Relación de efectos que Pedro Fernández recibía y entregaba de orden del rey (List of Items Received and Delivered by Pedro Fernández on the King's Orders). This unpublished record contains information regarding the household of King Enrique III of Castile (13901406) between 27 August, 1397 and 18 August, 1398. This study aims at examining some of the institutional, cultural, material and historical aspects of the Court of Castile at the end of the fourteenth century.
\end{abstract}

Key words: Castile, Trastamaras, Enrique III of Castile, Kingship, Chamber, Court.

Sumario: 1. Introducción. 2. La corte de Enrique III de Castilla. 3. La itinerancia cortesana: desde Bonilla de la Sierra hasta Tordesillas. 4. La cultura material en la corte de Enrique III: el patrimonio de la cámara regia. 4.1. Introducción. 4.2. La indumentaria cortesana. 4.3. Los ornamentos litúrgicos y el oratorio de la capilla real. 4.4. La orfebrería cortesana. 4.5. Otros objetos de uso cotidiano. 5. Cinco notas en torno a la Relación de efectos sobre la vida cotidiana y cultural en la corte de Enrique III. 5.1. Navidad y Semana Santa en la corte del rey. 5.2. La práctica de la medicina: una receta médica para el rey. 5.3. El libro del Regimiento de los príncipes y algunas notas sobre la educación cortesana a fines del trescientos. 5.4. Un anillo sigilar de Enrique III: sobre una práctica en la cancillería y la cimera del grifo de los reyes de Castilla. 5.5. Dos juglares del rey de Aragón en Castilla: el cambio poético y musical en la corte de Enrique III. 6. El reflejo de los acontecimientos de la política internacional entre los años 1397-1398: el fecho de la guerra de Portugal. 7. Conclusiones.

* Este trabajo ha sido posible gracias a una ayuda del Plan Nacional de Investigación Científica, Desarrollo e Innovación Tecnológica (subprograma Juan de la Cierva) de la Secretaría de Estado de Investigación, Desarrollo e Innovación del Ministerio de Economía y Competitividad del Gobierno de España. Dicho trabajo forma parte igualmente del Proyecto de la Secretaría de Estado de Investigación, Desarrollo e Innovación ${ }^{\circ}$ HAR2010-16762 titulado Prácticas de consenso y de pacto e instrumentos de representación en la cultura política castellana (siglos XIII al XV), dirigido por José Manuel Nieto Soria. Querría expresar mi deuda con la Dra. Covadonga Valdaliso Casanova (Centro de História da Sociedade e da Cultura, Universidade de Coimbra), con quien realicé de forma conjunta una transcripción preliminar del documento que sirve de base a este trabajo. Este trabajo fue presentado parcialmente, en una ponencia conjunta con la referida investigadora, bajo el título de The Material Environment of Castilian King Henry III (1390-1406), en el congreso 9th European Social Science History Conference Glasgow, celebrado en Glasgow (Reino Unido) entre los días 11-14 de abril de 2012. 


\section{INTRODUCCIÓN}

En la sección Patronato Real del Archivo General de Simancas, bajo la signatura legajo 29, documento 28 se conserva el documento que, con el título atribuido de Relación de efectos que Pedro Fernández recibía y entregaba de orden del rey', en la actualidad inédito, alude a la realidad de la cámara del rey Enrique III de Castilla (1390-1406). La Relación de efectos constituye un registro de las distintas operaciones de recepción y entrega de los bienes y patrimonio de la cámara regia bajo control directo del camarero real Pedro Fernández durante el período comprendido entre los días 27 de agosto de 1397 y 18 de agosto de 1398.

La Relación de efectos constituye un documento de relevancia para el conocimiento de la realidad cortesana castellana de fines del siglo XIV, debido, fundamentalmente, a la ausencia para el período de registros conservados de la cancillería real ${ }^{2}$ y al hecho de que la crónica oficial del reinado, la Crónica de Enrique III, escrita por Pero López de Ayala, no atienda a este período específico, al finalizar en el año quinto del reinado, o sea, $1395^{3}$. Adicionalmente, dicho documento se incorpora a un limitado número de fragmentos de libros de registro vinculados a la cámara del rey de Castilla, susceptibles de convertirse en fuente privilegiada para el estudio del contexto material, burocrático, hacendístico e institucional de la casa y corte regias durante el período trastámara previo al reinado de Isabel I de Castilla ${ }^{4}$.

\section{LA CORTE DE ENRIQUE III DE CASTILLA}

La Relación de efectos ofrece diversas informaciones sobre los miembros adscritos a la corte regia, entendida esta en la acepción clásica ofrecida por las Partidas como "el lugar do es el rey, et sus vasallos et sus oficiales con él (...) et los otros del regno que se llegan hí o por honra dél, o por alcanzar derecho, o por facer recabdar las otras

${ }^{1}$ Se trata este del título atribuido en la descripción del Portal de Archivos Españoles (PARES), incluyéndose una variante del mismo en el catálogo correspondiente a la sección Patronato Real del Archivo General de Simancas, como Relación de las ropas, paños, hilo de oro, alhajas y otros efectos que Pedro Fernández recibía y entregaba de orden del Rey, en Prieto Cantero, A.: Catálogo V. Patronato Real (834-1851), Valladolid, 1946, t. I, p. 410.

${ }^{2}$ Véase al respecto: López Gutiérrez, A. J.: "Los registros de la Cancillería castellana", en La escritura de la memoria: los registros, Barcelona, 2011, pp. 39-72; Arribas Arranz, F.: "Los registros de cancillería de Castilla", Boletín de la Real Academia de la Historia, 162:2 (1968), pp. 171-200; ArRIBAS Arranz, F.: "Los registros de cancillería de Castilla (continuación)", Boletín de la Real Academia de la Historia, 163:1 (1968), pp. 143-162.

3 Orduna, G.: "Pero López de Ayala", en C. Alvar; J.M. Lucía Megías, J. M. (eds.): Diccionario Filológico de Literatura Medieval Española, Madrid, 2002, pp. 875-912, pp. 892-895; WILKINGS, C.L.; WiLKINGS, H.M.: "Introduction", en Coronica de Enrique III, Madison, 1993, pp. V-XXVI, p. VII; Gómez Redondo, F.: Historia de la prosa medieval castellana. III. Los orígenes del humanismo. El marco cultural de Enrique III y Juan II, Madrid, 2002, pp. 2099-2100.

${ }^{4}$ Sobre estas, véanse las referencias recopiladas en CAÑAS GÁlvez, F. de P.: "La cámara de Juan II: vida privada, ceremonia y lujo en la corte de Castilla a mediados del siglo XV", en Evolución y estructura de la Casa Real de Castilla, Madrid, 2010, vol. I, pp. 81-195, p. 84. 
cosas que han de veer con él"', dibujando así un organigrama parcial y fragmentario de la misma, a partir del núcleo constituido por la cámara regia ${ }^{6}$.

Entre los principales personajes citados en la Relación de efectos, generalmente como beneficiarios de donaciones, mercedes o salarios, podemos citar, junto al omnipresente Enrique III, a Ruy López Dávalos, camarero de Enrique III; al conde de Trastámara, Pedro Enríquez; a Alfonso, futuro Alfonso V de Aragón; a Pedro Carrillo de Huete; a Pero López de Ayala y su hijo, criado de Enrique III, del mismo nombre, referidos respectivamente como el Mayor y el Mozo; al adelantado Pedro Suárez de León; a Gonzalo Núñez de Guzmán, maestre de Calatrava; al infante Fernando de Antequera, hermano del rey; a Pero Niño, por entonces un simple doncel del rey; a Juan Hurtado de Mendoza; a Diego López de Estúñiga, justicia mayor en la casa real; a Enrique de Castilla, duque de Medina Sidonia; a la reina, Catalina de Lancaster; a Martín Vázquez de Acuña; o al infante Dinis de Portugal (Dionís II de Portugal).

En estas líneas se dan cita algunos de los más estrechos colaboradores del monarca, integradores de una nueva oligarquía cortesana, llamados a ser, en palabras de Juan Torres Fontes, "los más eficaces ejecutores del programa político de restablecimiento del poder real" ", cuya plantilla, encabezada por los referidos Juan Hurtado de Mendoza, Ruy López Dávalos y Diego López de Estúñiga ${ }^{8}$, hubo de quedar completada, según Luis Suárez Fernández, en torno a 1393-1394․ Esta nueva oligarquía ha sido caracterizada como una nobleza engrandecida, socialmente vinculada a los ricos hombres o a la pequeña nobleza y definida políticamente como un grupo con vocación de ejercer el control político en la corte regia y aspiraciones de constituirse en clase política ${ }^{10}$. El ascenso de esta oligarquía se produciría en el marco de un proceso fundamentado, en palabras de Fernando Suárez Bilbao, en el intento de "eliminar a los grandes -es decir, el duque de Benavente, el marqués de Villena, y los condes de Noreña, de Trastámara y de Niebla- de los oficios reales y, por este medio, de acuerdo con la experiencia recogida durante la minoridad, también del gobierno" En este sentido, el ascenso de dicha oligarquía completaría el proceso de renovación

${ }^{5}$ Alfonso X, Las Siete Partidas del Rey Don Alfonso El Sabio, cotejadas con varios códices antiguos por la Real Academia de la Historia, Madrid, 1807, t. II, Partida II, Título IX, Ley XXVII, p. 82.

${ }^{6}$ Sobre la cámara de Enrique III se encuentra en preparación un trabajo complementario a este que aquí presentamos, cuyo título provisional es: "La cámara de Enrique III de Castilla, conforme a la Relación de efectos que Pedro Fernández recibía y entregaba por orden del rey (Archivo General de Simancas, Patronato Real, legajo 29, documento 28)".

7 Torres Fontes, J.: "Los condestables de Castilla en la Edad Media", Anuario de Historia del Derecho Español, 41 (1971), pp. 57-112, p. 68.

${ }^{8}$ Guerrero Navarrete, Y.: Proceso y sentencia contra Ruy López Dávalos, Condestable de Castilla, Jaén, 1982, p. 45.

9 Suárez Fernández, L.: "Nobleza y monarquía en la política de Enrique III", Hispania: Revista Española de Historia, 48 (1952), pp. 323-400, p. 333.

${ }^{10}$ SuÁrez Fernández, L.: "Nobleza y monarquía...", p. 333; Mitre Fernández, E.: Evolución de la nobleza en Castilla bajo Enrique III (1396-1406), Valladolid, 1968, pp. 24, 130-131; SuÁrez Bilbao, F.: "La transformación de la institución nobiliaria en tiempos de Enrique III", en Medievo hispano. Estudios in memoriam del Prof. Derek W. Lomax, Madrid, 1995, pp. 345-360, pp. 358-359; SúARez Bilbao, F.: "Enrique III, rey de León y Castilla: el cambio institucional (1391-1396)", Archivos Leoneses, 93-94 (1993), pp. 77-232, pp. 195-196.

${ }^{11}$ SuÁrez Bilbao, F.: "La transformación...”, p. 345; Súarez Bilbao, F.: “Enrique III...”, p. 182. 
nobiliaria'2 ${ }^{2}$ que, como apunta Luis Suárez Fernández, “extraía de los grandes oficios cortesanos la fuerza principal"13.

Junto a estos personajes, aparecen, hasta superar, con amplitud, el centenar, diversos personajes vinculados al servicio regio o estantes en la corte castellana ${ }^{14}$, de los

${ }^{12}$ Cf. Quintanilla Raso, M.C.: "La renovación nobiliaria en la Castilla bajomedieval. Entre el debate y la propuesta", en La nobleza peninsular en la Edad Media, León, 1999, pp. 257-295.

13 SuÁrez Fernández, L.: Nobleza y monarquía. Entendimiento y rivalidad. El proceso de la construcción de la Corona española, Madrid, 2005, p. 133.

${ }^{14}$ Entre los personajes citados a lo largo de la Relación de efectos se encuentran: maestre Abraham, tornero; Abrahem, hijo de Yuzaf Abenverga; frey Adán, fraile en el monasterio de Santa María la Real de Valdeiglesias; García Alfonso, repostero de los estrados de Enrique III; Rodrigo Alfonso, portugués; Rodrigo Alfonso de Oviedo; Mayr Alguadex, físico de Enrique III; Fernando Álvarez, hermano de García Álvarez de Toledo; Álvaro, camarero del infante Fernando de Antequera; Román Ambrosio; maestre Andrea, físico de Enrique III; Gómez de Baena, adalid; mosén Robín de Bracamonte; Pedro Carrillo de Toledo, criado; mosén Pere Cervelló; Teresa de Cisneros; Gonzalo Cuadrado, montero; Alonso de Dávalos, doncel de Enrique III; Ruy Díaz, hijo de Juan Hurtado de Mendoza; Alfonso Enríquez; Constanza Enríquez, mujer del infante Juan de Portugal; Diego de Estúñiga, doncel de Enrique III; Íñigo de Estúñiga, doncel de Enrique III; Miguel de Exea; Juan de Ezcaray, obispo de Cádiz y confesor de Enrique III; Alfonso Fernández, orfebre morisco; Alfonso Fernández, pellejero de Enrique III; Antón Fernández, orfebre morisco; Diego Fernández, alcaide de los donceles; Juan Fernández, hermano de Fernando Pérez de Castillejo; Juan Fernández, pellejero de Enrique III; Marcos Fernández, ballestero de maza de Enrique III; Pedro Fernández, bordador; Martín Fernández Cerón, alcalde mayor de Sevilla; Alfonso Fernández de Córdoba, repostero de estrados de capilla de Enrique III; Pedro Fernández de Córdoba, hombre de Diego González de Medina; Pedro Fernández de Guadalajara, monje del monasterio de Santa María de Guadalupe; Pedro Fernández de Robledo; Diego Fernández de Tapia, compañero de Martín López; Fernando, frutero; García Fernando, ballestero de maza de Enrique III; Antonia García, lavandera de Enrique III; Diego García, escudero de Enrique III y recaudador en el arzobispado de Sevilla; Fernando García, repostero de camas de Enrique III; Pedro García, ballestero de ballesta de Enrique III; Fernando García de Ciadoncha, repostero de estrados de Enrique III; Gómez García de Hoyos, caballerizo mayor de Enrique III; Gómez, hermano de Pedro Hurtado; Antón Gómez, contador; Juan Gómez de Baena, adalid; Alfonso González, maestresala de Catalina de Lancaster; Juan González de la Barrera, portugués; Vasco González de Ferro, portugués; Diego González de Medina, tesorero de la casa de la moneda de Burgos; Pedro González de Mendoza, mayordomo de Enrique III; Juan González de Moranza; Pedro González de Sevilla, ballestero de maza de Enrique III; Pedro González de Sevilla, escudero de caballo de Enrique III; Elvira de Guevara, mujer de Ruy López Dávalos; Diego Hurtado, hijo de Juan Hurtado de Mendoza y doncel de Enrique III; Pedro Hurtado; maestre Juan, físico de Enrique III; maestre Juan, juglar de Martín I de Aragón; maestre Juan, orfebre; Juanín, bordador inglés; Yusef Leví; Lobete, ayo de Roberto Sanluces; Fernando López de Riberes; Íñigo López, camarero de Enrique III; Juan López, escudero de Enrique III; Leonor López, bordadora; Martín López, compañero de Diego Fernández de Tapia; María, hija del infante Juan de Portugal y mujer de Martín Vázquez de Acuña; María, mujer de Juan Hurtado de Mendoza; Pedro Martínez; García Martínez, escudero de Juan González de Moranza; Fernán Martínez de Astudillo, repostero de capilla de Enrique III; Juan Martínez de Cáceres, beato; Diego Meléndez de Valdés el Mozo; Mendoza, hijo de Juan Hurtado de Mendoza y doncel de Enrique III; un mensajero del duque de Bretaña, sin nombre; Pedro de Monsalve, recaudador del obispado de Cuenca y Cartagena; Juanico de Oviedo, mozo de cámara de Enrique III; Rodrigo de Perea, doncel de Enrique III; Fernando Pérez de Castillejo, maestresala de Enrique III y hermano de Juan Fernández; Íñigo Pérez de Sevilla, orfebre; Diego Pérez Sarmiento, adelantado; Pifere, juglar de Martín I de Aragón; Juan Rodríguez de Guadalajara, lugarteniente de Gómez García de Hoyos; Alfonso Rodríguez, repostero de plata de Enrique III; Antón Rodríguez, escudero de Ruy López; Juan Rodríguez de Villarreal, tesorero de la casa de la moneda de Toledo; Benito Ruiz, ballestero de ballesta de Enrique III; Gonzalo Ruiz, acemilero mayor; Miguel Ruiz de Córdoba; Gonzalo Ruiz Molero; Juan de Sala, despensero de Enrique III; Bartolomé Sánchez, repostero de camas de Enrique III; Juan Sánchez 
que, en ocasiones, solo conocemos su nombre, por no ofrecer la Relación de efectos información alguna sobre el cargo ocupado, apellido o filiación familiar. Hecho que se podría poner en relación con la tendencia a aludir en diversos testimonios documentales gestados en la corte regia a los diferentes personajes de una forma familiar $\mathrm{y}$, en consecuencia, dando por sobreentendidas algunas informaciones, como apuntó Vicenç Beltrán para la corte de Isabel I de Castilla ${ }^{15}$.

\section{LA ITINERANCIA CORTESANA: DESDE BONILLA DE LA SIERRA HASTA TORDESILLAS}

La corte de Enrique III, siguiendo la tradicional itineracia regia ${ }^{16}$, transitó por distintas villas y ciudades de la Corona de Castilla, llevando al monarca desde Bonilla de la Sierra (Ávila), donde se encontraba el 27 de agosto de 1397, hasta Tordesillas (Valladolid), donde estaba el 18 de agosto de 1398, con estancias más o menos prolongadas en Salamanca, Madrid, Toledo y Toro. Las informaciones consignadas por la Relación de efectos permiten completar aquellas ofrecidas por Francisco de Asís Veas Arteseros en su Itinerario de Enrique III' ${ }^{17}$, basado en el estudio de los documentos expedidos por la cancillería regia. En este sentido, el interés de la Relación de efectos se encuentra en su potencialidad para conocer la situación del rey, por cuanto, como indica Veas Arteseros, "la emisión de un documento por la Cancillería regia no implicaba que el rey se hallara allí donde se databa el documento"18. Sin embargo, la Relación de efectos no constituye, en modo alguno, un instrumento fehaciente para conocer la ubicación del monarca, en tanto que, como veremos en algún caso, es posible saber o intuir que el camarero Pedro Fernández no siempre se encontraba junto a Enrique III, tal vez debido a los rápidos movimientos -que aconsejarían dejar estante parte de su corte, cámara incluida, en un lugar concreto- que se veía obligado a realizar el monarca, en buena medida como consecuencia directa del conflicto que

de la Bastida; Fernando Sánchez de Morana; Juan Sánchez de Salazar, despensero de las raciones de la casa de Enrique III; Juan Sánchez de Sevilla, contador mayor; Juan Sánchez de Úbeda; Pedro Sánchez, sastre; Roberto Sanluces, francés; Micer Solagraz Bocanegra; Juan Suárez de Sevilla; García de Valdés, criado de Enrique III; Juan Vázquez, arcediano de Sevilla; Gil Vicente?, portugués; Juan Ximénez de Barba, maestresala; Miguel Ximénez de Luxán; Juan de Zamora, ballestero de maza de Enrique III; Mosseh Aben-Zarzal, físico de Enrique III.

15 Beltrán, V.: "La reina, los poetas y el limosnero. La Corte literaria de Isabel la Católica", en Actas del VIII Congreso Internacional de la Asociación Hispánica de Literatura Medieval, Santander, 2000, pp. 353-364, pp. 357-359.

${ }^{16}$ Sobre la itinerancia cortesana son de interés los apuntes recogidos en Rodríguez LóPEZ, A.: "Viajar y gobernar: la monarquía itinerante", en Viajar en la Edad Media: XIX Semana de Estudios Medievales. Nájera, Logroño, 2009, pp. 381-404; GonzÁlez de Fauve, M.E.; Ramos, N.B.; Forteza, P.: "Los desplazamientos de la Corte castellana. Notas para su estudio", Estudios de Historia de España, 3 (1990), pp. 29-50; L'itinérance des cours (fin XIe siècle-milieu XVe siècle): un modèle ibérique? [en línea], e-Spania: Revue Électronique d>Études Hispaniques Médiévales, 8 (2009). URL: <http://e-spania. revues.org/18545> [fecha de consulta: 2013-05-20].

${ }^{17}$ Veas Arteseros, F. de A.: Itinerario de Enrique III, Murcia, 2003.

${ }^{18}$ Veas Arteseros, F. de A.: Itinerario..., p. 139, nota 5, con apuntes adicionales sobre este aspecto en Veas Arteseros, F. de A.: Itinerario..., pp. 12, 15-18. 
Castilla vivía con el rey de Portugal a lo largo de esos meses ${ }^{19}$. La confrontación entre la Relación de efectos y las aportaciones críticas ofrecidas por Veas Arteseros pone de manifiesto algunas divergencias claras sobre la ubicación del monarca, que, a su vez, permiten corregir algunos de los datos ofrecidos en el referido Itinerario para el año 1397: el 2 de septiembre, en Salamanca ${ }^{20}$ y no en Madrid $^{21}$; el 29 de octubre, quizá en algún punto entre Castronuño y Tordesillas ${ }^{22}$, mejor que en Madrigal ${ }^{23}$. Por el contrario, aunque la Relación de efectos sitúe al camarero Pedro Fernández a fines del mes de junio de 1398 en Toro, cabe pensar que el rey se encontraba fuera de la villa, pues Pero Fernández aludiría al hecho de que el rey había partido de allíín, a la vez que diversos documentos incluidos en el Itinerario ubican al monarca en Olmedo el 22 de junio ${ }^{25}$, el 5 de julio ${ }^{26}$ y el 4 de agosto ${ }^{27}$, coincidiendo precisamente con un período durante el cual es difícil de documentar la posición del rey ${ }^{28}$. Y, aunque quede en el campo de lo hipotético, cabe, al menos, sopesar la posibilidad de que Enrique III se encontrara a fines de mayo de ese año en Zamora -y no en Tordesillas, donde se encontraría su camarero, Pedro Fernández-, lugar adonde fue trasladado su sello personal ${ }^{29}$. En otros supuestos, en los que hay algunas diferencias no insalvables entre las informaciones proporcionadas por la Relación de efectos y el Itinerario, quizás nos encontraríamos ante movimientos fugaces del monarca, como el 14 de enero de 1398, cuando Veas Arteseros sitúe al rey en Móstoles $^{30}$, mientras la Relación de efectos localiza la cámara regia en Madrid ${ }^{31}$; o como el 15 de mayo de ese año, cuando el primero ubique al rey en Toro $^{32}$, mientras la Relación sitúa la cámara en Tordesillas ${ }^{33}$. Aunque la reina Catalina de Lancaster parece encontrarse en diversos momentos jun-

${ }^{19}$ Véase al respecto el apartado 6. El reflejo de los acontecimientos de la politica internacional entre los años 1397-1398: el fecho de la guerra de Portugal.

${ }^{20}$ El propio Itinerario sitúa a Enrique III el 1 de septiembre de 1397 en Salamanca, en ArTeSERos, F. de A.: Itinerario..., $\mathrm{n}^{\circ}$ 1.294. La Relación de efectos ubica al camarero Pedro Fernández, dos días después, el 3 de septiembre, en la misma ciudad, en Relación de efectos que Pedro Fernández recibía y entregaba de orden del Rey, Archivo General de Simancas (AGS), Patronato Real (PR), legajo (leg.) 29, documento (doc.) 28 [cit. en lo sucesivo como Relación...], fol. 500r.

${ }^{21}$ Veas Arteseros, F. de A.: Itinerario...., n ${ }^{\circ} 1.295$.

${ }^{22}$ El día 26 de octubre, el camarero Pedro Fernández se encontraba en Castronuño; el 30 de ese mes, ya en Tordesillas. Cf. Relación..., fols. 501r-501v.

${ }^{23}$ Veas Arteseros, F. de A.: Itinerario...., $\mathrm{n}^{\circ} 1.305$.

24 “en esta dicha villa [de Toro] miércoles xxvi días del dicho mes [junio], levó Fernán García de Çiadoncha, rrepostero de los estrados del Rey, quando el Rey partió de aqui de Toro", Relación...., (Toro, 1398-06-26), fol. 513r. [asiento tachado].

${ }^{25}$ Veas Arteseros, F. de A.: Itinerario...., $\mathrm{n}^{\circ} 1.360$.

26 Veas Arteseros, F. de A.: Itinerario...., $\mathrm{n}^{\circ} 1.362$.

${ }^{27}$ Veas Arteseros, F. de A.: Itinerario...., $\mathrm{n}^{\circ} 1.367$.

${ }^{28}$ Cf. Veas Arteseros, F. de A.: Itinerario..., p. 95.

${ }^{29}$ Relación..., (1398-05-29, Tordesillas), fol. 512r.

${ }^{30}$ Veas Arteseros, F. de A.: Itinerario...., $\mathrm{n}^{\circ} 1.317$.

${ }^{31}$ Relación..., fol. $507 \mathrm{v}$.

${ }^{32}$ Veas Arteseros, F. de A.: Itinerario...., $\mathrm{n}^{\circ} 1.355$.

${ }^{33}$ Aunque no hay ningún apunte relativo al día 15 de mayo de 1398, tenemos constancia de los referidos a los días 14 y 16 de mayo, los cuales sitúan la cámara en Tordesillas. Cf. Relación..., fols. 511r-511v. 
to al monarca, sabemos que ocasionalmente esta residía lejos de la corte, como hubo de suceder a fines de mayo de 1398, cuando la cámara regia se encontraba en Tordesillas, mientras que la reina estaba en Arévalo ${ }^{34}$.

Analizando la itinerancia del monarca durante la segunda mitad del año 1397 y la primera de 1398, es posible señalar que la corte se alejaba ocasionalmente durante estos meses, de una forma consciente, de lo que progresivamente sería considerado, desde el punto de vista de la percepción política de la Corona, como su espacio central, comprendido, a grandes rasgos, entre Burgos y Toledo ${ }^{35}$, al que se adscribirían, como nos informa la propia Crónica de Enrique III, ciudades como Segovia ${ }^{36}$. Cabe apuntar que buena parte de los movimientos de la corte durante los años 1397 y 1398 se encontrarían en estrecha relación con el referido conflicto castellano-portugués, que favoreció la presencia del monarca en las cercanías de la frontera noroccidental de la Corona. A inicios de agosto de 1397, el rey partía de Salamanca hacia Bonilla de la Sierra (Ávila), según sugiere Veas Arteseros, en relación con el hecho de que quizá "allí se estaban concentrando las tropas que se encargarían de taponar el previsible ataque luso por la zona cacereña" ${ }^{37}$. A fines del mes de agosto, Enrique III hubo de regresar a Salamanca, donde se encontraba el 31 de agosto. Allí hubo de permanecer, al menos, hasta el 22 de septiembre, cuando inició, pasando el 30 de septiembre por Fuentesaúco (Zamora), la marcha hacia Toro (Zamora), lugar en el cual se habría de encontrar ya el 4 de octubre, donde, en opinión de Veas Arteseros, "muy posiblemente se prolongase [su estancia] hasta que terminase de ordenar la disposición de las fuerzas que habrían de defender las posiciones por esa zona y, en caso necesario, de Galicia si se produjese el ataque portugués" ${ }^{\prime 8}$. Tras esta estancia en Toro, Enrique III inició su marcha, antes del 25 de octubre, hacia Madrid, pasando por la villa de Castronuño (Zamora), Tordesillas (Valladolid), Cantalapiedra (Salamanca), Madrigal de las Altas Torres (Ávila), Ávila y San Martín de Valdeiglesias (Madrid). El rey se encontraba en la villa de Madrid, al menos, desde el 29 de noviembre, para permanecer allí el mes de diciembre completo y casi la totalidad de enero de 1398. La estancia de la corte en el alcázar permitió abordar algunas reformas secundarias en la residencia, consistentes en la construcción de "dos escaleras que desçiendan de la torre a la cámara" ${ }^{39}$. Tareas específicas y menores que acabarían por integrarse en el

34 "Los quales dichos paños de seda el dicho señor Rey enbió a la dicha señora Reyna con Alfonso Gonzáles, su maestre de sala de la dicha señora Reyna, desde Oterdesillas a Arévalo, onde ella estava", Relación..., (1398-05-24, Tordesillas), fol. 511v.

${ }^{35}$ Cañas Gálvez, F. de P.: "La itinerancia de la corte de Castilla durante la primera mitad del siglo XV", e-Spania [en línea], 8 (2009). URL: <http://e-spania.revues.org/18829> [fecha de consulta: 201306-12].

36 "e ordenaron sus Tutores que fuese para Segovia, por quanto es buena cibdad; e está en medio del Regno", López de Ayala, P.: Crónica del rey don Enrique Tercero de Castilla e de León, en C. Rosell (ed.): Crónicas de los Reyes de Castilla, Madrid, 1953, 3 vols., vol. II, año 1392, cap. X, p. 197.

37 Veas Arteseros, F. de A.: Itinerario..., p. 91.

38 VeAs Arteseros, F. de A.: Itinerario..., p. 93.

${ }^{39}$ El registro presenta dificultades de lectura, fruto quizás de un error del escribano, siendo la lectura propuesta: “a la a 1 ca (sic.) cámara”, Relación..., (1397-12-21, Madrid), fol. 504v. 
ambicioso plan de reformas desarrolladas por el rey en su residencia madrileña ${ }^{40}$, que la tradición sitúa en $1405^{41}$, definirían un nuevo perfil palaciego para la antigua fortaleza. Después, a fines del mes de enero de 1398, Enrique III se dirigiría, pasando por Illescas (Toledo) y Torrijos (Toledo), hacia la ciudad de Toledo, donde se encontraba ya el 23 de febrero, y en la cual permaneció, al menos, hasta el 18 de marzo, cuando inició nuevamente el camino hacia el norte, siguiendo la ruta de Torrijos, Santa Olalla (Toledo) y Escalona (Toledo), hacia el monasterio de Santa María de Pelayos (cercanías de San Martín de Valdeiglesias), Ávila, Tordesillas, donde pasó parte del mes de mayo y junio, y Toro, en donde hubieron de transcurrir parte de los meses de junio, julio y agosto, y desde donde pudo tal vez realizar, en algún momento del verano, de una forma muy hipotética, algún movimiento hacia el territorio de Olmedo, como señalamos anteriormente. Fue en Toro donde quizá Enrique III hubo de celebrar Cortes, en cualquier caso, como señala Ana Arranz Guzmán, "como pronto, a mediados del mes de octubre, y nunca durante el verano"

En relación directa con la cuestión de la itinerancia regia, la Relación de efectos ofrece algunos apuntes contables de interés relativos a los traslados de la corte ${ }^{43}$, como el pago, realizado el 2 de noviembre de 1397, a "quatro carreteros" para el traslado de la cámara desde Tordesillas hasta Cantalapiedra ${ }^{44} \mathrm{y}$, el 11 del mismo mes, "a quatro azemileros" para el traslado de los bienes de la cámara desde Ávila a San Martín de

40 "que el mandó facer de nuevo, é se fizo en su tiempo, con las torres que en él están”, RoDRíGUEZ DE CuencA, J.: Sumario de los Reyes de España, ed. de E. de Llaguno Amirola, Valencia, 1971, p. 86; "fizo el alcáçar de Cartajena y el de Madrid, que se avía quemado en tienpo del rey don Enrique [II de Castilla], su avuelo", VAlera, D. de: Crónica abreviada de España, ed. de C. Moya García, Madrid, 2009, cap. 123, pp. 313-314. Sobre el alcázar de Madrid en el período trastámara véase GERARD, V.: De castillo a palacio. El alcázar de Madrid en el siglo XVI, Bilbao, 1984, pp. 15-17; BARBEITO, J.M.: El alcázar de Madrid, Madrid, 1992, pp. 3-7; Domínguez CASAs, R.: Arte y etiqueta de los Reyes Católicos. Artistas, residencias, jardines y bosques, Madrid, 1993, pp. 321-324.

41 “1405. El Rey Don Enrrique se atribuye por este tiempo el haverse puesto el Alcázar de Madrid en forma de Palacio levantando algunas torres que le hermoseasen", Real Academia de la Historia (RAH), 9/4080 (Olim Colección Pellicer, t. 26), fol. 86v-87r. De hecho, sabemos que dichas reformas se encontraban en curso en 1406, bajo la supervisión de Alfonso López: "De los VU, que yo mandé dar a Alonso Lópes, arçipreste de Segovia, provisor e vicario general en la Yglesia e Arçobispado de Toledo para ayuda de la costa que fizo estando en Madrid por mi serviçio e mandado en las lavores de los mis palaçios, dozyentos e çinquenta", Relación de los maravedís que recibió Juan Fernández de Villamuño recaudador mayor del obispado de Segovia de la renta de la chancillería de la tabla de los sellos del Rey del año 1406 (1406-07-22, Segovia), AGS, Cámara de Castilla (CC), Diversos (D), leg. 4, doc. 32, fol. 2r, encontrándose información sobre el desarrollo de las mismas en AGS, Estado-Castilla, leg. 1-12, docs. 8 y 10, editados en Nieto SoriA, J.M.: "La propaganda y la legitimación en los documentos", en Orígenes de la Monarquía Hispánica: propaganda y legitimación (ca. 1400-1520), Madrid, 1999, pp. 369-534, doc. 29, pp. 448-449.

42 Arranz Guzmán, A.: "En torno a las supuestas Cortes de San Esteban de Gormaz (1394) y de Toro (1398)", en Las Cortes de Castilla y León, 1188-1988, Valladolid, vol. I, pp. 333-340, pp. 336-337, con apuntes adicionales al respecto en Mitre Fernández, E.: "Las Cortes de Castilla y las relaciones exteriores en la Baja Edad Media: el modelo de Enrique III", Hispania: Revista española de Historia, 201 (1999), pp. 115-148, p. 132.

43 Sobre las cuestiones prácticas relativas a dichos traslados a fines del siglo XIV e inicios del siglo XV, pueden verse las notas recogidas en Veas Arteseros, F. de A.: Itinerario..., pp. 20-26; CAÑas GÁlvez, F. de P.: El itinerario de la Corte de Juan II de Castilla (1418-1454), Madrid, 2007, pp. 39-57.

44 Relación..., (1397-11-02, Cantalapiedra), fol. 501v. 
Valdeiglesias, haciendo uso de nueve acémilas y tres $\operatorname{asnos}^{45}$, siguiendo la costumbre de la casa real de Castilla de "disponer de pocas acémilas propias y alquilar las que se precisaran en cada caso o circunstancia" ${ }^{4}$. El número de acémilas empleado para el traslado de la cámara de Enrique III $^{47}$ muestra el patrimonio, todavía limitado, de la misma a fines del siglo XIV: significativamente inferior a las veinte acémilas empleadas en 1365 por Pedro I de Castilla (1350-1369) ${ }^{48}$ y ligeramente superior, en todo caso, a las empleadas por su antecesor inmediato en el trono Juan I de Castilla (13791390), cuando, por algún dato particular, sabemos que, en noviembre de 1379, fueron necesarias siete acémilas para llevar desde Burgos a Valladolid "algunas arcas de la nuestra cámara" "49. Dichas informaciones contrastarían vivamente, en cualquier caso, con el volumen alcanzado en la segunda mitad del siglo XV, cuando consta el empleo para el traslado de la cámara de Enrique IV de Castilla (1454-1474) de setenta a cien acémilas o de la cámara de Isabel I de Castilla (1474-1504) y sus hijas de unas ciento cincuenta acémilas ${ }^{50}$. Las propias necesidades para el traslado de los bienes del rey llevaron a la entrega, el 18 de noviembre de 1397, por parte de Diego González de Medina, tesorero de la casa de la moneda de Burgos, de seis acémilas "para traer su cámara"si.

${ }^{45}$ Relación..., (1397-11-11, San Martín de Valdeiglesias), fol. 502r.

${ }^{46}$ Ladero Quesada, M.Á.: "La Casa Real en la Baja Edad Media", Historia. Instituciones. Documentos, 25 (1998), pp. 327-350, p. 335, habiendo sido tal aspecto objeto de atención en las Cortes de Palencia de 1388: "Otrosy alo que nos dixieron que en las cortes de Segovia ordenamos e mandamos que non se tomasen azemilas nin carretas nin mulas nin otras bestias de siella nin de albarda, en ninguna çibdad nin villa delos nuestros rregnos, para nos nin para las nuestras cámaras nin de las rreynas nin de los infantes nuestros fijos nin para otro ninguno, aun que sobresta rrazon mostrasen nuestras cartas e alvalas; e por quanto non se guardava asý, que nos piden por merçed que mandásemos guardar lo que enlas dichas cortes fue ordenado en esta rrazón. Aesto rrespondemos que en caso que algunas cartas o alvalas avemos mandado dar o damos sobre esta rrazon, que toda via se dan con condiçión que pagen alquiler por las tales bestias o carretas; pero demas desto anos plaze de mandar guardar lo mas que se podiere que non tomen las tales bestias e carretas, por quel provecho dela tierra e nuestras çibdades e villas sea guardado", Cortes de Palencia (1388-10-02, Palencia) en Cortes de los antiguos reinos de León y de Castilla, Madrid, 1863, vol. II, pp. 417-418.

${ }^{47}$ Además de las informaciones antes referidas, por un documento relativo al año 1400 tocante a la villa de Cuéllar, sabemos que Enrique III se puso en contacto con el concejo para "que enbiasedes a mi serviçio diez carretas, e que de los maravedís de las monedas de la dicha villa e su tierra que yo mandé coger el dicho año, que les pagásedes sueldo de un mes a çierto preçio cada carreta", Enrique III de Castilla ordena al concejo de Cuéllar que pague la cantidad de 2.400 mrs. de que se había apropiado a cambio de enviar carretas que el rey necesitaba (1403-07-20, Burgos), Archivo Histórico Municipal de Cuéllar, sin sign., cit. en Ubieto Arteta, A.: Colección diplomática de Cuéllar, Segovia, 1961, doc. 171, pp. 395-396.

${ }^{48}$ Cf. Veas Arteseros, F. de A.: Itinerario..., p. 148, nota. 41.

49 Villalobos y Martínez-Pontrémuli, M.L. de: "Las gestiones hacendísticas de Diego López de Estúñiga, camarero de Juan I. Contribución al estudio de la economía y fiscalidad castellanas bajo los primeros Trastámaras", Hispania: Revista Española de Historia, 153 (1983), pp. 159-207, pp. 182-183, con referencia igualmente en CAÑAS GÁlVEZ, F. de P.: "La Casa de Juan I de Castilla: aspectos domésticos y ámbitos privados de la realeza castellana a finales del siglo XIV (ca. 1370-1390)", En la España Medieval, 34 (2011), pp. 133-180, p. 145.

${ }^{50}$ Ladero Quesada, M.Á.: "La Casa Real...”, p. 335; Ladero Quesada, M.Á.: “1462: un año en la vida de Enrique IV, rey de Castilla", En la España Medieval, 14 (1991), pp. 237-274 p. 239.

${ }^{51}$ Relación..., (1397-11-18, San Martín de Valdeiglesias), fol. 502v. 
La Relación de efectos permite identificar adicionalmente a dos cargos relacionados, en un sentido u otro, con la itinerancia del rey: su acemilero mayor, Gonzalo Ruiz $^{52}$, y su caballerizo mayor, Gómez García de Hoyos, quien hubo de ejercer el mismo cargo durante el reinado de Juan II $^{53}$, del cual actuaría, en 1398, como lugarteniente, Juan Rodríguez de Guadalajara ${ }^{54}$.

\section{LA CULTURA MATERIAL EN LA CORTE DE ENRIQUE III: EL PATRI- MONIO DE LA CÁMARA REGIA}

\subsection{INTRODUCCIÓN}

El patrimonio de la cámara -es decir, aquellos bienes muebles y moneda que se encontrarían en el entorno inmediato del monarca bajo el control del camarero mayor, los camareros reales u otros oficiales que gravitarían en el entorno de esta- de Enrique III hubo de tener como fundamento el conjunto de bienes legados por su padre, Juan I de Castilla ${ }^{55}$, incrementado por medio de distintas compras, percepción de rentas o derechos y donaciones, de las que se pueden documentar abundantes ejemplos a lo largo de la Relación de efectos. Dicho patrimonio de la cámara, al final de la vida de Enrique III, como era práctica habitual, hubo, en buena medida, de dispersarse ${ }^{56}$, quedando una parte del mismo, en concepto de herencia, una vez hecho el correspondiente inventario "de todas las joyas e otras cosas que están en las mis cámaras" por parte de los tutores, en manos de su hijo, Juan II de Castilla, bajo el control de sus camareros hasta que alcanzara la mayoría de edad ${ }^{57}$.

En este sentido, la Relación de efectos da cuenta de una parte específica de este patrimonio de la cámara, aquel bajo la custodia directa del camarero Pedro Fernández, que correspondería a una suerte de tesoro de la cámara regia pues, junto a este conjunto de bienes bajo control de Pedro Fernández, núcleo patrimonial de la cámara,

${ }^{52}$ Relación..., (1397-09-03, Salamanca), fol. 500r, con referencia a dicho cargo en la corte castellana bajomedieval en SalazAr y Acha, J. de: La Casa del rey de Castilla y León en la Edad Media, Madrid, 2000, pp. 311-312; Cañas Gálvez, F. de P.: El itinerario..., pp. 43-44; Domínguez Casas, R.: Arte y etiqueta de los Reyes Católicos. Artistas, residencias, jardines y bosques, Madrid, 1993, pp. $242-243$.

53 Salazar y Acha, J. de: La Casa..., pp. 309, 531; Cañas GÁlvez, F. de P.: El itinerario..., pp. 45-47.

${ }^{54}$ Relación..., (1398-05-28, Tordesillas), fol. 512r, con referencia a dicho cargo en la corte castellana bajomedieval en SAlazar y Acha, J. de: La Casa..., pp. 308-311; CAÑAs Gálvez, F. de P.: El itinerario..., pp. 45-47; Domínguez CASAs, R.: Arte y etiqueta..., pp. 240-242.

55 Testamento de Juan I (1385-07-21, Celorico da Beira) en P. López de Ayala: Crónica de don Enrique Tercero..., cap. 1392, cap. VI, pp. 191, 193.

56 Por las disposiciones testamentarias de Enrique III, sabemos de la entrega, al menos, parcial, de los bienes del rey "que están en la mi cámara" para mandas piadosas o descargos. Testamento de Enrique III (1406-12-24, Toledo) en García de Santa María, A.: Crónica de Juan II de Castilla, ed. de J. de M. Carriazo y Arroquia, Madrid, 1982, cap. VI, p. 28.

57 Testamento de Enrique III (1406-12-24, Toledo) en García de SANTA MaríA, A.: Crónica de Juan II..., cap. VI, p. 36, con referencia a la condición de Juan II de "heredero universal en todos mis Reynos e señoríos, e en todos los dichos mis bienes, ansí muebles como raízes" en Testamento de Enrique III (1406-12-24, Toledo) en García de Santa María, A.: Crónica de Juan II..., cap. VI, p. 31. 
existirían diversos bienes custodiados por otros oficiales de la corte (reposteros de la capilla real, cámara de los paños, reposteros de estrados, camarero mayor, etc.).

\subsection{LA INDUMENTARIA CORTESANA}

Los testimonios iconográficos documentados de Enrique III y de su círculo cortesano $0^{58}$ muestran, de una forma esquemática pero veraz, las modas en el ámbito de la indumentaria civil a fines del trescientos en la Corona de Castilla. La Relación de efectos permite, en esta dirección, completar diversos aspectos sobre las tipologías, materiales o técnicas ornamentales empleadas en la confección de la indumentaria del rey y, por extensión, de su círculo personal más cercano ${ }^{59}$.

Así, la Relación de efectos ofrece un catálogo detallado de las prendas propias del vestir cortesano de fines del siglo XIV ${ }^{60}$ : prendas interiores o semiinteriores (camisón $^{61}$, jubón y alhame), prendas de vestir a cuerpo (jaqueta, laudel), traje de encima

${ }^{58}$ Instituto Valencia de Don Juan, sign. A. 9.6; Archivo de la Catedral de Sevilla (ACS), sección IX, carpeta 116, $\mathrm{n}^{\circ}$ 42; Archivo Histórico Nacional (AHN), Sigilografía, armario 8, caja 122, $\mathrm{n}^{\circ} 7$. Algunos apuntes y reproducción de los mismos en ANDRÉs, G. de: "Dos retratos auténticos. Enrique III de Castilla y Sancho de Rojas, arzobispo de Toledo", Goya: Revista de Arte, 156 (1980), pp. 324-327; CHAO CASTRO, D.: Iconografía regia en la Castilla de los Trastámara, tesis doctoral inédita leída en el Departamento de Historia del Arte. Facultad de Geografía e Historia. Universidad de Santiago de Compostela, Santiago de Compostela, 2005, pp. 50, 240-242; Borrero Fernández, M.: Sevilla, ciudad de privilegios: escritura y poder a través del privilegio rodado, Sevilla, 1995, pp. 29, 36, 491; PAVÓN CASAR, F.: La imagen de la realeza castellana bajomedieval en los documentos y manuscritos, tesis doctoral inédita leída en el Departamento de Ciencias y Técnicas Historiográficas. Facultad de Geografía e Historia. Universidad Complutense de Madrid, Madrid, 2009, pp. 474-475, 484-485. Paralelamente a la figura de Enrique III, se pueden encontrar buenos ejemplos al respecto en dos testimonios iconográficos relativos a Pero López de Ayala en LóPez de Ayala, P., Morales de San Gregorio Lib. XVIII-XXVI, Biblioteca Nacional de España (BNE), Manuscritos, Vitr/17/6, fol. 1r, con un análisis de la misma en Yarza LuACES, J.: "La nobleza hispana y los libros iluminados (1400-1470). Corona de Castilla", en La Memoria de los libros: estudios sobre la historia del escrito y de la lectura en España y América, Salamanca, 2004, vol. I, pp. 17-66, pp. 42-43; Retablo y frontal del monasterio de San Juan de Quejana, Álava (1396), Art Institute of Chicago, $\mathrm{n}^{\circ}$ cat. 1928.817, con análisis del mismo en Melero Moneo, M.L.: "Retablo y frontal del convento de San Juan de Quejana en Álava (1396)", Locus Amoenus, 5 (2000), pp. 33-51, p. 46.

${ }^{59}$ Dentro de los asientos relativos a la confección de prendas de vestir, destacan las confeccionadas para el rey, seguidas de aquellas elaboradas para ser entregadas, en concepto de merced, a miembros permanentes o estantes temporalmente en su corte.

${ }^{60}$ Una orientación general sobre las mismas en BERnIS MADRAZO, C.: Indumentaria medieval española, Madrid, 1956; Puigvert Ocal, A.: "El léxico de la indumentaria en el Cancionero de Baena", Boletín de la Real Academia Española, 241 (1987), pp. 171-206, pp. 185-204, con apuntes para un período posterior, aunque con algunas referencias de interés al respecto, en Bernis Madrazo, C.: Trajes y modas en la España de los Reyes Católicos, Madrid, 1978-79, 2 vols.; GonzÁlez Marrero, M. del C.: La Casa de Isabel la Católica. Espacios domésticos y vida cotidiana, Ávila, 2004, pp. 264-300. Para la clasificación tipológica de las prendas, seguimos las orientaciones presentadas en MarTíNEZ MARTínEZ, M.: "Indumentaria y sociedad medievales (ss. XIII-XV)", En la España Medieval, 26 (2003), pp. 35-59, p. 48.

${ }^{61}$ Aunque, al menos, desde el siglo XV el término camisón aludiría a la "camisa de noche", siguiendo a Fernández de Oviedo, G.: Libro de la Cámara Real del príncipe don Juan, ed. de S. Fabregat Barrios, Valencia, 2006, p. 96 y Díaz De Games, G.: El Victorial, ed. de R. Beltrán Llavador, Madrid, 2000, cap. 39, p. 283, en línea con el aporte crítico de Alonso, M.: Diccionario medieval español. Desde las Glosas Emilianenses y Silenses ( $\mathrm{s}$. X) hasta el siglo XV, Salamanca, 1986, t. I, p. 599, de forma adicional, esta parece que pudo ser una prenda interior, similar a la camisa, aunque de mayor longitud, 
y sobretodo (gramalla, hopa, jaque, balandrán, mantón, sobreveste y, tal vez, el cosete), tocados (capirote) y calzado y prendas para las piernas (escarpines, polainas, borceguíes, calzas). En algún caso, es posible documentar la confección particular de mangas -en aceituní o arabí, forradas en cendal o en escarlata, que podrían ir, a su vez, a juego con las polainas, como se puede documentar por algún caso concreto ${ }^{62}-\mathrm{o}$ de collares para los vestidos - confeccionados en hilo de oro y seda ${ }^{63}$.

Entre las telas citadas en la Relación de efectos abundan los tejidos realizados en lana (escarlata, mostrevillén, bruneta, chalón, florentín y el realizado en pelo de camello, de nombre chamelote), seda (tapete raso o velludo/velloso, con frecuencia referido como de Toris ${ }^{64}$, aceituní, baldoque, imperial, camocán o paño de seda morisca, ricomas, paño de damasquines, zarzahán), algodón (arabí) y lino (lienzo delgado, lienzo de Remes, lienzo de sobrepelliz), así como aquellos otros tejidos que podrían estar realizados indistintamente en un material u otro, como el cendal ${ }^{65}$ (seda o lino), el satín (preferentemente en seda, pero también en lana o algodón) o el fustán (referido, en sus diversas modalidades, como fustán de seda, fustán de algodón y fustán real) ${ }^{66}$. Entre estos paños, como nos da cuenta, por alguna información puntual, la propia Relación de efectos, los imperiales, ricomas y baldoques tenían la condición de paños de oro, por estar confeccionados en seda entretejida con hilo de oro ${ }^{67}$, a los que se podrían sumar, al menos en esta línea, otras dos clases de tejidos: el savastro, realizado comúnmente con oro ${ }^{68}$, y las variedades ricas de paños, como un "damasco roxo rico con oro" 69 un "zarzahán rrico"70.

Por sus especiales características, cabría llamar la atención sobre un grupo de telas que genéricamente podríamos denominar como andalusíes y orientales ${ }^{71}$ : el baldoque,

como parece sugerir Juan de Sevilla a fines del siglo XIV, al señalar "que en primavera visten camisones y camisas, y, encima, un jubón de una libra de algodón”, Aviñón, J. de: Sevillana medicina, ed. De José Mondéjar, Madrid, 2000, cap. VII, p. 123.

${ }^{62}$ Relación..., (1398-04-28, Ávila), fol. 511r.

${ }^{63}$ Relación..., (1398-07-08, Toro), fol. 513v.

${ }^{64}$ En un caso particular, sabemos que este tapete se encontraba decorado con "lavores de seda verde e blanca e colorada", Relación... (1397-09-12, Salamanca), fol. 500r.

${ }^{65}$ Además del cendal propiamente dicho, en la Relación de efectos se cita, en una ocasión, una pieza de "çendal terzinel", empleada como forro de una hopa. Relación..., (1398-06-25, Toro), fol. 513r.

${ }^{66}$ Algunas informaciones de interés sobre las características de estos tejidos en Alfau de Solalinde, J.: Nomenclatura de los tejidos españoles del siglo XIII, Madrid, 1969; DÁvILA Corona, R.M.; DurÁn Pujol, M.; García Fernández, M.: Diccionario histórico de telas y tejidos: castellano-catalán, Valladolid, 2004; Martínez Meléndez, M. del C.: Los nombres de tejidos en castellano medieval, Granada, 1989; González Marrero, M. del C.: La Casa ..., pp. 218-250; Puigvert Ocal, A.: "El léxico de la indumentaria...”, pp. 172-184.

${ }^{67}$ Véase sobre este aspecto véase el asiento Relación..., (1397-11-02, Cantalapiedra), fol. 501v. De hecho, en el caso del baldoque, ocasionalmente se hace uso de la expresión baldoque brocado con oro en Relación..., (1398-01-12, Madrid), fol. 507v; Relación..., (1398-02-27, Toledo), fol. 509r.

${ }^{68}$ El savastro aparece referido en la Relación como paño de oro o con oro o, más raramente, con plata. Relación..., fols. 506v-508r, 509r-512r, con algunas notas sobre este en MARTínez Meléndez, M. del C.: Los nombres..., pp. 541-542.

${ }^{69}$ Relación..., (1398-04-22, Ávila), fol. 510v.

${ }^{70}$ Relación..., (1398-06-23, Toro), fol. 512v.

${ }^{71}$ Algunas notas sobre estas telas en Partearroyo Lacaba, C.: "Tejidos almorávides y almohades", en Al-Andalus. Las artes islámicas en España, Madrid-Nueva York, 1992, pp. 104-113; Partearro- 
con su característica decoración figurada o epigráfica bordada en oro ${ }^{72}$; el arabí, con labores de oro y seda de colores ${ }^{73}$; y el camocán o paño de seda morisca, decorado en sus extremos con cenefas confeccionadas con hilo de oro ${ }^{74}$.

Junto a estos paños de oro y tejidos andalusíes y orientales es posible destacar la decoración emblemática de una hopa larga confeccionada para el rey con zarzahán "rrico a castillos e leones" 75 . Dicha decoración con las armerías reales, dispuesta seguramente en damero -composición para la que se ha apuntado un origen mudéjar ${ }^{76}$, seguiría pautas decorativas documentadas en algunas prendas del vestidor regio, al menos, desde mediados del siglo XIII, durante los reinados de Alfonso $\mathrm{X}^{77}$, Alfonso $\mathrm{XI}^{78}$ y Juan I de Castilla ${ }^{79}$.

Conforme a lo señalado por la Relación de efectos, las prendas podrían estar ocasionalmente adornadas haciendo uso de diversas fórmulas ornamentales: motivos fi-

yo Lacaba, C.: "Tejidos andalusíes", Artigrama, 22 (2007), pp. 371-419; Navarro Espinach, G.: "El comercio de telas entre Oriente y Occidente (1190-1340)", en Vestiduras ricas. El monasterio de Las Huelgas y su época (1170-1340), Madrid, 2005, pp. 89-106; CABrera LAFUente, A.: "Telas hispanomusulmanas: Siglos X-XIII”, en V Semana de Estudios Medievales, Logroño, 1995, pp. 199-208; PéreZ Higuera, T.: Objetos e imágenes de Al-Andalus, Madrid, 1994, pp. 17-20, 86-100.

72 "las dos con unas lavores de oro, en manera de leones (...) et las otras dos con unas lavores de oro, en manera de árvoles e canes, et están en los árvoles, en cada uno, una fegura de çiervo de seda blanca", Relación..., (1397-12-25, Madrid), fol. 505r; "el canpo colorado, con unas lavores de oro a manera de leones", Relación..., (1398-01-01, Madrid), fol. 506v; "el canpo blanco con unas lavores de letras moriscas de seda colorada", Relación..., (1398-04-04, monasterio de Sta. M de Pelayos), fol. 510v; "el canpo colorado con unas lavores de oro, en manera de árvuoles e lebreres, e con unas lavores de seda blanca en manera de barrcos e çiervos e çisnes", Relación..., (1398-05-24, Tordesillas), fol. 511v.

73 "con unas lavores de oro et de seda de colores", Relación..., (1397-12-19, Madrid), fol. 504v; "con unas lavores de oro e con otras lavores de seda de colores", Relación..., (1397-12-29, Madrid), fol. 505v; "de arabý azul brocado con oro e con unas lavores, que está senbrad $a$ toda la dicha pieça de lavores de oro e de seda de colores", Relación..., (1398-02-02, Illescas), fol. 508r.

74 "et la otra, con unas açenefas en los cabos", Relación..., (1398-07-05, Toro), fol. 513r; "una pieça de paño de seda verde morisca, et tiene dos açenefas de oro a los cabos", Relación... (1398-07-08, Toro), fol. $513 \mathrm{v}$.

${ }^{75}$ Relación..., (1398-06-23, Toro), fol. 512v.

${ }^{76}$ Sobre el "valor decorativo de los emblemas heráldicos" y su inspiración a partir de "modelos sugeridos por el gusto mudéjar" o "pautas repetitivas propias del gusto mudéjar", véase MENÉNDEZ PIDAL, F.: Los emblemas heráldicos. Una interpretación histórica, Madrid, 1993, pp. 84-86; MeNÉNDEz PIDAL, F.: El escudo de España, Madrid, 2004, pp. 85-86, con referencia -en relación específica con el manto de Fernando III (Real Armería) y la capa del arzobispo don Sancho (catedral de Toledo)- a su posible producción en "talleres mudéjares al servicio de los reinos de Castilla y León" en Pérez HiguerA, T.: Objetos e imágenes..., Madrid, 1994, pp. 95-96.

77 Menéndez Pidal, G.: La España del siglo XIII leída en imágenes, Madrid, 1986, p. 37; García Cuadrado, A.: Las Cantigas: El Códice de Florencia, Murcia, 1993, p. 81.

78 "Et el dia que se ovo de coronar vestió sus paños reales labrados de oro et de plata a señales de castiellos et de leones", Crónica del rey don Alfonso el Onceno, en C. Rosell (ed.): Crónicas..., vol. I, cap. C, p. 235.

79 “(...) mandamos una vestimenta con sus almáticas, e su casulla, e todos sus aparejos tegidos de paño de peso, con nuestras armas de castillos e leones e quinas; e mas otra vestimenta con sus almáticas de seda tegida con sus castillos e leones e quinas (...) E mandamos mas a la dicha Iglesia de Toledo doce capas de seda tegidas con nuestras armas de castillos e leones e quinas, con sus cenefas ricas", Testamento de Juan I (1385-07-21, Celorico da Beira) en P. López de Ayala: Crónica del rey don Enrique Tercero..., año 1392, cap. VI, p. 187. 
gurativos -cruces, figuras zoomórficas, motivos vegetales (folajes), etc.- bordados sobre las telas en seda de colores o en hilo de oro o plata, decorando zonas específicas, como las mangas; aljófar, trazando o no motivos figurados, para la decoración de zonas como "arrededor de ençima de las mangas"; cordones de seda; cascabeles y chapillas con letras realizadas en metal, referidas como "chapillas, en que yva en cada chapilla una letra", "unas rrosillas con unas letras", "cascacaveles con sus chapillas, todo dorado" o "chapillas, que tiene cada una hun cascavel, todo de plata dorado" ${ }^{80}$; piezas de tela, generalmente dispuestas en una vanda o en vanda en hopas, balandranes y capirotes, confeccionadas con el referido savastro o cintas de oro anchas e angostas, considerándose como ancha, por alguna información puntual, aquella que tuviera, al menos, "tres dedos"

La Relación de efectos ofrece igualmente frecuentes muestras del interés por forrar (aforrar) y perfilar (en perfiles, con los perfiles) diversas prendas (cosetes, hopas, balandranes) con pieles. Uso que no solo tenía como fin, en palabras de Íñigo Mugueta Moreno y Merche Osés Urricelqui, "protegerse de los fríos inviernos, sino que además constituían un signo de riqueza y de poder para las personas que las poseían"\$2, una vez superadas las precauciones que imponía la percepción de las pieles como símbolo del mundo incivilizado, para convertirse en un elemento cortesano de ostentación a partir fundamentalmente del siglo XIV ${ }^{83}$, aunque, al menos en el caso castellano, la corte alfonsí de la segunda mitad del siglo XIII ofrezca ya alguna muestra de tales usos ${ }^{84}$. Este interés por el empleo de pieles se manifestó en la presencia de pellejeros (peligeros), es decir, de los profesionales encargados de "aforrar ropas de pellejos" ${ }^{85}$, formando parte de la corte. Dentro de las funciones de estos pellejeros, se encontraba el tratamiento de las pieles para hacer los forros de pieles o peñas (en función del origen de la piel, denominadas como peñas veras, peñas grises, peñas

${ }^{80}$ Conocemos, en algún caso, la posición aproximada de estos cascabeles: "et está de la çinta arriba e por las mangas senbrado todo de unas chapillas, que tiene cada una hun cascavel", Relación..., (139710-11, Toro), fol. 501r. Sobre la moda internacional de disponer elementos metálicos, característica de fines del siglo XIV y la primera mitad del siglo XV, aunque no privativa de este período, como muestra el uso, como elemento decorativo, de "plaquitas metálicas repujadas" en el siglo XIII castellano, véase: Piponnier, F.; Mane, P.: Dress in the Middle Ages, New Haven-Londres, 1997, p. 73; Egan, G.; Pritchard, F.: Dress Accessories, c. 1150- c. 1450. Medieval Finds from Excavations in London, Woodbridge, 2002, pp. 336-341, con apuntes sobre las referidas placas metálicas repujadas en FERNÁNDEZ GonZÁlez, E.: "Que los reyes vestiessen paños de seda, con oro, e con piedras preciosas. Indumentarias ricas en la Península Ibérica (1180-1300): entre la tradición islámica y el Occidente cristiano", en El legado de Al-Andalus. El arte andalusí en los reinos de León y Castilla durante la Edad Media, Valladolid, 2007, pp. 365-408, p. 374.

${ }^{81}$ Relación..., (1398-07- ¿15?, Toro), fol. 513v.

${ }^{82}$ Mugueta Moreno, Í.; Osés Urricelqui, M.: "Gastos suntuarios de Juana II y Felipe de Evreux (1328-1330)", en Grupos sociales en la historia de Navarra: relaciones y derechos, Pamplona, 2002, t. 1, pp. 107-118, p. 110.

${ }^{83}$ Piponnier, F.; Mane, P.: Dress..., pp. 23-24.

${ }^{84}$ Fernández GonzÁlez, E.: "Que los reyes...", p. 374; Descalzo, A.: "El vestido entre 1170 y 1340 en el Panteón Real de las Huelgas", en Vestiduras ricas. El monasterio de Las Huelgas y su época (11701340), Madrid, 2005, pp. 107-118, p. 108.

${ }^{85}$ Covarrubias Orozco, S. de: Tesoro de la lengua castellana o española, Madrid, 1611, fol. 583v, con algún apunte adicional en Nieto Jiménez, L.; Alvar Ezquerra, M.: Nuevo tesoro lexicográfico del español (s. XIV-1726), Madrid, 2007, vol. VIII, p. 7520. 
armiñas, etc.), confeccionadas con veros -piel de marta cebellina-, armiños -piel del animal del mismo nombre-, martas - piel del animal de este nombre-, esqueroles - piel de ardilla- y grises - piel del petigrís, una tipología específica de ardilla criada en Siberia. En ocasiones, las prendas podían encontrarse forradas en telas, frecuentemente cendal, aunque sea posible documentar anecdóticamente el uso de bruneta, de lienzo blanco, de paño pardillo de lo de viaje, de paño de escarlata o de paño de sestre.

Las prendas eran monócromas, es decir, realizadas íntegramente en telas de un mismo color, destacando, dentro de la gama cromática, el rojo (colorado, con referencia ocasional al teñido en grana), definido por Michel Pastoureau como "el color más noble en la Edad Media" ${ }^{8}$; seguido del azul y el verde; a más distancia, del blanco, el negro (preto) y el color rojizo conocido como roxo, que, como señala José Corominas, "debió designar un matiz de color especial"\$7; y, por último, como colores marginales o secundarios, el amarillo, el violáceo oscuro (violete escuro), el pardo (pardillo), el castaño (tenado ${ }^{88} \mathrm{y}$ el aceitunado oscuro (azeytunado escuro). En palabras de Juan Vicente García Mansilla, "colores oscuros, brillantes, y sobre todo caros, por las raras sustancias tintóreas que se necesitaban para conseguirlos (....) que contrastaban a la perfección con los brillos del brocado de oro o de las joyas que se superponían a las prendas" ${ }^{99}$ y, a su vez, como indica Cristina Sigüenza Pelarda, con el cromatismo de los vestidos de las clases más humildes, que emplearían colores neutros o pardos ${ }^{90}$. No obstante, estos colores pudieron ser, en algún caso particular, presentados de una forma alterna, dando lugar a prendas bicolores, como quizás sucedería en el laudel "barrado de colorado e azul", en el que entrarían "tres varas e tres quartas de satín colorado, e otras tres varas e tres quartas de satín azul", entregado a Fernando Álvarez, hermano de García Álvarez de Toledo'.

Atendiendo a esta serie de aspectos, el proceso de promoción de la figura regia y de la corte en torno al vestido se realizó fundamentalmente a través de dos estrategias. En primer lugar, la tendencia a adoptar las nociones de magnificencia y ostentación como uno de los fundamentos de la representación regia, reforzada por una legislación dirigida a definir usos exclusivos de ciertos materiales o colores, reservados para

${ }^{86}$ Pastoureau, M.: Diccionario de los colores, Barcelona, 2013, p. 261.

87 De él señala Sebastián de Covarrubias que "entre roxo y bermejo hazemos diferencia, porque el roxo es una color dorada; la bermeja es más encendida", Covarrubias Orozco, S. de: Tesoro..., fol. 131r, con diversos apuntes al respecto en Corominas, J.; PASCUAL, J.A.: Diccionario crítico etimológico castellano e hispánico, Madrid, 1997, $3^{\text {a }}$ reimpresión, vol. V, pp. 54-55; Nieto Jiménez, L.; Alvar EzQuerra, M.: Nuevo tesoro..., t. 9, pp. 8571-8572; TERREROS Y PANDO, E. de: Diccionario castellano con las voces de Ciencia y Artes, Madrid, 1788, t. III, p. 388.

${ }^{88}$ Onofre, P.: Thesaurus puerilis, Barcelona, 1684, p. 399; Nieto Jiménez, L.; Alvar Ezquerra, M.: Nuevo tesoro..., t. 10, p. 9274.

${ }^{89}$ García Marsilla, J.V.: "Vestir el poder. Indumentaria e imagen en las cortes de Alfonso El Magnánimo y María de Castilla", Res Publica: Revista de Filosofia Política, 18 (2007), pp. 353-374, p. 361.

${ }^{90}$ Sigüenza Pelarda, C.: "La vida cotidiana en la Edad Media: la moda en el vestir en la pintura gótica", en La vida cotidiana en la Edad Media: VIII Semana de Estudios Medievales: Nájera, del 4 al 8 de agosto de 1997, Logroño, 1998, pp. 353-368, p. 361.

${ }^{91}$ Relación..., (1397-09-18, Salamanca), fol. 500v. 
la elite política de la Corona ${ }^{92}$. En este sentido, desde tal perspectiva, se hubo de hacer uso preferentemente de tejidos ricos, especialmente de aquellos confeccionados en seda u oro, o importados, como -si es que, en algún caso, su denominación no hacía ya referencia a su procedencia, sino al tipo de tejido, al margen de dónde hubiera sido confeccionado- la escarlata de Londres, la de Duai (Doay), la de Malinas o la de Bruselas, el paño de Ypres (Ypre), el paño de florentín, el tapete de Tabriz (Toris), el lienzo de Reims (Remes ${ }^{93}$ ), el paño y escarlata de Montivilliers (Mostrevillén) o el paño de Châlons-sur-Marne (Chalón), las cuales remiten a producciones pañeras tanto de origen europeo como andalusí u oriental, importadas estas últimas, como tenemos constancia en algún caso puntual para el reinado de Enrique III, a través de los venecianos ${ }^{94}$. Aunque la Relación de efectos no aporte informaciones sistemáticas sobre precios, conocemos el de algunos paños o pieles como, por ejemplo: dos piezas de ricomas, 71,5 florines ${ }^{95}$; una pieza de baldoque con oro, 55 florines $^{96}$; una pieza de mostrevillén, 900 mrs. ${ }^{97}$; cada gris, 3 mrs..$^{98}$; cada esquerol, 2 mrs. ${ }^{99}$; cada onza de oro, 40 mrs. ${ }^{100}$; cada onza de cinta de oro, $40 \mathrm{mrs} .{ }^{101}$; o cada onza de seda, 15 mrs. ${ }^{102}$.

${ }^{92}$ Un panorama general sobre esta serie de aspectos en GonZÁLEZ ArCE, J.D.: Apariencia y poder: la legislación suntuaria castellana en los siglos XIII-XV, Jaén, 1998; Martínez MartíneZ, M.: "Indumentaria y sociedad...”, pp. 53-59; GonzÁlez Marrero, Ma del C.: La Casa..., pp. 255-264, con referencias para el Occidente medieval en Piponnier, F.; Mane, P.: Dress..., pp. 83-86, con una aproximación sobre el papel del color desde una perspectiva de la representación política en GonZÁLEZ ARCE, J.D.: "El color como atributo simbólico del poder (Castilla en la Baja Edad Media)", Cuadernos de Arte e Iconografia, 6:11 (1993), pp. 103-108.

${ }^{93}$ Sobre dicha identificación véase Alfau de Solalinde, J.: Nomenclatura..., pp. 159-160.

94 Así parece sugerirlo una carta, de año desconocido, aunque probablemente escrita en torno a 1400-1402, en atención a la referencia al "grand daño que avía fecho el Taborlán en tierra de Siria", hecho histórico que tuvo lugar en 1400-1401, y la fórmula en el protocolo final "Dios (...) vos dé vitoria contra todos vuestros aversarios", en posible alusión al conflicto frente a Portugal entre 1396-1402, relativa a la adquisición de algunos productos transportados por las galeras venecianas: "Señor, sepa la vuestra merçed que resçebý vuestra carta que la vuestra merçed me enbió con Pero Estévanez de la vuestra cámara por la qual la vuestra merçed me enbió dezir que avíades sabido que agora avían de venir algunas galeas de Venegia e que la vuestra merçed enbiava mandar a Ruy Gonçález que llegase allá e conprase algunos paños de oro e de seda e otras cosas que vuestra merçed avía menester segund vería por un memorial que la vuestra merçed me enbió e, que por ventura Ruy Gonçalez non terrnía cunplimiento para pagar las dichas cosas, enbiastes me mandar que sy él me requeriese sobre ello que le pagase la meytad de lo que costasen los dichos paños e cosas por que él vos lo pudiese luego enbiar con el dicho Pero Estévanez (...)", Carta de Bernal González, escribano real, al monarca sobre la compra de mercancías de Venecia (0000-06-26), AGS, Estado-Castilla, leg. 1-1-2, fol. 153. La carta señala específicamente dentro de los productos, "otras joyas", los "axaropes e espeçias" y "los çendales", (...)", Carta de Bernal González, escribano real, al monarca sobre la compra de mercancías de Venecia (0000-0626), AGS, Estado-Castilla, leg. 1-1-2, fol. 153.

${ }^{95}$ Relación..., (1397-11-02, Cantalapiedra), fol. 501v.

96 Relación..., (1397-11-02, Cantalapiedra), fol. 501v.

${ }^{97}$ Relación..., (1397-12-18, Madrid), fol. 504v.

${ }^{98}$ Relación..., (1397-11-02, Cantalapiedra), fol. 501v; Relación..., (1398-02-12, Illescas), fol. 508v; Relación..., (1397-10-30, Tordesillas), fol. 501v.

${ }^{99}$ Relación..., (1398-06-23, Toro), fol. 513r.

${ }^{100}$ Relación..., (1397-12-17, Madrid), fol. 504v.

101 Relación..., (1397-10-30, Tordesillas), fol. 501v.

102 Relación..., (1397-12-17, Madrid), fol. 504v. 
En segundo lugar, el interés -buscando mantener una adecuada decencia y decoro entre los servidores del entorno regio- por la distribución de libreas entre los oficiales de la corte real ${ }^{103}$, actuando, junto a tales distribuciones, el regalo y el intercambio de paños y vestidos como instrumento de interés para establecer y reforzar los vínculos políticos y sociales ${ }^{104}$.

Un primer acercamiento a la Relación de efectos permite intuir una amplia presencia en la corte de Enrique III de las modas internacionales europeas de cuño francoborgoñón, conforme al modelo cristalizado en torno a 1370, aunque mostrando, a su vez, un amplio interés por las telas hispano-musulmanas y orientales, en continuidad con las pautas de consumo de la corte de Juan I de Castilla ${ }^{105}$. Dicho interés por estas telas se hubo de concretar en la preferencia de Enrique III por los ya referidos baldoques, arabíes, zarzahanes, aceituníes, camocanes o paños de seda morisca ${ }^{106} \mathrm{y}$ los imperiales, puestos al servicio, salvo alguna excepción ${ }^{107}$, de las referidas modas internacionales. Estas modas, marcadas por la influencia del atavío de origen militar y por la amplia presencia, como prenda emblemática del momento, de la hopa u hopalanda ${ }^{108}$, se caracterizarían, como ha señalado Carmen Bernis, por la "busca de un estilo de contrastes, creando siluetas recortadas junto a siluetas ampulosas, subrayan-

103 "Otrosí, ordeno e mando que den vestuario a todos los de la casa del dicho prínçipe quando fuere Rey, ansí a los que agora son de la mi casa, que entonçes serán dela suya, como alos que agora son de la suya, segund que yo lo acostumbré de dar", Testamento de Enrique III (1406-12-24, Toledo) en García de Santa María, A.: Crónica de Juan II..., cap. VI, p. 41; “Al Rey Don Juan. Muy noble e virtuoso Señor. El Doctor Rui López, de vuestro Consejo, e vuestro Contador mayor (....) vos face saber que el Rey [Enrique III] vuestro padre, aunque indigno, me facia merced de un vestido de invierno, y otro de verano; e pues vos aveisle sucedido, mayormente en la largueza, ruegovos que me deis el vestido de invierno, que lo he bien menester", Carta de Ruy López, contador mayor y del Consejo, a Juan II de Castilla, en C. Rosell (ed.): Crónicas..., vol. II, doc. X, p. 255; "Noble Rey, yo adorando / vuestra alteza manifiesta, / aunque passada es la fiesta / non se pierda mi aguilando. / Señor, lo que vos demando / es alguna gentil ropa, / balandrán, galdrapa, opa, / con que me vaya presçiando. / ¡Non se pierda mi aguinando!", Este dezir fizo el dicho Alfonso Álvarez al señor Rey don Enrique pediéndole aguilando una fiesta de Navidad (ca. 1406), ID1201, en B. Dutton; J. González Cuenca (eds.): Cancionero de Juan Alfonso de Baena, Madrid, 1993, no 59, p. 83, vv. 1-9.

${ }^{104}$ Sobre el papel de los vestidos como objeto de regalo véanse los apuntes recogidos en PIPONNIER, F.; Mane, P.: Dress..., pp. 33-36, con un contexto general sobre el papel cortesano del regalo en nota 313.

${ }^{105}$ Martínez Martínez, M.: "La imagen del rey a través de la indumentaria", Bulletin Hispanique, 96: 2, (1994), pp. 277-287, p. 286; Martínez Martínez, M.: "Los gastos suntuarios de la monarquía castellana: aproximación a los aspectos técnicos y económicos a través del ejemplo de Juan I", en $I X$ Jornadas d'Estudis Historics Locals. La manufactura urbana i els menestrals (ss. XIII-XVI), Palma de Mallorca, 1991, p. 116.

${ }^{106}$ Alguno de estos sabemos que era específicamente "camocán colorado de lo de Granada", Relación..., (1398-07-29, Toro), fol. 513v [asiento tachado] o que habían sido traídos "desde Sevilla a esta dicha villa de Toro", Relación..., (1398-07-05, Toro), fol. 513r.

${ }^{107}$ Se trataría del alhame, una especie de camisa o túnica, en atención a lo señalado en PUIGVERT OcAl, A.: "El léxico de la indumentaria...", p. 189, referido en la Relación como "una alhame de seda, con sus orillas de seda colorada", en Relación..., (1398-01-01, Madrid), fol. 506r y de unos borceguíes, de origen morisco, Relación..., (1398-07-05, Toro), fol. 513r.

${ }^{108}$ Sobre este aspecto véase: Blanc, O.: "From Battlefield to Court: the invenction of fashion in the Fourteenth Century", en Encountering Medieval Textiles and Dress: Objects, Texts, Images, Nueva York, 2002, pp. 157-172. 
do exageradamente ciertas partes del cuerpo y borrando otras"109. En este sentido, si la silueta recortada tenía su origen último en aquel conjunto de prendas ajustadas al cuerpo derivadas de la indumentaria militar (como el laudel, el jaque o el jubón), las siluetas ampulosas (asociadas a la hopa complida o larga) suponían una continuidad con los antiguos trajes talares de los siglos XIII y XIV, cuyo interés residiría, como nos explica Juan de Sevilla, en su capacidad de expresar honestidad, cuando no a motivos prácticos de abrigo y protección ${ }^{110}$.

Las prendas eran, con frecuencia, realizadas por artífices que trabajaban al servicio de la corte real, como el sastre Pedro Sánchez ${ }^{111}$, y los bordadores Leonor López ${ }^{112}$, Juan o Juanín, de origen inglés ${ }^{113}$, y Pedro Fernández ${ }^{114}$, para los cuales fueron comprados, el 17 de diciembre de 1397, "bastidores para broslar algunas cosas que conplía" a servicio del rey ${ }^{115}$. Además, conocemos el nombre de, al menos, dos pellejeros vinculados a la corte: Juan Fernández, pellejero de la reina Catalina de Lancaster ${ }^{116}$, y Alfonso Fernández, pellejero "de la cámara", quien se encargó, en mayo de 1398, de hacer peñas a partir de veintiocho mazos de grises, en el que habría 1.400 pieles de este animal ${ }^{117}$. La inmensa mayoría de las prendas, como parecen indicar las frecuentes referencias al tajado o corte de las telas por parte de los sastres al servicio del rey, hubieron de ser confeccionadas en el seno de la corte, aunque no falta algún caso en el que tenemos conocimiento que de que pudieron tener su origen en una merced, intercambio o compra a algún noble ${ }^{118}$, o en actos de confiscación, como permite suponer la presencia de unos cascabeles y seguramente una hopa pertenecientes al caído en desgracia, en 1394, Fadrique Enríquez, duque de Benavente ${ }^{119}$, en línea con otras confiscaciones regias llevadas a cabo durante el reinado, como aquella de las "tierras e bienes que [Alfonso Enríquez, conde de Noreña] avía en el Regno", en $1394^{120}$, o de los "çient mill florines e mucha plata" que tenía en Burgos el cardenal Pedro Fernández de Frías, en $1405^{121}$.

\footnotetext{
109 Bernis Madrazo, C.: Indumentaria..., p. 29.

110 "las anchas son buenas para llevarlas encima de otras, por dos razones: la una, por ser honestas; la otra, por proteger del viento y del agua; además, en primavera protegen del Sol, pero no calientan, porque son bastante anchas", AvIÑón, J. de: Sevillana ..., cap. VII, p. 123.

${ }^{111}$ Relación..., fols. 500r-501v, 502v-503r, 504r-504v, 505v, 507r-507v, 509v-513v.

${ }_{112}$ Relación..., fols. 502v, 508r, 509r, 510r, 510v, 512v.

${ }^{113}$ Relación..., fols. 508v, 509r, 512v.

114 Relación..., (1397-12-17, Madrid), fol. 504v.

${ }^{115}$ Relación..., (1397-12-17, Madrid), fol. 504v, referido dicho bastidor nuevamente en Relación..., (1397-12-17, Madrid), fol. 504v; Relación..., (1398-07-08, Toro), fol. 513v.

116 Relación..., (1398-03-06, Toledo), fol. 509r.

117 Relación..., (1398-05-09, Tordesillas), fol. 511r.

${ }^{118}$ Relación..., (1398-03-07, Toledo), fol. 509r.

119 Referencia a estos cascabeles y hopa, esta última referida simplemente como "fue del Duque", en Relación..., (1397-09-13, Salamanca), fol. 500v; Relación..., (1397-09-18, Salamanca), fol. 500v. Sobre la caída del duque de Benavente véase SuÁRez Fernández, L.: "Nobleza y monarquía...", pp. 347-348.

${ }^{120}$ López de Ayala, P.: Crónica del rey don Enrique Tercero..., año 1394, cap. XXVIII, pp. 230-231.

121 Pérez de Guzmán, F.: Generaciones..., cap. 32, p. 163.
} 


\subsection{LOS ORNAMENTOS LITÚRGICOS Y EL ORATORIO DE LA CAPILLA REAL}

La Relación de efectos, cuyos asientos permiten reconstruir muy parcial y fragmentariamente el entorno material y ceremonial de la capilla real, nos informa acerca de la confección, comisionada en algún caso a Juan Vázquez, arcediano de Sevi$1 \mathrm{a}^{122}$, de: ornamentos litúrgicos para la capilla real (casullas, dalmáticas, frontales con "çielo e espaldas"), realizados en damasquín o camocán ${ }^{123}$ y forrados en lienzo y bocací, encontrándose específicamente, por un lado, las dalmáticas decoradas con imperial colorado y con "quatorze baras de çintas de seda de colores anchas, en que estavan figuras de Anus Dey e de escudos verdes" y, por otro, el frontal, con cielo e espaldas, con cenefas "adonde se pone la flocadura, una vara e media de çendal ancho colorado" 124 ; dos almadraquejas -es decir, una especie de cojines o colchones de pequeño tamaño ${ }^{125}$ - de fustán, y dos tapetes $-\mathrm{O}$ sea, una "alfombra pequeña y manual" 126 - para la asistencia del monarca a las misas ${ }^{127}$; dos almohadas de baldoque colorado brocadas con oro, con los caireles y borlas de oro y seda' ${ }^{128} ;$ y "tres paños de cortinas para quando oe misa el Rey" ${ }^{129}$, confeccionados en satín colorado y forrados de cendal verde, que conformarían el conocido como oratorio o cortinas, en cuyo interior el rey asistía a las ceremonias litúrgicas ${ }^{130}$, definiendo, en su conjunto, una imagen ceremonial en línea con la recomendación expuesta por Pero López de Ayala en su Rimado de palacio ${ }^{131}$.

${ }^{122}$ Debe tratarse del mismo que, en 1395, ejercía como capellán mayor del rey, quien se encargó de la gestión, con el obispo de Oviedo, para el traslado de algunas reliquias al monasterio de San Benito de Valladolid. Cf. Zaragoza Pascual, E.: Los generales de la Congregación de San Benito de Valladolid. I. Los priores (1390-1499), Silos, 1973, pp. 38-39.

${ }^{123}$ No parece claro si se trata de una u otra tela pues, en este punto, la Relación de efectos presenta alguna incongruencia, al referir indistintamente una u otra tela.

${ }^{124}$ Relación..., (1398-01-07, Madrid), fol. 507r; Relación..., (1398-01-14, Madrid), fol. 507v; Relación..., (1398-01-¿11?, Madrid), fol. 507v; Relación..., (1398-01-28, Madrid), fol. 508r.

${ }^{125}$ Cejador, J.: Vocabulario..., p. 27; Alonso, M.: Diccionario..., t. I, p. 247.

126 Diccionario de la lengua castellana (...). Compuesto por la Real Academia Española, Madrid, 1739, t. VI, p. 225.

127 Relación..., (1398-05-16, Tordesillas), fol. 511v.

128 Relación..., (1398-02-27, Toledo), fol. 509r; Relación..., (1398-05-30, Tordesillas), fol. 512r, algunas de las cuales deben ser las referidas en Relación..., (1398-01-12, Madrid), fol. 507v.

${ }^{129}$ Relación..., (1398-01-14, Madrid), fol. 507v.

${ }^{130}$ Sobre los usos e implicaciones de la cortina es de ineludible consulta el trabajo de FernándeZSantos Ortiz-Iribas, J.: "Ostensio regis: la Real Cortina como espacio y manifestación del poder soberano de los Austrias españoles", Potestas: Religión, Poder y Monarquía, 4 (2011), pp. 167-210, con apuntes específicos para la corte de Juan II en Cañas Gálvez, F. de P.: "La cámara de Juan II", p. 145.

131 "Para servir a Dios, aya toda vegada / su capilla muy noble, rricamente apostada; / de nobles ornamentos, fermosa, bien orrnada; / de buenos capellanes, muy bien aconpañada", LóPEZ DE AYALA, P.: Rimado de palacio, ed. de G. Orduna, Madrid, 1991, copla 626, p. 240. 


\subsection{LA ORFEBRERÍA CORTESANA}

La Relación de efectos ofrece algunas informaciones puntuales sobre orfebrería, relativas a: copas, generalmente realizadas en plata dorada, con su correspondiente sobrecopa o tapadera con decoración zoomorfa o vegetal ("fegura de ave"; "fegura de flor de lirio de planta blanca"; "figura de lilio blanca"; "figura de sierpe")"132; un firmal de oro, es decir, una joya en forma de broche, decorado con aljófar y piedras preciosas, con "una figura de cabeça de onbre con su barva luenga" ${ }^{133}$; sortijas en oro o plata dorada, generalmente decoradas con piedras preciosas (una esmeralda o un doblete, es decir, una piedra falsa) ${ }^{134}$; un collar de oro, decorado con aljófar, zafiros, balajes y "rrosillas de esmalte blanco" 135; diversas piezas de vajilla-que constituirá una de las principales fuentes de expresión de la magnificencia cortesana tardomedieval-, entre las que es posible citar: servillas o copas ${ }^{136}$ de plata blanca ${ }^{137}$; saleros de plata $^{138}$, que, al menos a fines del siglo XV, podían adoptar múltiples formas ${ }^{139}$; salseros de plata blanca ${ }^{140}$; jarras de plata dorada "de levar agua"141; gubiletes (gobilletes) o cubiletes de plata dorada, usados para beber ${ }^{142}$; servidores de plata, empleados para ayudar a cortar (tajar) ante el rey ${ }^{143}$; bacinas doradas ${ }^{144}$, utilizadas, como nos muestran algunos datos relativos al reinado de Juan II, como recipientes auxiliares en el ceremonial del banquete, bien para portar los paños e instrumentos empleados por el trinchante ${ }^{145}$, bien para desechar huesos y sobras ${ }^{146}$, bien para el ritual del lavamanos, en el caso de aquellas referidas como "de dar agua de manos" o "dar agua a manos" plateles dorados, es decir, platos para el consumo de carne o pescado ${ }^{148}$; escudillas

${ }^{132}$ Relación..., fols. 501r, 502v, 506v, 508r-508v.

133 Relación..., (1398-01-00, Madrid), fol. 508v.

134 Relación..., (1397-11-04, Madrigal), fol. 502r; Relación..., (1398-01-01, Madrid), fol. 506r; Relación..., (1398-05-29, Tordesillas), fol. 512r; Relación..., (1398-07-17, Toro), fol. 513v.

${ }^{135}$ Relación..., (1397-11-19, San Martín de Valdeiglesias), fol. 502v.

${ }^{136}$ Cejador, J.: Vocabulario medieval castellano, Madrid, 1990, p. 360.

${ }^{137}$ Relación..., (1397-12-¿29?, Madrid), fol. 506r, citadas igualmente en Relación..., (1398-01-01, Madrid), fol. 506v.

${ }^{138}$ Relación..., (1397-12-¿29?, Madrid), fol. 506r.

139 González Marrero, M. del C., La Casa..., pp. 175-176.

${ }^{140}$ Relación..., (1397-10-11, Toro), fol. 501r.

${ }^{141}$ Relación..., (1397-12-¿29?, Madrid), fol. 506r, una de ellas citada igualmente en Relación..., (1398-01-01, Madrid), fol. 506v.

${ }^{142}$ Relación..., (1397-12-¿29?, Madrid), fol. 506r, citados nuevamente en Relación..., (1398-01-01, Madrid), fol. 506v. Sobre su uso como recipiente para beber, véase DíAz de Games, G.: El Victorial, cap. 50, p. 308, con un breve apunte tipológico en González Marrero, M. del C.: La Casa..., p. 182.

${ }_{143}$ Relación..., (1397-12-¿29?, Madrid), fol. 506r, referido igualmente en Relación..., (1398-01-05, Madrid), fol. 507r.

${ }^{144}$ Relación..., (1398-01-01, Madrid), fol. 506r.

${ }^{145}$ Villena, E. de: Arte cisoria, ed. de R.V. Brown, Barcelona, 1984, cap. 5, pp. 77-78, 80-81.

146 Villena, E. de: Arte..., cap. 5, pp. 79-80.

147 González Marrero, M. del C.: La Casa..., p. 175.

148 Relación..., (1398-01-01, Madrid), fol. 506r, con apuntes sobre estos en GonZÁlez Marrero, M. del C.: La Casa..., pp. 185-186 
doradas, empleadas para aquellos alimentos de consistencia untosa o líquida ${ }^{149}$; cazos o tazas confeccionados en plata dorada, con decoración "en medio [de] çinco leones" ${ }^{150}$; un anillo de oro para sellar, sobre el que hablaremos monográficamente más adelante ${ }^{151}$; o decoraciones de flocaduras, en hilo de oro, para los frenos de las mulas del rey ${ }^{152}$. Sabemos del origen de algunas de las piezas de orfebrería citadas en la Relación de efectos, procedentes de la propia recaudación de los tesoreros de las casas de la moneda, recaudadores o contadores; o -si no es que se trató, en algún caso, de pagos en metal atesorado- de presentes dirigidos al monarca, como la copa, con su correspondiente sobrecopa, decorada con la figura de una sierpe, entregada al rey por Martín Fernández Cerón, alcalde mayor de Sevilla ${ }^{153}$, o el firmal regalado por Martín I de Aragón a Enrique III, recibidos ambos en la cámara en enero de $1398^{154}$.

Conocemos, a través de la Relación de efectos, la presencia de, al menos, tres orfebres trabajando al servicio de Enrique III: Íñigo Pérez de Sevilla, encargado de la confección de una imagen en plata de santa María con el Niño, en compañía, a sus pies, de la figura de Enrique III con armadura, espada, escudo y lanza, "con su pendón de satín colorado e broslado a las armas del dicho señor Rey", destinada a ser entregada como donación al monasterio de Santa María de Guadalupe ${ }^{155}$; maestre Juan, encargado de hacer en metal "unas rrosillas con unas letras para en hun laudel para Ruy Lópes" "156; y los moriscos Alonso Fernández y Antón Fernández, encargados de realizar seis argollas de plata para la decoración de una daga ${ }^{157}$, que habría de ser exhibida por la realeza en los cinturones -más como un recurso ceremonial, que con un fin práctico-o destinada, como obsequio, a algún personaje relevante ${ }^{158}$.

Las joyas se convertirán, así, en un elemento sobre el que se fundamentarían las relaciones políticas entre cortes ${ }^{159}$, como muestra la propia Relación de efectos, con

${ }^{149}$ Relación..., (1398-01-01, Madrid), fol. 506r, con referencia a sus usos en MARTín CEA, J.C.: "Entre platos, copas y manteles. Usos y costumbres sociales en torno a las comida en la Castilla bajomedieval", en Convivir en la Edad Media, Burgos, 2010, pp. 253-282, pp. 267-268; GonZÁLEZ MARrero, M. del C.: La Casa..., pp. 165, 185-186

${ }^{150}$ Relación..., (1397-12-27, Madrid), fol. 505v [asiento tachado], citadas igualmente en Relación..., (1398-01-01, Madrid), fol. 506v.

${ }^{151}$ Véase el apartado 5.4. Un anillo sigilar de Enrique III: sobre una práctica en la cancillería y la cimera del grifo de los reyes de Castilla.

${ }^{152}$ Relación..., (1398-05-28, Tordesillas), fol. 512r, en consonancia con la propia recomendación de las Partidas: "Et otrosi que trayesen los frenos et las siellas en que cavalgan de oro, et de plata et con piedras preciosas", Alfonso X, Las Siete Partidas...., t. II, Partida II, Título V, Ley V, p. 29.

153 Relación..., (1398-01-01, Madrid), fol. 506v.

${ }^{154}$ Relación..., (1398-01-00, Madrid), fol. 508v.

${ }^{155}$ Relación..., (1398-03-17, Toledo), fol. 509v; Relación..., (1398-04-09, monasterio de Sta. Ma de Pelayos), fol. 510v.

${ }^{156}$ Relación..., (1397-09-03, Salamanca), fol. 500r.

${ }^{157}$ Relación..., (1398-08-¿18?, Tordesillas), fol. 513v.

158 Cf. Mugueta Moreno, Í.; Osés Urricelqui, M.: "Gastos suntuarios...”, pp. 110-111. Informaciones adicionales sobre estas dagas en la corte de Enrique III en Relación..., (1397-11-29, Madrid), fol. 502v; Relación..., (1397-12-05, Madrid), fol. 503r; Relación..., (1398-08-¿18?, Tordesillas), fol. 513v.

159 "E dióles el Rey [Enrique III] de sus joyas, e partieron dende [los embajadores del rey de Francia] muy pagados e contentos dél", LóPEz DE AyAla, P.: Crónica del Rey don Enrique Tercero, año 1391, cap. $\mathrm{XV}$, p. 175; "e dava armas, e cavallos, e ricas ropas, e guarniçiones [a] aquellos que estas cosas avían 
ocasión de la recepción que Pedro Fernández haría para la cámara, en concepto de regalo, de una "espada de armas, que non tenía plata", ofrecida por un mensajero del duque de Bretaña ${ }^{160}$, o del firmal, ya citado, enviado por Martín I de Aragón a Enrique III de Castilla.

\subsection{OTROS OBJETOS DE USO COTIDIANO}

La Relación de efectos ofrece informaciones de interés para el conocimiento de la cultura material de la corte castellana de fines del trescientos, a través de la referencia a un conjunto de objetos de uso cotidiano, como: collares para alanos, decorados con las armas reales ${ }^{161}$; candeleros "de fierro, para en que estén fachas en las cámaras" colchas de paramentos y paños de cama ${ }^{163}$; pañicos, referidos de una manera genérica y sin función específica, confeccionados en lienzo (delgado, de sobrepelliz, de Remes) $)^{164}$; paños de narices, confeccionados en lienzo (delgado, de Remes) ${ }^{165}$; almohadas -rellenas de lana o pluma- con formas diversas (almohada, propiamente dicha, y la empleada específicamente para reclinar la cabeza, denominada cabezal o travesero), confeccionadas en lienzo, en baldoque, en seda o en satín, ya lisas, ya bordadas en seda, ya jaqueladas, para los ámbitos más íntimos del espacio doméstico, pues algunas de ellas iban a juego con los paños de camas, o para los estrados del monarca ${ }^{166}$; "sávanas pequeñas para escalentar los pies del dicho señor Rey", realizadas en lienzo de Flandes o lienzo blanco delgado ${ }^{167}$; almadraquejas, confeccionadas en

de fazer, espeçialmente quando venían a su corte enbajadores e estranjeros de otros reynos", DíAz DE GAMES, G.: El Victorial, cap. 30, p. 255.

${ }^{160}$ Relación..., (1398-01-24, Madrid), fol. 508r.

${ }^{161}$ Relación..., (1398-01-01, Madrid), fol. 506r, que probablemente sean de los regalados "de tapete azul, con sus fierros dorrados brosllados de oro e de seda. Et tiene cada vno d'ellos çinco escudos a las armas del rrey, los tres, en $e$ l collar, e los dos, en los fierros. Et más quatro traýllas de lana", junto con algunos alanos, al rey de Aragón el 28 de marzo de 1398 en Relación..., (1398-03-28, Santa Olalla), fol. 510r, similares a los que trece años después remitiría el infante Fernando de Antequera al rey de Francia, en 1411: "Y el Infante le envió (...) diez alanos e dos hembras con collares de oro é traillas de seda muy bien obradas", Pérez de GuzMÁn, F.: Crónica del serenísimo príncipe don Juan, segundo rey deste nombre en Castilla y en León, en C. Rosell (ed.): Crónicas..., vol. II, año 1411, cap. XX, p. 339-340. En relación con estos atavíos para perros de caza en la Castilla del cuatrocientos se pueden examinar las figuraciones en Alfonso XI, Libro de Montería, Real Biblioteca, II/2105, fols. 15v, 83v, 91r, 91v, con muestra de un collar con decoración heráldica en Maestro de Miraflores, Prisión de San Juan Bautista (ca. 1490-1500), Museo Nacional del Prado, $\mathrm{n}^{\circ}$ de cat. P00709, procedente de la Cartuja de Miraflores (Burgos).

${ }^{162}$ Relación..., (1397-12-22, Madrid), fol. 504v.

163 Relación..., (1398-01-01, Madrid), fol. 506r; Relación..., (1398-01-07, Madrid), fol. 507r; Relación..., (1398-02-12, Illescas), fol. 508v; Relación..., (1398-05-14, Tordesillas), fol. 511r; Relación..., (1398-05-24, Tordesillas), fol. 512r, con referencias sobre las mismas en época de Isabel I de Castilla en González Marrero, M. del C.: La Casa..., pp. 200-203 y análisis simbólico del lecho o cama de estado como insignia de la realeza en Fernández De Córdova Miralles, Á.: "Los símbolos del poder real", en Los Reyes Católicos y Granada, Granada, 2005, pp. 37-58, p. 54.

${ }^{164}$ Relación..., fols. 500v, 502v, 508r, 510r, 510v, 513v.

${ }^{165}$ Relación..., (1397-11-29, Madrid), fol. 502v; Relación..., (1398-02-23, Toledo), fol. 509r; Relación..., (1398-02-28, Toledo), fol. 509r; Relación..., (1398-07-12, Toro), fol. 513v.

166 Relación..., fols. 506r-506v, 507v, 508v, 510v, 512v, 513r [asiento tachado].

167 Relación..., (1398-04-28, Ávila), fol. 511r; Relación..., (1398-06-10, Tordesillas), fol. 512v. 
fustán, y guadamecíes de cuero colorado ${ }^{168}$ para los estrados del monarca ${ }^{169}$, cuyo uso ceremonial parece tener una inspiración hispanomusulmana ${ }^{170}$; una tienda y un tendejón de lienzo ${ }^{171}$; una vaina, realizada en satín colorado, para una "espada de armas, que el rrey mando guarnesçer" ${ }^{172}$; o dos hachas ${ }^{173}$.

\section{CINCO NOTAS EN TORNO A LA RELACIÓN DE EFECTOS SOBRE LA VIDA COTIDIANA Y CULTURAL EN LA CORTE DE ENRIQUE III}

\subsection{NAVIDAD Y SEMANA SANTA EN LA CORTE DEL REY}

La celebración de la liturgia religiosa en la corte respondía a la necesidad de honrar las fiestas de la Iglesia, a la vez que constituía, desde el punto de vista político, un elemento destacado en la construcción de la imagen de la realeza cristiana ${ }^{174}$. Cronológicamente, siguiendo el curso del año litúrgico, la Relación de efectos ofrece abundantes referencias sobre algunas prácticas características de las fiestas de Navidad, entre las que cabe destacar: la participación del monarca o de sus colaboradores en juegos durante la Nochebuena y los días que seguían a esta, en relación con los cuales se confeccionaron, a cargo del tornero maestre Abrahán, juegos ${ }^{175}$ y se hubieron de entregar diversos dineros para jugar ${ }^{176}$, siguiendo prácticas documentadas para los rei-

${ }^{168}$ El guadamecí es una piel de carnero curtida y posteriormente dorada, policromada y con relieves, empleada en la tapicería de muros, cortinas, frontales, almohadas o alfombras. Aguiló, M.P.: "Cordobanes y guadamecíes", en Historia de las artes aplicadas e industriales en España, Madrid, 1994, pp. 325-336, pp. 331-334; Ferrandis Torres, J.: Cordobanes y guadamecies, Madrid, 1955, p. 15.

${ }^{169}$ Relación..., (1398-01-18, Madrid), fol. 507v; Relación..., (1398-05-28, Tordesillas), fol. 512r; Relación..., (1398-06-03, Tordesillas), fol. 512v; Relación..., (1398-06-21, Toro), fol. 513r [asiento tachado]; Relación..., (1398-06-26, Toro), fol. 513r [asiento tachado], con notas para la corte de Isabel I en González Marrero, M. del C.: La Casa..., pp. 143-144, 149-150; Fernández de Córdova Miralles, Á.: "Los símbolos...", p. 46, los cuales, junto con las alfombras, constituirían productos suntuarios característicos del ámbito castellano: "y embióle muchos cueros de guadamecir e muchas alhombras, porque es cosa que en Francia no se han”, Pérez de GuzMán, F.: Crónica del serenísimo príncipe don Juan segundo..., año 1411, cap. XX, p. 339.

${ }^{170}$ Cf. Silva SAnta Cruz, N.: "Maurofilia y mudejarismo en época de Isabel la Católica", en Isabel la Católica: la magnificencia de un reinado, Madrid, 2004, pp. 141-154, p. 142; Pérez Higuera, T.: Objetos e imágenes..., p. 51, con referencias exhaustivas a dicho uso ceremonial en el ámbito andalusí en Pérez Higuera, T.: Objetos e imágenes..., pp. 36-51. Existe un testimonio iconográfico de interés sobre el posible aspecto del estrado regio en el citado testimonio ACS, sección IX, carpeta $116, \mathrm{n}^{\circ} 42$ y en Alfonso X, Siete Partidas, BNE, Manuscritos, Mss. 12794, fol. 2r., donde el rey aparece sobre un estrado o plataforma, sobre la que se dispone una almohada, con función de trono.

${ }^{171}$ Relación..., (1398-07-05, Toro), fol. 513r.

172 Relación..., (1398-08-¿18?, Tordesillas), fol. 513v.

${ }^{173}$ Relación..., (1398-01-18, Madrid), fol. 508r.

174 Dicha imagen sería sintetizada por Gutierre Díaz de Games en el pasaje: "El rey don Enrique hera magnánimo e muy católico, e honrava mucho las yglesias e las fiestas de Dios, e de Santa María, e de los Apóstoles, e de los otros santos”, Díaz de Games, G.: El Victorial, cap. 30, p. 255.

${ }^{175}$ Relación..., (1397-12-26, Madrid), fol. 505v [asiento tachado].

176 "En esta dicha villa este dicho día, dy yo el dicho Pero Ferrándes, por mandado del Rey, a Ruy Lópes de Dávalos, su camarero, para que él jugase, sesenta florines, que son IUCCCXX”, Relación..., (1397-12-24, Madrid), fol. 505r; "Este dicho día, dy más yo el dicho Pero Fferrándes, por mandado del 
nados de Juan I o Enrique IV de Castilla ${ }^{177}$; la tradición del intercambio de presentes, en concepto de aguinaldo (aguilando), con personas del entorno más inmediato del monarca ${ }^{178}$; la elaboración de dulces, como unos confites elaborados para Enrique III con seis libras de pistachos (alfóstigos), cuyo precio hubo de ascender a $90 \mathrm{mrs} .{ }^{179}$; la entrega de una limosna a la capilla real el día de Navidad ${ }^{180}$; o el desarrollo de ceremonias de carácter festivo, en relación con las cuales hubo de ser probablemente realizado un banco, cuyo coste ascendió a 10 mrs., pagados a "dos carpenteros"

Avanzando en el año litúrgico, la Relación de efectos ofrece referencias sobre la confección, por parte del sastre Pedro Sánchez, de un conjunto de prendas de luto (un mantón, una hopa, unas calzas y un capirote), realizadas "en paño de bruneta de breos", para la participación del monarca en las ceremonias de Semana Santa, específicamente, en las de Viernes Santo ${ }^{182}$.

\subsection{LA PRÁCTICA DE LA MEDICINA: UNA RECETA MÉDICA PARA EL REY}

El perfil biográfico de Enrique III hubo de estar marcado por su precaria salud, reflejada en el apelativo de el Doliente o el Enfermo, de la que darían buena cuenta las diversas semblanzas realizadas por los cronistas y poetas cortesanos del cua-

Rey, a Pero Carrillo de Toledo, su criado, para que él jugase, treynta florines, que son DCLX”, Relación..., (1397-12-24, Madrid), fol. 505r.

177 Sobre esta costumbre en la corte castellana véanse la referencias en CAÑAS GÁlVEZ, F. de P.: "La Casa de Juan I...”, p. 161; LADERo Quesada, M.Á.: “1462: un año...”, p. 247.

178 Bajo el concepto de aguinaldo son referidas diversas dávidas los días 1 y 3 de enero de 1398 en: Relación..., fols. 506r-507r. De difícil interpretación es la recepción de diversas piezas de plata, collares, paños, etc. por Pedro Fernández, de manos de María, mujer de Juan Hurtado de Mendoza, de Teresa Cisneros y de Elvira, mujer de Ruy López Dávalos, en Relación..., (1398-01-01, Madrid), fol. 506r. Sobre esta costumbre del aguinaldo véase: LADERo QuESADA, M.Á.: Las fiestas en la cultura medieval, Barcelona, 2004, p. 37; LADERo Quesada, M.Á.: "1462: un año...”, p. 247; RuBio García, L.: “Aguinaldo / Aguilando", Estudios Románicos, 8-9 (1993-1995), pp. 143-149; SÁnchez Domingo, R.: "Origen histórico-jurídico del aguinaldo: del strenna romano al salario en especie", en La Natividad: arte, religiosidad y tradiciones populares, San Lorenzo de El Escorial, 2009, pp. 715-730.

179 "Este dicho día, dy, por seis libras de alfóstigos, para fazer confites al Rey, noventa maravedies", Relación..., (1397-12-27, Madrid), fol. 505v [asiento tachado]. La voz confite, como señala José Pérez Vidal "no tenía en el siglo XIV el sentido restringido que ha tenido después", PÉreZ VIDAL, J.: Medicina y dulcería en el Libro de Buen Amor, Madrid, 1981, p. 244, pudiendo ser definida, siguiendo a Covarrubias, como "la confección de la almendra, avellana, piñón, o otra qualquier fruta, o semilla incorporada, o cubierta con el açúcar", Covarrubias Orozco, S. de: Tesoro..., fol. 232v. Así, los confites tenían como ingredientes principales el azúcar-siendo especialmente apreciado el azúcar blanco refinado-, frutos secos, flor de harina, etc., como muestran algunas de las recetas castellanas compiladas en el cuatrocentista Vergel de señores, en el cual se muestran a hacer con mucha excelencia todas las conservas, electuarios, confituras, turrones y otras cosas de azúcar y miel, BNE, Manuscritos, Mss. 8565, fols. 52v-57v.

${ }^{180}$ Relación..., (1397-12-25, Madrid), fol. 505v [asiento tachado]. Sobre esta costumbre en la corte castellana: Ladero Quesada, M.Á.: “1462: un año...”, p. 247; Villalobos y Martínez-Pontrémuli, M.L. de: "Las gestiones hacendísticas...", p. 186.

${ }^{181}$ Relación..., (1397-12-27, Madrid), fol. 505v [asiento tachado].

182 Relación..., (1398-04-04, monasterio de Sta. Ma de Pelayos), fol. 510v; Relación..., (1398-04-04, monasterio de Sta. $\mathrm{M}^{\mathrm{a}}$ de Pelayos), fol. 510v. 
trocientos ${ }^{183}$. Dicha enfermedad, identificada hipotéticamente con "un padecimiento tipo tuberculosis" ${ }^{184}$, que acabaría por desembocar en la muerte del monarca el 25 de diciembre de 1406, habría comenzado a manifestarse, de ser cierto lo que nos relata Fernán Pérez de Guzmán ${ }^{185}$, a partir de los diecisiete o dieciocho años, es decir, durante el período de tiempo que cubre la Relación de efectos. Gracias a esta sabemos que a inicios de 1398 Enrique III tenía cerca de su persona a los médicos (físicos) $)^{186}$ maestre Andrea ${ }^{187}$, Mayr Alguadex ${ }^{188}$, maestre Juan ${ }^{189}$ y Mosseh Aben-Zarzal ${ }^{190}$, quienes, en aprecio por los servicios prestados al monarca, hubieron de recibir diversas piezas de chamelote el jueves 3 de enero de 1398, con ocasión de las fiestas navideñas. Además de las funciones genéricas asociadas a estos oficiales en las cortes bajomedievales, entre las cuales se encontraba la vigilancia de la comida regia ${ }^{191}$ y el análisis matinal de la orina o uroscopia $^{192}$, por algunas informaciones puntuales de inicios del siglo $\mathrm{XV}$ sabemos que sobre los físicos reales recaía no solo la función diagnóstica, sino también el examen -al menos, en aquellas ocasiones en las que el paciente mostrara

${ }^{183}$ Sobre este hecho, véase: Mitre Fernández, E.: Una muerte para un rey. Enrique III de Castilla, Valladolid, 2001, pp. 47-49; Mitre Fernández, E.: "La formación de la imagen del rey en la historiografía castellana del siglo XV: Enrique III de Trastámara", en XVII Congreso Internacional de Ciencias Históricas. II. Sección Cronológica. Metodología: la biografia histórica, Madrid, 1992, pp. 1131-1137, p. 1137; Mitre Fernández, E.: "Lo real, lo mítico y lo edificante en la precaria salud de un monarca medieval: Enrique III de Castilla como paradigma (1390-1406)", Hispania Sacra, 113 (2004), pp. 7-28, especialmente pp. 17-18.

${ }^{184}$ Mitre Fernández, E.: Una muerte..., p. 49; Mitre Fernández, E.: “Lo real...”, pp. 18-23.

185 Pérez de Guzmán, F.: Generaciones y semblanzas, ed. de José Antonio Barrio, Madrid, 1998, cap. I, pp. 69-70.

${ }^{186}$ Sobre estos médicos en el tránsito del siglo XIV al XV en la corte de Castilla véase Amasuno SÁrraga, M.V.: Alfonso Chirino, un médico de monarcas castellanos, Valladolid, 1993, pp. 59-81; CAÑAS GÁlvez, F. de P.: "La Casa de Juan I...", p. 156-157, con un marco general al respecto en Salazar Y ACHA, J. de: La Casa ..., pp. 295-301 y CAÑAS GÁlvez, F. de P.: "La cámara de Juan II", pp. 127-129.

187 Relación..., (1398-01-03, Madrid), fol. 507r. Se trataría del mismo maestre Andrea, italiano físico del rey y "primero médico de la ciudad" de Sevilla, de probable origen judío, en opinión de Marcelino V. Amasuno, que hubo de asistir a la muerte del obispo de Sigüenza, Juan Serrano, en Sevilla, en 1402. Amasuno Sárraga, M.V.: Alfonso Chirino..., p. 67; Nieto Soria, J.M.: Un crimen en la corte. Caída y ascenso de Gutierre Álvarez de Toledo, Señor de Alba (1376-1446), Madrid, 2006, pp. 120-123, 140.

${ }^{188}$ Relación...., (1398-01-03, Madrid), fol. 507r. Sobre este, véanse los apuntes recogidos en GARCíA BALlester, L.: Sanadores y enfermos en la España medieval, Barcelona, 2001, pp. 124, 187, 214-215, $262,269,317,326,342,424-435,454,457,462,468-469,473-484,555,593$, con referencia específica a su proceso en Amasuno Sárraga, M.V.: Alfonso Chirino..., pp. 78-80.

189 Relación..., (1398-01-03, Madrid), fol. 507r. Este podría identificarse, con muchas prevenciones, según Marcelino V. Amasuno, con maestre Juan de Toledo, futuro físico de Juan II, autor de la Relación con motivo de la enfermedad que, en 1415, aquejó a Fernando I de Aragón, en su posición de médico de cámara del rey aragonés, tratándose con seguridad, en cualquier caso, del mismo físico real que hubo de atender en Toro, en 1405, a la reina Catalina, durante el nacimiento del príncipe Juan. Cf. AmAsuno SÁrraga, M.V.: Alfonso Chirino..., pp. 64-66.

190 Relación..., (1398-01-03, Madrid), fol. 507r. Se trata del mismo referido en el conocido como Sumario del despensero, cuyo padre, Abrahen Aben-Zarzal, había ejercido el oficio de físico en la corte de Pedro I. Rodríguez de Cuenca, J.: Sumario..., cap. XL, pp. 61-62, 74-75.

191 "Físicos e capellanes a la su mesa son; / allí fazen sus sermones e disputan su quistión; / cada uno lo que sabe, pónelo por inquisiçión; / maguer fazen argumentos, ál tienen en coraçón”, LóPEZ DE AYALA, P.: Rimado de palacio, copla 482, p. 214.

${ }^{192}$ Ladero Quesada, M.Á.: “La Casa Real...”, p. 338. 
signos de debilidad- del espacio donde se asentaría la corte ${ }^{193}$, quizás manifestación de aquellas teorías médicas que, dentro de la tradición conocida como ambientalista, metereologista o aerista, inaugurada por el tratado hipocrático Sobre aires, aguas y lugares ${ }^{194}$, ligaban la condición del aire al estado de la salud humana, de la que son buenas muestras, en el ámbito castellano, el galénico Libro de medicina castellana regia (Kitab al-tibb al-qastali al-maluki) o Libro sobre las práctica médica adaptada a los lugares de Castilla (ca. 1312), redactado por un judío, probablemente de Toledo, médico de Fernando IV ${ }^{195}$, y la Sevillana medicina (ca. 1384), de Juan de Aviñón ${ }^{196}$.

Junto a estos físicos, se encontraban los boticarios, encargados de la elaboración de los remedios médicos, cuyas funciones, según apunta Miguel Ángel Ladero Quesada, "no se limitaban a la farmacia, como su nombre podría sugerir, sino que era a la vez el confitero y el droguero del rey" ${ }^{197}$; aspecto que acercaría esta figura del boticario, como señala Fernando Serrano Larráyoz para la corte navarra, a un conjunto de funciones "desempeñadas por los actualmente farmacéuticos, los confiteros y los tenderos" ${ }^{198}$. En los primeros días de abril, los boticarios reales habrían recibido el encargo de parte de los físicos de Enrique III para que confeccionaran un electuario ${ }^{199}$ para el rey, donde se hubo de diluir, una vez reducido a polvo, un balaje, o sea, un rubí de color morado, y un fragmento de ámbar gris, entregados por el camarero Pedro Fernández a los boticarios del rey el 11 de abril de $1398^{200}$.

Dicha fórmula magistral se encontraba en sintonía con otros electuarios confeccionados en la Castilla bajomedieval, que tenían, entre sus principios activos, sustancias de origen mineral o animal, como piedras preciosas, perlas, coral o marfil, al modo de

193 "Envióla [el Infante Fernando de Antequera] a ver a sus físicos, e a otros de su casa con ellos, e los que allí fueron pagáronse mucho de la posada e del asentamiento, del agua e de las huertas que ay tenían; e fiziéronle dello relaçión. E tanto ge la alabaron, que le plugo de yr allá", GARCíA DE SANTA MARÍA, A.: Crónica de Juan II..., cap. 39, p. 117.

194 CAsco Solís, J.: "Las topografías médicas: revisión y cronología", Asclepio: Revista de Historia de la Medicina y de la Ciencia, 53:1 (2001), pp. 213-244, pp. 215-216; CARMONA, J.I: Enfermedad y sociedad en los primeros tiempos modernos, Sevilla, Universidad de Sevilla, 2005, pp. 14-15.

${ }^{195}$ García Ballester, L.: La búsqueda..., pp. 455-472; Vázquez de Benito, M. de la C.: "Los médicos judíos castellanos del siglo XIV y el galenismo árabe: el Kitab al-tibb al-Qastaki al-Maluki (Libro de medicina castellana regia) (c. 1312)", Asclepio, 42 (1990), pp. 119-147.

196 AviÑón, J. de: Sevillana ..., caps. I-IV, VI-VII, LXV, con notas sobre la cronología de la obra en MondéJAR, J.: "Introducción”, en J. de Aviñón, Sevillana ..., pp. 7-58, pp. 26-29.

${ }^{197}$ LAdero Quesada, M.Á.: “La Casa Real...”, p. 338, con algún apunte adicional sobre la figura del boticario en la corte de Castilla en Salazar y Acha, J. de: La Casa..., p. 301; GonzÁlez Marrero, M. del C.: La Casa..., p. 105; GonzÁlez, C.A.; VAlverde López, J.L.: "Un boticario real de tradición medieval", Cuadernos de Estudios Medievales, 4-5 (1976-1977), pp. 237-253.

198 Serrano Larráyoz, F.: Medicina y enfermedad en la Corte de Carlos III El Noble de Navarra (1387-1425), Pamplona, 2004, p. 88, con algunas precisiones conceptuales adicionales al respecto en Serrano Larráyoz, F.: "Por apoticarias, medezinas et espeçierias tomadas. Aproximación al oficio de boticario en el reino de Navarra (siglos XIV-XV)", Anuario de Estudios Medievales, 42:2 (2012), pp. 837-865, pp. 844-847, 854.

199 Se trata de un compuesto dulce de consistencia líquida, pastosa o sólida, con base de miel, jarabe o azúcar, en la que se diluían "compuestos de polvos muy finos". Amasuno SÁrraga, M.V.: Medicina castellano-leonesa bajomedieval, Valladolid, 1991, p. 64; PÉrez VIdAL, J.: Medicina y dulcería..., pp. 143-157.

${ }^{200}$ Relación..., (1398-04-11, monasterio de Sta. $\mathrm{M}^{\mathrm{a}}$ de Pelayos), fol. 510v. 
los electuarios conocidos genéricamente bajo la denominación de diarrodon, diasen, o diamargariton ${ }^{201}$ o del prescrito para el mal de hígado, para vigorizar el corazón y para adobar el estómago por el doctor Gómez de Salamanca, a mediados del siglo $\mathrm{XV}^{202}$. Atendiendo a la compleja composición de estos electuarios y a la propia expresión empleada en la Relación de efectos ${ }^{203}$, no parece que esta receta médica estuviera confeccionada exclusivamente por los referidos polvos de balaje y perlas, sino que probablemente ambos compuestos se sumarían a otras sustancias, aportadas probablemente por los propios boticarios y pagadas al margen del camarero Pedro Fernández, en línea con lo indicado por las cuentas del boticario real Fernando López de Aguilar para el 1462, cuyos gastos eran costeados a cargo de los contadores mayores ${ }^{204}$.

Desconocemos la dolencia que pudo afectar a la salud del rey durante la primavera de 1398, aunque no sería extraño que este remedio médico tuviera que ver con la referida enfermedad que hubo de acompañar a Enrique III durante los últimos años de su vida. Tal aspecto podría venir sugerido atendiendo a la similitud de este remedio con otro prescrito al monarca para tratar su dolencia: aquel electuario que tenía como principio activo esmeraldas, referido por el médico real Alfonso Chirino como un "rico letuario con esmeraldas molidas, que costó cada peso dél veynte pesos de oro e fue fecho para el noble rey Don Enrique, de buena memoria" ${ }^{205}$, en línea con otros remedios que, en esta misma dirección, le fueron prescitos por los físicos reales a Enrique III en los últimos años de su vida y que, lejos de mejorar la situación del rey, en opinión de Chirino, la habrían empeorado ${ }^{206}$.

Quizá el estudio comparativo entre las recetas preparadas para Enrique III, conocidas gracias a Alfonso Chirino y a la Relación de efectos, con el recetario aljamiado hebraico-castellano, escrito hacia 1412 por un discípulo de Mayr Alguadex, compilando algunas de las recetas de su maestro ${ }^{207}$, actualmente inédito, podría ofrecer

${ }^{201}$ SÁnchez GonzÁlez de Herrero, M. de las N.: "Nombres de composiciones farmacológicas formados con la partícula griega dia contenidos en obras médicas medievales castellanas", Cahiers de Linguistique Hispanique Médiévale, 16 (1991), pp. 147-182, pp. 159-160, 171-172; Pérez VIDAL, J.: Medicina y dulcería..., pp. 217-218.

${ }^{202}$ Conpendio que fizo para el maestre de Santiago don Álvaro de Luna, Biblioteca Histórica de la Universidad de Salamanca, Mss. 2262, fols. 193r-216v, fols. 195r-195v en Amasuno SÁrraga, M.V.: El "Compendio de medicina" del doctor Gómez de Salamanca, Salamanca, 1971, p. 22; Reçeptas que fizo el doctor Gómez para el muy alto e muy esclareçido Rey Don Enrrique el Quarto, Nuestro Señor, RAH, Colección San Román, Ms. 46, fols. 123r-130r, fol. 123r.

203 "para echar en hun letuario que mandaron fazer los físicos para el Rey", Relación..., (1398-0411, monasterio de Sta. Ma de Pelayos), fol. 510v.

${ }^{204}$ GonzÁlez, C.A.; VAlverde López, J.L.: "Un boticario real...”, p. 251; García Ballester, L.: La búsqueda..., p. 588.

${ }^{205}$ ChIrIno, A.: Menor daño de la medicina. Espejo de Medicina, ed. de Á. González Palencia y L. Contreras Poza, Madrid, 1945, p. 96, con referencia igualmente en Amasuno SÁrraga, M.V.: Alfonso Chirino..., p. 67.

${ }^{206}$ Diversos testimonios al respecto, extractados de la obra de Alonso Chirino, han sido recopilados en Amasuno Sárraga, M.V.: Alfonso Chirino..., pp. 67, 70-71, 73, 78.

${ }^{207}$ Parma, Biblioteca Palatina, Ms. Hebreo 2474, IV, fols. 145r-155v, con un análisis del mismo en García Ballester, L.: La búsqueda..., pp. 473-484. 
nuevas perspectivas para el conocimiento de la enfermedad que aquejó al rey durante los últimos años de su vida.

\subsection{EL LIBRO DEL REGIMIENTO DE LOS PRÍNCIPES Y ALGUNAS NOTAS SOBRE LA EDUCACIÓN CORTESANA A FINES DEL TRESCIENTOS}

El 16 de mayo de 1398 Pedro Fernández entregaba al camarero Ruy López Dávalos el libro del Regimiento de los prínçipes, confeccionado en papel y encuadernado con cubiertas de cuero verde ${ }^{208}$. Se trataría probablemente de un ejemplar en castellano, en atención tanto a su título, como a la existencia a la altura de 1398 de dos traducciones castellanas - una segura y otra hipotética- de las obras que se podrían corresponder con este título en romance: la segura de De regimine principum, de Egidio Romano, vertida al castellano por Juan García de Castrojeriz a mediados del siglo XIV ${ }^{209}$, y la hipotética de De regno ad regem Cypri, de Tomás de Aquino, para la que se ha supuesto una posible traducción castellana en torno a los años del reinado de Enrique III, atendiendo a la datación que se ha ofrecido de dos ejemplares, actualmente conservados en la Biblioteca de El Real Monasterio de San Lorenzo de El Escorial ${ }^{210}$. La documentación de este ejemplar del Regimiento de los príncipes -ya sea la obra de Tomás de Aquino o más probablemente, debido a su amplia presencia, la de Egidio

208 "En esta dicha villa este dicho día, yo Pero Ferrándes, por mandado del Rey, a Rruy Lópes de Dávalos, su camarero, el libro del regimento de los prínçipes, escripto en papel, con sus coberturas de cuero verde", Relación..., (1398-05-16, Tordesillas), fol. 511v.

209 Sobre la versión castellana de la obra véase: AA.VV.: Los manuscritos de la versión castellana del De regimine principum de Gil de Roma, Tordesillas, 2003; DíEz Garretas, M.J; FradeJas RuEdA, J.M.; ACERo DurÁNTEZ, I.: "Las versiones A y B de la traducción castellana del De regimine principum de Gil de Roma", en Actas del IX Congreso Internacional de la Asociación Hispánica de Literatura Medieval, Noia (A Coruña), 2005, vol. 1, pp. 227-234; Álvarez TurIEnzo, S.: "El tratado De regime principum, de Egidio Romano, y su presencia en la Baja Edad Media hispana”, Cuadernos Salmantinos de Filosofía, 22 (1995), pp. 7-25; Beneyto PÉrez, J. (ed.): Glosa castellana al Regimiento de príncipes de Egidio Romano, Madrid, 2005. Existe, con la signatura BNE, Manuscritos, Mss. 9236, un ejemplar latino con decoración marginal parisina de fines del siglo XIII y miniatura valenciana de inicios del siglo XV, que pudo llegar a la corte castellana en los primeros años del siglo XV, cuando se añadieron las armerías reales, en fol. 7r. Sobre dicho ejemplar véase: YARzA LuACES, J.: La nobleza ante el rey. Los grandes linajes castellanos y el arte en el siglo XV, Madrid, 2003, pp. 293-295; PlanAs, J.: "Un ejemplar del Regimine principum de Egidio Romano en la biblioteca de Pedro Fernández de Velasco, Conde de Haro", Ephialte. Lecturas de Historia del Arte, 4 (1994), pp. 130-141.

${ }^{210}$ Biblioteca del Real Monasterio de San Lorenzo de El Escorial (B. Esc.), f-III-3 y f-III-4. Sobre la traducciones de De Regno de Tomás de Aquino y la cronología de los ejemplares escurialenses, véase: Nogales Rincón, D.: "En torno a la sabiduría en el cuatrocientos castellano: el prólogo a la traducción castellana del De regno ad regem Cypri de Tomas de Aquino dirigida a Fernando el Católico", Memorabilia: Boletín de Literatura Sapiencial, 12 (2009-2010), pp. 289-350, pp. 298-299; RodríGUEZ VELASCO, J.: El debate sobre la caballería en el siglo XV. La tratadística caballeresca castellana en su marco europeo, Valladolid, 1996, pp. 104-107, 415-416; Gómez Redondo, F.: Historia de la prosa medieval castellana. II. El desarrollo de los géneros. La ficción caballeresca y el orden religioso, Madrid, 1999, pp. 1700-1703. Adicionalmente, junto a estos ejemplares escurialenses, tenemos constancia de que, en la primera mitad del siglo XV, la reina María de Aragón, mujer de Juan II de Castilla, hubo de contar, entre las pertenencias de su cámara, con un ejemplar de esta obra. Cf. Pelaz Flores, D.: "Lujo, refinamiento y poder. La cámara de la reina María de Aragón (1420-1445)", en Estudios recientes de jóvenes medievalistas. Lorca 2012, Murcia, 2013, pp. 111-125, p. 120. 
Romano- formando parte de los bienes de la cámara se encuentra en sintonía con las informaciones puntuales que sobre la educación regia a fines del siglo XIV conocemos, cuyas bases teóricas se asentaría sobre estos regimientos de príncipes y sobre la cronística $^{211}$. El papel de las crónicas como modelo para la educación regia-puesto de relieve, ya para el siglo XV, por Lope García de Salazar ${ }^{212}$, Juan Alfonso de Baena ${ }^{213}$, Íñigo López de Mendoza ${ }^{214} \mathrm{o}$ Diego de Valera ${ }^{215}$ - parece haberse ido perfilando a lo largo de todo el período bajomedieval, presentándose como consolidado, de una forma claramente perceptible, a finales del siglo XIV. En dicha consolidación hubo de tener un papel fundamental la importancia didáctica concedida al exemplum, recurso que habría de ser entendido, en palabras de Germán Orduna, como "caso o narración probatoria", nacida de las lecturas o de la experiencia personal ${ }^{216}$. Este interés por el exemplum -en este caso, el específicamente histórico, presente en el relato cronístico de una forma explícita o implícita- no era ajeno a su protagonismo en las prácticas de predicación, al propio modelo literario de los regimientos de príncipes, que concedía especial importancia al hecho histórico como recurso didáctico, y al mismo interés por la materia histórica, personificada primordialmente en la atención por las crónicas y los sumarios de crónicas dentro de los círculos aristocráticos castellanos de fines de la Edad Media. Del interés por las crónicas como elemento fundamental de la educación real y de la orientación de la acción política regia tenemos buena muestra en el pasaje, incluido en la Crónica de Juan I de Pero López de Ayala, que narra cómo los miembros del Consejo Real, dirigiéndose al monarca para aconsejarle en 1390 sobre su proyecto de partición del reino, le habrían recordado las nefastas consecuencias derivadas de tal hecho, como "vos sabedes por Corónicas é libros de

211 "Betiza e Egica dos rreyos godos fueron, / de muy mal rregimiento e así se mantovieron; / luego los sus privados aquella ley seguieron: / la c(o)rónica lo cuenta, todos quál fin ovieron./ Quál rregimiento deven los prínçipes tener / es escripto en los libros que solemos leer; / Egidio [el] rromano, omne de grant saber, en Rregimine prinçipum, lo fue bien conponer. / Non curo de escrivirlo, pues ý lo fallarás; / mejor que lo diría, allí lo tú verás; / nobles enseñamientos, que plazar tomarás; / por ende de dezirlo, escusado me avrás", López de Ayala, P.: Rimado de palacio, coplas 637-639, pp. 241-243. Dicha corónica, como señala Hugo Óscar Bizzarri, es "la Estoria de España alfonsí (caps. 543-552), donde se cuenta la historia de ambos reyes", López de Ayala, P.: Rimado de Palacio, Real Academia Española, ed. de H.Ó. Bizzarri, Madrid, 2012, p. 104, nota 637.

212 Título de quáles fechos e esforçados deven leer en los libros d'ellos, GARcía DE SALAzAR, L.: Istoria de las bienandanzas e fortunas, ed. de A.M. Marín Sánchez, Madrid, 2000 en Real Academia Española, Banco de datos (CORDE) [en línea]. Corpus Diacrónico del Español. URL: <http://www.rae. es> [fecha de consulta: 2013-06-30].

213 Dutton, B.; González Cuenca, J. (eds.): Cancionero..., p. 5.

${ }^{214}$ López de Mendoza, Í. [Marqués de Santillana]: Proverbios o Centiloquio, en Obras completas, ed. de Á. Gómez Moreno y M.P.A.M. Kerkhof, Barcelona, 1988, p. 226.

215 Valera, D. de: Epístola que envió a Enrique IV (1462-07-1462, Palencia) en M. Penna (ed.): Prosistas castellanos del siglo XV. I, Madrid, 1959, epístola IV, p. 9; VALERA, D. de: Epístola que envió a los Reyes Católicos (1482-04-10, Puerto de Santa María) en M. Penna (ed.): Prosistas ..., epístola XVIII, pp. 23-24; VAlera, D. de: Crónica abreviada de España, prólogo, p. 19, con un análisis al respecto en Moya García, C.: "El Doctrinal de príncipes y la Valeriana: didactismo y ejemplaridad en la obra de mosén Diego de Valera”, Memorabilia, 13 (2011), pp. 231-243.

216 OrdunA, G.: "La ejemplaridad como recurso narrativo en las Crónicas del Canciller Ayala", Diablotexto: Revista de Critica Literaria, 3 (1996), pp. 187-198, p. 188. 
los fechos de España que son en la vuestra cámara, e los leen delante vos quando a la vuestra merced place" 217 .

A este modelo didáctico básico, basado en la lectura de los regimientos de príncipes y de las crónicas, hubieron de sumarse otros recursos complementarios, bajo la forma de sendas traducciones, dirigidas a Enrique III: por un lado, de la obra histórica Décadas, de Tito Livio, en palabras de Jesús Rodríguez Velasco, "paradigma militar y caballeresco" medieval, traducción abordada por el referido López de Ayala entre los años 1396-1400218; y, por otro lado, del tratado militar Epitoma rei militaris, de Flavio Renato Vegecio, vertido al castellano entre 1396 y 1406 por fray Alfonso de San Cristóbal ${ }^{219}$.

A su vez, la doctrina transmitida por este conjunto de obras dirigidas a asegurar el adecuado desempeño del ministerio regio sería capaz de crear un modelo didáctico paralelo, susceptible de ser aprovechado por la aristocracia desde una doble dirección. Por un lado, en una perspectiva política, cifrada principalmente en las funciones de consejo, como muestra el prólogo de la Suma de crónicas $^{220}$ o algún pasaje de la Crónica de Juan I'21, ya referido, o de la Crónica de Enrique III'22. Por otro lado, en una perspectiva militar, en sintonía con el prólogo de López de Ayala a las Décadas ${ }^{223}$ y las propias motivaciones que hubieron de conducir a la traducción tanto de las referidas Décadas como de Epitoma rei militaris, estrechamente relacionadas con la definición del papel militar de la nobleza, quizás no ajenas a las propias reformas llevadas a cabo por Juan I de Castilla tanto a nivel militar, principalmente por medio del plan esbozado en las Cortes de Briviesca de 1387 y del conocido como Ordenamiento de lanzas, dado en las Cortes de Guadalajara de 1390, como a nivel de las relaciones entre los súbditos y la Corona, sistematizadas en las Cortes de Segovia de 1386, en relación directa con la problemática de la derrota castellana en la batalla de Aljubarrota (1385) y la entrada en Castilla de Juan de Gante, duque de Lancaster (1386).

${ }^{217}$ López de Ayala, P.: Crónica del rey don Juan, primero de Castilla e de León, en C. Rosell (ed.): Crónicas..., vol. II, año 1390, cap. II, p. 126.

218 Gómez Redondo, F.: Historia de la prosa...III, pp. 2135-2142; Rodríguez Velasco, J.: El debate sobre la caballería..., pp. 414-415; Wittlin, C.J.: "Introducción”, en P. López de Ayala: Las Décadas de Tito Livio, Barcelona, 1982, t. I, pp. 11-211.

219 Sobre este véase Rodríguez Velasco, J.: El debate sobre la caballería..., pp. 418-419; FradEJAS RuedA, J.M.: "Prolegómenos a una edición crítica de la versión medieval castellana de Alfonso de San Cristóbal de la Epitoma rei militaris de Vegecio", Revista de Literatura Medieval, 23 (2011), pp. 153178; Roca Barea, M.E.: "El Libro de la Guerra y la traducción de Vegecio por Fray Alfonso de San Cristóbal", Anuario de Estudios Medievales, 37:1 (2007), pp. 267-304.

${ }^{220}$ Compendio de crónicas de reyes del Antiguo Testamento, gentiles, cónsules y emperadores romanos, reyes godos y de los reinos de Castilla, Aragón, Navarra y Portugal, BNE, Manuscritos, Mss. 7415 , fol. $4 \mathrm{r}$.

221 López de Ayala, P.: Crónica del rey don Juan, primero..., año 1390, cap. II, pp. 126-129.

222 López de Ayala, P.: Crónica del rey don Enrique Tercero..., año 1394, cap. X, p. 222.

${ }^{223}$ López de Ayala, P.: Las Décadas de Tito Livio, ed. de C.J. Wittlin, Barcelona, 1982, t. I, Dedicatoria, 21-23, pp. 219-220. 


\subsection{UN ANILLO SIGILAR DE ENRIQUE III: SOBRE UNA PRÁCTICA EN LA CANCILLERÍA REGIA Y LA CIMERA DEL GRIFO DE LOS REYES DE CASTILLA}

E1 29 de mayo de 1398 el camarero Pedro Fernández hubo de entregar "una sortija de oro gruesa para seellar, e está ençima de ella un escudo a las armas del dicho señor Rey, e ençima del escudo está hun yelmo, e ençima del yelmo está una cabeça de grifo, la qual llevó Ýñigo Lópes, camarero del dicho señor Rey, de Oterdesillas a Çamora"224. Se trata de lo que Antonio de Nebrija refiere como "annulus signatorius" o "anillo para sellar" 225 , es decir, el "sello en forma de anillo o sortija"226, que, como señala Ángel Riesco Terrero, se podría relacionar con "el sello o sellos secretos y personalísimos del rey empleados en asuntos delicados, privados y muy personales" 227 . La custodia de este sello, como, en efecto, muestra la Relación de efectos, correspondería, como refiere el citado Riesco Terrero, "no al chanciller o protonotario, sino al propio rey, al camarlengo o a alguno de sus secretarios más íntimos"228.

Este tipo de sellos personales (sellos secretos, signetes) hubieron de experimentar, a fines de la Edad Media, un cierto resurgir, en palabras de Faustino Menéndez Pidal, "entre quienes disponían de una cancillería, como reacción también ante su alejamiento de los otros sellos, que resultaban más unidos a la dignidad ostentada que a la propia individualidad" 229 . De hecho, no parece que se trate este de un sello característico o privativo de las prácticas de la cancillería real durante el reinado de Enrique III, pues tanto el arzobispo Pedro Tenorio en $1398^{230}$, como su nieto, Enrique IV de Castilla en 1465, hubieron de disponer igualmente de sortijas para sellar, quizá no muy diferentes a esta de Enrique III'231.

Es bastante probable que fuera su condición de sello personalísimo del monarca lo que explicara que las armerías reales de Castilla y León se encontraran coronadas por la figura de un grifo. Dicha cimera hubo de ser adoptada por Enrique II de Castilla y

${ }^{224}$ Relación..., (1398-05-29, Tordesillas), fol. 512r.

${ }^{225}$ Nebrija, A. de: Dictionarium Aelii Antonii Nebrissensis grammatici, Lyon, 1655, p. 489.

${ }^{226}$ Riesco Terrero, Á.: Introducción a la sigilografía, Madrid, 1978, p. 78.

${ }^{227}$ Riesco Terrero, Á.: Introducción...,, p. 78.

${ }^{228}$ Riesco Terrero, Á.: Introducción..., p. 78.

${ }^{229}$ Menéndez Pidal, F.: Heráldica de la Casa Real de León y de Castilla (siglos XII-XVI), Madrid, 2011, p. 290.

230 "Primeramente una sortija de oro encajada cō un camafeo blanco, tiene en él una figura de homen, e tiene otras tres piedras pequeñuelas de redor del verdugo, en la caxadura de plata, con otras figuras para sellar (...). Otro anillo de oro con una piedra amarilla topaça, en que está una figura de cabeça de home, cavada para sellar (...). Otro anillo viejo de oro, con una piedra cornelina, que tiene una figura de cabeça de home, para sellar. Otro anillo de oro con una piedra çafir, en que está una figura de cabeça de Obispo con su mitra, con que ahora sellan nuestras cartas mensajeras", Testamento de Pedro Tenorio (1398-11-04, Alcalá de Henares) en NARBOnA, E.: Historia de D. Pedro Tenorio, arçobispo de Toledo, Toledo, 1624, lib. II, fols. $128 \mathrm{v}-129 \mathrm{r}$.

231 "una sortija de oro con las armas reales, que pesó 5 doblas y media y 6 granos", Carta de pago que hizo Francisco de Tordesillas, camarero del rey, declarando haber recibido diversos dineros y una sortija de oro de Rodrigo de Tordesillas (1465-07-18) cit. en Ladero Quesada, M.Á.; CANTERA MonTENEGRo, M.: "El tesoro de Enrique IV en el alcázar de Segovia (1465-1475)", Historia. Instituciones. Documentos, 31 (2004), pp. 307-352, p. 332. 
el infante Juan, futuro rey Castilla, a la manera que se representa en la tabla conocida como la Virgen de Tobed ${ }^{232}$, habiendo tenido su uso continuidad durante el reinado de Juan I de Castilla, como muestra el Armorial de Gelre ${ }^{233}$. Aunque las circunstancias de la adopción del grifo por los Trastámara son desconocidas, cabría pensar, en atención a la cronología de ca. 1359 que se ha venido dando al referido retablo de la Virgen de Tobed ${ }^{234}$, que la adopción de la cimera hubiera tenido lugar en contacto directo con el entorno de la corte aragonesa, quizás adoptando un animal prestigioso que estéticamente se pareciera a la cimera del dragón de los reyes de Aragón, adoptada por Pedro IV ${ }^{235}$, y que aludiera simultáneamente, por su carácter híbrido, al león real de Castilla. En cualquier caso, como ha apuntado Faustino Menéndez Pidal, "la figura del grifo es de origen exterior, llegada a través de Navarra y Aragón, donde ya se estaban usando como armas desde mediados del siglo XIV, cuando menos" ${ }^{236}$.

Atendiendo a la capacidad de los emblemas heráldicos y divisas para mudar, con cierta facilidad, atendiendo a intereses diversos, su significado ${ }^{237}$, no cabe pensar que necesariamente la adopción del grifo por parte de Enrique II revistiera la dimensión religiosa que el Ordenamiento de la Orden de la Jarra y el Grifo ${ }^{238}$, orden fundada por el hermano de Enrique III, el infante Fernando de Antequera ${ }^{239}$, le otorgaría después,

232 Virgen de Tobed (ca. 1359), Jaume Serra. Témpera sobre tabla, 161,4 x 117,8 x $14 \mathrm{~cm}$. Madrid, Museo Nacional del Prado, Donación de Várez Fisa, procedente del santuario de Nuestra Señora de Tobed (Zaragoza).

${ }^{233}$ Menéndez Pidal, F.: El escudo..., p. 93; GonzÁlez Díez, E.; Martínez Llorente, F. J.: El blasón heráldico de los reinos de León y Castilla, Valladolid, 2002, p. 228.

234 Piquero López, B.: “187. Virgen de Tobed”, en Maravillas de la España medieval. Tesoro sagrado y monarquía, Valladolid, 2001, vol. I, pp. 443-445.

235 Sobre esta véase: FATÁs, G.: “El escudo de Aragón”, en Aragón. Reino y Corona, Zaragoza, 2000, pp. 167-174, p. 174; Montaner Frutos, A.: El señal del rey de Aragón: historia y significado, Zaragoza, 1995, pp. 59-60; MenÉndez Pidal, F.: El escudo..., p. 150.

${ }^{236}$ MenÉndez Pidal, F.: Heráldica..., p. 288.

${ }^{237}$ Sobre la significación del grifo y su polivalencia simbólica se pueden encontrar algunas referencias en: Walter, P.: "Hervis de Metz: le griffon et la fee", Vox Romanica, 45 (1986), pp. 157-167, pp. 165-166; Montero Curiel, P.; Montero Curiel, M.L.: El léxico animal en el Cancionero de Baena, Madrid, Fráncfort del Meno, 2005, pp. 324-326; AcostA, V.: Animales e imaginario. La zoología maravillosa medieval, Caracas, 1995, pp. 303-307; MALAXECHEVERríA, I.: Bestiario medieval, Madrid, 1999, pp. 138-143; Charbonneau-Lassay, L.: El bestiario de Cristo. El simbolismo animal en la Antigüedad y la Edad Media, Palma de Mallorca, 1996, t. I, pp. 364-377, pudiéndose hallar una interpretación alternativa del grifo, como animal simbólico del Islam, en el banquete que tuvo ocasión tras la coronación de Fernando I de Aragón, en MacKay, A.: "Don Fernando de Antequera y la Virgen Santa María", en Homenaje Juan Torres Fontes, Murcia, 1987, t. II, pp. 949-957, p. 955, sin olvidar otras posibles interpretaciones político-religiosas complementarias, apuntadas por Álvaro Fernández de Córdova Miralles en el trabajo que nos precede.

238 “del qual collar viene un griffo colgado en significación que (....) ansý todos los de la dicha devisa deven ser fuertes e firmes en el amor de Dios e de la Virgen Sancta María e esso mesmo en las obras de la cavallería", Ordenamiento de la Orden de la Jarra y el Grifo (1403-08-15, Medina del Campo), B. Esc. d-III-25, fols. 250v-251r.

239 Sobre la Orden de la Jarra véanse los apuntes recogidos en: Torres FonTES, J.: "Don Fernando de Antequera y la romántica caballeresca", Miscelánea Medieval Murciana, 5 (1980), pp. 83-120; MACKAY, A.: "Don Fernando de Antequera y la Virgen...", pp. 949-957; Dormer, D.J.: Discursos varios de Historia, con muchas escrituras reales antiguas, y notas de algunas dellas, Zaragoza, 1683, pp. 177197; Atienza y Navajas, J. de: "La Antigua Orden de Nuestra Señora del Lirio (año 1043)", en La obra 
y que, sin embargo, de forma más verosímil, pudiera relacionarse con la dimensión natural superior que el referido ordenamiento otorgaba a este animal fantástico, como ser "fuerte sobre todos los animales brutos" ${ }^{240}$. El empleo de esta cimera del grifo por los reyes de Castilla no tuvo continuidad, sin embargo, más allá del reinado de Enrique III, al ser sustituido durante el reinado de su hijo, Juan II de Castilla, por "un castillo del que sale medio león coronado" ${ }^{241}$, en un probable intento del rey castellano por diferenciarse de la rama aragonesa que, con la entronización de Fernando de Antequera como monarca de la Corona de Aragón, en 1412, haría suyo simbólicamente al grifo ${ }^{242}$ bajo la forma de la referida divisa de la Jarra y el Grifo, empleada como distinción real, y como tenante de las armas personales del nuevo rey ${ }^{243}$, más que quizá, como ha señalado Faustino Menéndez Pidal, a una cuestión de preferencia por "una cimera realista, mucho más conforme con los gustos castellanos" ${ }^{244}$.

\subsection{DOS JUGLARES DEL REY DE ARAGÓN EN CASTILLA: EL CAMBIO POÉTICO Y MUSICAL EN LA CORTE DE ENRIQUE III}

La corte de Castilla acogía en julio de 1398 a "Pifere e maestre Juan, juglares del Rey de Aragón", quienes recibieron de Enrique III dos hopas de paño de seda morisco, "la una verde e la otra azul pintadilla, con sus vandas de çintas de oro anchas de tres dedos et aforradas en çendal colorado e verde" ${ }^{245}$. Estos dos juglares cabe identificarlos con los ministriles de los reyes Juan I (1387-1396) y Martín I de Aragón (1396-1410), referidos en la documentación aragonesa con los nombres

de Julio de Atienza y Navajas, barón de Cobos de Belchite y marqués del Vado Glorioso en "Hidalgía", Madrid, 1993, pp. 13-18; TAdeo Villanueva, L.: "La orden española de caballería de la Jarra", Boletín de la Real Academia de la Historia, 75 (1919), pp. 68-76; GonzÁlez DÁvila, G.: Historia de la vida y hechos del rey don Henrique tercero de Castilla, Madrid, 1637, cap. LXXII, pp. 179-180; MenÉNDEZ Pidal, F., El escudo..., pp. 158-159.

240 Ordenamiento de la Orden de la Jarra y el Grifo (1403-08-15, Medina del Campo), BNE, Manuscritos, Mss. 18636/19, fol. 1r, con la variante "fuerte sobre todas las otras animalias" en el ejemplar del Ordenamiento B. Esc., d-III-25, fols. 250v-251r.

${ }^{241}$ Menéndez Pidal, F.: El escudo..., p. 96, con apuntes adicionales en MenÉndez Pidal, F.: Heráldica..., p. 310 .

${ }^{242}$ Cabe apuntar que la adopción por Fernando de Antequera del grifo como animal simbólico y su incorporación al collar de la Orden de la Jarra no sería ajeno a la primitiva cimera de los reyes de Casti1la. De hecho, cabe pensar que la incorporación del grifo al collar era un elemento complementario que, en el plano simbólico, potenciaba, pero en el que no se substanciaba, la verdadera esencia mariana de la orden, si atendemos a las referencias al "collar por devisa de las sus jarras de la Salutaçión, del qual collar viene un griffo colgado" o a la divisa "de la Jarra", y que, en el plano estético, permitía asimilarlo al diseño de los collares de otras órdenes de caballería del momento. Cf. Ordenamiento de la Orden de la Jarra y el Grifo (1403-08-15, Medina del Campo), B. Esc., d-III-25, fol. 250v; García de SANTA María, A.: Crónica de Juan II..., cap. 77, p. 173; García de SAnTA María, A.: Crónica de Juan II..., cap. 78, p. 174; Don Fernando de Antequera al concejo de Sevilla y a todas las ciudades del reino prohibiendo el uso indebido de diversas divisas (1410-12-04, Sevilla), Archivo Municipal de Murcia, Cartas, 13911412, fols. 138-139, en Torres Fontes, J.: "Don Fernando de Antequera...”, doc. 2, p. 119.

${ }^{243}$ Menéndez Pidal, F.: El escudo..., p. 155; Menéndez Pidal, F.: Heráldica..., pp. 347-348.

${ }^{244}$ Menéndez Pidal, F.: Heráldica..., pp. 287-288.

${ }^{245}$ Relación..., (1398-07-¿15?, Toro), fol. 513v, con referencia a estas igualmente en Relación..., (1398-07-08, Toro), fol. 513v; Relación..., (1398-07-09, Toro), fol. 513v. 
de Piffet $^{246}$ y maestre Johan ${ }^{247}$, quienes ejercerían, respectivamente, las funciones de bombarda y ministril de instrumento alto. Gracias a la documentación aragonesa es posible delimitar, a pesar del carácter polisémico del término juglar (funciones musicales, literarias, acrobáticas, etc. ${ }^{248}$, el perfil estrictamente musical de ambos juglares y específicamente, dentro de tales cometidos, su condición de instrumentistas. En este sentido, denominación y funciones siguen la tendencia general documentada para las cortes navarra o aragonesa, conforme a la cual, a partir de los años finales del siglo XIV y los iniciales del siglo XV, los juglares habrían ido ejerciendo, dentro del ámbito musical, preferentemente tareas de ejecución instrumental, por cuanto, al aumentar la complejidad musical, las funciones vocales habrían ido recayendo en cargos especializados: los cantores ${ }^{249}$.

La presencia de estos cargos musicales aragoneses en la corte castellana no es fruto de la casualidad. Por el contrario, se enmarcaría dentro de la práctica tardomedieval que regía las relaciones políticas entre reinos: el envío de cargos musicales a las cortes vecinas como instrumento auxiliar de las relaciones estrictamente diplomáticas. Dicha práctica, bien conocida en el ámbito castellano de fines del trescientos -con diversos intercambios documentados entre las cortes castellana y aragonesa; más eventuales con la navarra ${ }^{250}$, hubo de ser un elemento de un interés no menor en los procesos de difusión de las novedades musicales entre las cortes ibéricas, en un momento que precisamente se presenta como de transición tanto a nivel poético como musical. En el plano de la poesía cancioneril (donde junto a las cançiones y cantigas

246 Gómez Muntané, M. C.: La música en la Casa Real catalano-aragonesa durante los años 13361432. Vol. 1, Historia y Documentos, Barcelona, 1979, pp. 38-39, 41, 43-44 y docs. 91, 93, 96 у 108; Gómez Muntané, M.C.: El manuscrito M 971 de la Biblioteca de Catalunya (Misa de Barcelona), Barcelona, 1989, pp. 6, 8, 11 .

${ }^{247}$ Gómez Muntané, M.C.: La música...., pp. 43-44; Gómez Muntané, M.C.: El manuscrito ..., pp. 6,11 .

248 MenÉndez Pidal, R.: Poesía juglaresca y juglares. Orígenes de las literaturas románicas, Madrid, $9^{a}$ ed. ampliada, 1991, pp. 25-85. Sobre estos problemas terminológicos relativos al término juglar y su sustitución por la denominación de ministril, véase Menéndez Pidal, R.: Poesía juglaresca ..., pp. 41-42, 290, con apuntes para el caso navarro, donde la transición terminológica tiene lugar a fines del siglo XIV e inicios del siglo XV, cuando todavía se hace uso indistinto del término juglar y ministril, en Narbona CÁrceles, M.: "La consideración del juglar en la Corte de Carlos II y Carlos III de Navarra, a través del estudio de su atuendo", en Mito y realidad en la Historia de Navarra. Actas del IV Congreso de Historia de Navarra, Pamplona, 1998, t. I, pp. 429-442, p. 432; Cabanes Pecourt, M. de los D.: "Juglares navarros del siglo XIV", Saitabi: Revista de la Facultat de Geografia i Història, 13 (1963), pp. 61-66, pp. 61-62 y aragonés, donde dicha transición tiene lugar a mediados del siglo XIV, imponiéndose el término ministril a partir de la década de 1370-1380, en Gómez Muntané, M.C: La música..., pp. 26-27.

249 Gómez Muntané, M.C.: La música..., pp. 26-28; Narbona CÁrceles, M.: “La consideración del juglar...”, p. 431.

${ }^{250}$ Cañas Gálvez, F. de P.: "La Casa de Juan I...”, pp. 159-160, con apuntes más generales sobre el proceso en CAÑas Gálvez, F. de P.: "Música, poder y monarquía en la Castilla trastámara (1366-1474). Nuevas perspectivas de análisis", Revista de Musicología, 32:1 (2009), pp. 359-378, pp. 364-366, y para la corte de Juan II y Enrique IV, respectivamente en CAÑAS Gálvez, F. de P.: "La música en la corte de Juan II de Castilla (1406-1454). Nuevas fuentes para su estudio", Revista de Musicología, 23:2 (2000), pp. 367-394, pp. 375-377 y Cañas Gálvez, F. de P.: "La música en la Corte de Enrique IV de Castilla (1454-1474). Una aproximación institucional y prosopográfica”, Revista de Musicología, 29:1 (2006), p. 217-313, pp. 263-265. 
musicadas coexisten formas poéticas a priori no musicales, como los dezires), es posible considerar, bajo el influjo francés e italiano, el reinado de Enrique III como un momento-representado por buena parte de los poetas reunidos en el Cancionero de $B a e n a^{251}$ - de transición a nivel de géneros, técnicas y lenguaje, durante el cual "fasta estos nuestros tiempos", como indicaría hacia 1449 el Marqués de Santillana en su Proemio e carta, "se començó a elevar más esta sçiençia e con mayor elegançia" 252. En el campo estrictamente musical, se observa un intento por adherirse a las corrientes internacionales, siendo posible, al menos, desde estos momentos, documentar la presencia de cantores formando parte de la capilla real castellana $a^{253} \mathrm{y}$ de algunos otros que, estando formalmente al servicio de Carlos III de Navarra ${ }^{254}$, residían temporalmente durante el año 1399 en la corte de Castilla, habiéndose documentado, no casualmente, en estos precisos momentos, según Tess Knighton, diversos testimonios escritos que "bear witness to the presence, or at the very least knowledge, of Frenchtexted polyphonic song in Castile from at least 1400"255.

${ }^{251}$ Sobre los poetas de la corte de Enrique III, véase Perea Rodríguez, Ó.: La época del Cancionero de Baena: los Trastámara y sus poetas, Baena, 2009, pp. 147-185; Beltrán, V.: Poesía española. Vol. 2. Edad Media: lírica y cancioneros, Barcelona, 2002, pp. 171-260.

${ }^{252}$ López de Mendoza, Í. [Marqués de Santillana]: "Proemio", en Obras completas, pp. 451-452. Proceso que, entre otros aspectos, hubo de culminar el abandono del portugués como lengua poética a favor del castellano y supuso una evolución hacia modas francesas e italianas, un interés por los dezires didácticos y los juegos de preguntas y respuestas, a costa de la lírica amatoria, con una desaparición completa de las cantigas de amigo, y una mayor atención por temas filosóficos, teológicos, morales y políticos. Algunas orientaciones generales sobre estos aspectos en Pérez Priego, M.Á.: "Los cancioneros poéticos castellanos del siglo XV", en Estudios sobre la poesía del siglo XV, Madrid, 2004, pp. 11-26; López Estrada, F.; López García-Berdoy, M.T.: Poesía castellana de la Edad Media, Madrid, 1991, pp. 207-212; LAPESA, R.: "La lengua de la poesía lírica desde Macías hasta Villasandino", Romance Philology, 7 (1953), pp. 51-59; Gimeno Casalduero, J.: "Pero López de Ayala y el cambio poético de Castilla a comienzos del XV", Hispanic Review, 33 (1965), pp. 1-14; Deyermond, A.: "Baena, Santillana, Resende and the Silent Century of Portuguese Court Poetry", Bulletin of Hispanic Studies, 59:3 (1982), pp. 198-210, pp. 203-204; Beltrán, V.: Poesía..., pp. 21-56.

${ }^{253}$ Nogales Rincón, D.: La representación religiosa de la monarquía castellano-leonesa. La Capilla Real (1252-1504), tesis doctoral inédita leída en la Universidad Complutense de Madrid. Facultad de Geografía e Historia. Departamento de Historia Medieval, Madrid, 2009, pp. 2017-2018, 2048, 2205, 2206.

${ }^{254}$ Estamos pensado en Johan Gornay, enviado por el rey de Navarra en febrero de 1399, quien, a su vez, se había dirigido a la corte de Castilla en busca de otro chantre del rey de Navarra, que había caído enfermo. Cf. Carlos III ordena a los oidores de comptos que reciban en cuenta y deduzcan de la recepta de Johan Caritat, tesorero del reino, entre otros, 12 florines a Johan Gornay, chantre de su capilla, por sus expensas en ir a la corte del rey de Castilla (1399-02-07, Peralta), Archivo General de Navarra (AGN), Sección de Comptos (Comptos), caja 76, nº 5, V reg. en RAMÓN CASTRO, J.: Catálogo de la Sección de Comptos. Documentos. Tomo XXIII. Años 1399-1400, Pamplona, 1959, doc. 55, pp. 32-33; Huguet, chantre del rey, reconoce que ha recibido 12 florines para enviarlos a Gournay, el cual fue a Castilla en busca de otro chantre (1399-02-22), AGN, Comptos, caja 76, $\mathrm{n}^{\circ}$ 47, XXX reg. en CASTRO, J.: Catálogo..., doc. 78, p. 43; Gournay, chantre de la capilla, reconoce que ha recibido 4 florines para sus expensas en ir a Castilla en busca de otro chantre, más la misma cantidad por las expensas de este (1399-03-08), AGN, Comptos, caja 76, nº 47, XXXII reg. en CAStro, J.: Catálogo..., doc. 107, p. 54.

${ }^{255}$ Knighton, T.: "Isabel of Castile and Her Music Books: Franco-Flemish Song in Fifteenth-Century Spain", en Queen Isabel I of Castile. Power, Patronage, Persona, Woodbridge 2008, pp. 29-52, pp. 32-33. 


\section{EL REFLEJO DE LOS ACONTECIMIENTOS DE LA POLÍTICA INTER- NACIONAL ENTRE LOS AÑOS 1397-1398: EL FECHO DE LA GUERRA DE PORTUGAL}

El inicio de la década final del siglo XIV se había resuelto con un acuerdo de treguas entre las cortes castellana y portuguesa, firmadas el 15 de mayo de $1393^{256}$. Dichas treguas tuvieron efecto hasta 1396, cuando Juan I de Portugal reactivó el conflicto frente a Enrique III, al llevar a cabo un ataque a Badajoz, conquistada el 12 de mayo $^{257}$. Dicha conquista, como puntualiza César Olivera, "no se trataba de una invasión general como la de 1386, sino de golpes de mano en algunos puntos fronterizos, con el fin de ganar posiciones ante una futura negociación" 258 , buscando convertir la ciudad tomada, en palabras de Suárez Fernández, en "una excelente prenda de negociación" 259.

Se iniciaba así, en palabras de Luis Suárez Fernández, "el problema más importante de Enrique III a resolver en el desarrollo de su política exterior" ${ }^{260}$, el conflicto que Emilio Mitre ha denominado como "guerra abierta, aunque solo haya sido a pequeña escala" ${ }^{261}$ contra Juan I de Portugal, que se prolongaría, con una breve tregua en $1399^{262}$, hasta la firma de las treguas generales de $1402^{263}$. Habiendo sido abordado, en diversas ocasiones, este período ${ }^{264}, \mathrm{y}$ encontrándose una fuente detallada, aunque no siempre clara en la sucesión de los acontecimientos, en la Crónica de D. João I, de Fernão Lopes ${ }^{265}$, nos limitaremos a contextualizar algunas de las informaciones incluidas en la Relación de efectos.

Buena parte de los apuntes que ofrece la Relación para los meses de octubre, noviembre y diciembre de 1397 aluden al pago de sueldos, raciones, ayudas de mantenimiento, ayuda de costa, etc. para jinetes, omnes de pie, lanzas, escuderos de ca-

256 Sobre estas treguas véase: SuÁrez Fernández, L.: “Algunos datos...”, pp. 564-570; SuÁrez FERNÁNDEZ, L.: Relaciones entre Portugal y Castilla en la época del Infante don Enrique (1393-1460), Madrid, 1960, pp. 17-20.

257 SuÁrez Fernández, L.: “Algunos datos...”, p. 571; SuÁrez Bilbao, F.: Enrique III (1390-1406), Palencia, 1994, pp. 160-163; SuÁrez Fernández, L.: Relaciones..., pp. 20-21; Coelho, M.E. da C.: D. João I. O que re-colheu Boa Memória, Lisboa, 2005, p. 107.

258 Olivera Serrano, C.: Beatriz de Portugal. La pugna dinástica Avís-Trastámara, Santiago de Compostela, 2005, p. 122.

259 SuÁrez Fernández, L.: Relaciones..., p. 21.

260 SuÁRez FernÁndez, L.: “Algunos datos sobre política exterior de Enrique III”, Hispania: Revista Española de Historia, 40 (1950), pp. 539-597, p. 564.

261 Mitre Fernández, E.: "Notas sobre la ruptura castellano-portuguesa de 1396", Revista Portuguesa de História, 12 (1969), pp. 213-221, p. 213.

262 Beceiro Pita, I.: "Las negociaciones entre Castilla y Portugal en 1399", Revista da Faculdade de Letras. História, 13 (1996), pp. 149-186; SuÁrez Fernández, L.: Relaciones..., pp. 25-27; SuÁrez Bilbao, F.: Enrique III, pp. 182-183.

263 SuÁrez Fernández, L.: Relaciones..., pp. 27-29; Coelho, M.E. da C.: D. João I, p. 110; SuÁrez Bilbao, F.: Enrique III, pp. 185-186.

264 Arnaut, S.D.: A crise nacional dos fins do século XIV, Coimbra, 1959, pp. 245-257; Coelho, M.E. da C.: D. João I, pp. 107-111; Mitre Fernández, E.: "Notas sobre la ruptura...", passim; SuÁrez Bilbao, F.: Enrique III, pp. 155-187; SuÁrez Fernández, L.: Relaciones..., pp. 17-29; SuÁrez FernánDEZ, L.: "Algunos datos...", pp. 564-579.

${ }^{265}$ Lopes, F.: Crónica de D. João I, Oporto, 1983, vol. II, caps. CLIV-CLXXIII. 
ballo, ballesteros de maza o de ballesta y otros oficiales de la corte ${ }^{266}$, estando, por el contrario, las informaciones consignadas durante los primeros meses del año 1398 relacionadas preferentemente con la entrega de ballestas, de las que, en algún caso, tenemos certeza de que fueron empleadas en la guerra frente a Portugal ${ }^{267}$.

La Relación, complementando algunas de las informaciones conocidas, sugiere que el camarero y condestable de Castilla, Ruy López Dávalos, se había de encontrar en las cercanías con la frontera con Portugal a fines de agosto de 1397 -situado en esta posición probablemente para auxiliar a los maestres de Santiago y Alcántara, en el supuesto de que se produjera una entrada del condestable de Portugal, Nuno Álvares Pereira, en la Corona de Castilla ${ }^{268}$-, cuando Enrique III le remitió un jaque a Ciudad Rodrigo ${ }^{269}$; y que nuevamente, algunos meses después, en mayo de 1398, este se encontraría desarrollando diversas acciones en Portugal ${ }^{270}$, habiendo sido pagadas con cargo al camarero Pedro Fernández algunas de las tropas que lo acompañaron ${ }^{271}$. El protagonismo de López Dávalos en el fecho de la guerra de Portugal fue innegable -de él diría Fernán Pérez de Guzmán que "fizo en la guerra de Portugal notables actos de cavallería" ${ }^{72}$-, hasta el punto de perfilase, en palabras de Suárez Fernández, en "protagonista principal" del conflicto, hecho que favoreció un "ascenso prodigioso" del mismo ${ }^{273}$. Ello fue posible gracias a su participación, durante los primeros meses del conflicto, en el ataque, entrando "por el Alseda", a la villa portuguesa de $V^{V}$ iseu $^{274}$, al que se hubo de sumar, algunos meses después, la misión de descercar

${ }^{266}$ Relación..., fols. $501 \mathrm{v}-504 \mathrm{v}$.

${ }^{267}$ Relación..., fols. 507v, 509r, 510r, 511r-511v. Entre estas ballestas se encontraba "una vallesta, a que dezían la Real", remitida a Ruy López Dávalos; denominación que parece no ser un hecho particular, si atendemos a la existencia de "una famosa ballesta, e fuerte, que llamavan la Niña", en alusión a su propietario, Pero Niño. Cf. Díaz de Games, G.: El Victorial, cap. 39, p. 283.

${ }^{268}$ Carta de Enrique III a los maestres de Santiago y de Alcántara ([1397]-08-16, Bonilla de la Sierra), RAH, Colección Salazar y Castro, M-6, fol. 324r. Sobre la datación precisa de la carta, sin año, véase Veas Arteseros, F. de A.: Itinerario..., n $\mathrm{n}^{\circ} 1.290$.

269 "Levolo Fernando Álvares de Toledo a Çibdat Rrodrigo a Rruy Lópes", Relación..., (1397-0828, Bonilla de la Sierra), fol. 500r.

270 "En esta dicha villa sábado diez días del mes de mayo, dy yo Pero Ferrándes, por mandado del Rey, a Ruy Lópes de Dávalos, su camarero, diez e seys vallestas, las quales dichas diez e seys vallestas le yo enbié a Portogal, onde él estava en serviçio del Rey", Relación..., (1398-05-¿10?, Tordesillas), fol. 511 r.

271 "En esta dicha villa este dicho día, a Fernán Péres de Castelejo, sueldo de xx días para quatro lanças, quando fueron con Rruy Lópes", Relación..., (1397-12-11, Madrid), fol. 503v; "En este dicho lugar miércoles doze días de dezienbre, dy yo el dicho Pero Ferrándes, por mandado del Rey, a Antón Rrodrígues, escudero de Ruy Lópes, para que levase al dicho Ruy Lópes de sueldo para su gente, çinquenta mill”, Relación..., (1397-12-12, Madrid), fol. 504r.

272 Pérez de Guzmán, F.: Generaciones..., cap. IV, p. 89.

273 SuÁrez Fernández, L.: Nobleza y monarquía, p. 140.

274 "E don Ruy López levó la hueste del rey, e fue a Çiudad Rodrigo, e entró en Portugal por el Alseda, quemando e destruyendo. Llegó a la çiudad de Viseo, e entróla por fuerça", DíAz DE GAMES, G.: El Victorial, cap. 27, p. 248; "Ca si fuera en Viseo / e en muchos lugares ante, / viera el esfuerço e meneo, / fortaleza e buen semblante / del falcón, que es bastante", AlvÁrez de Villasandino, A.: Este dezir de Alfonso Álvarez contra un portogués (ID1218, año 1396) en B. Dutton; J. González Cuenca (eds.): Cancionero..., $\mathrm{n}^{\mathrm{o}} 76$, p. 103, vv. 10-12. La datación de este hecho es difícil de determinar con precisión, pues la ciudad parece que pudo ser objeto de diversos ataques a lo largo del conflicto, fruto de su situación en el centro del sistema de defensa militar de la Beira Alta y de su desprotección, como señala SARAIVA, 
sin éxito -a pesar de que la penetración portuguesa hacia el interior de Galicia fuera contenida- la ciudad de Tuy (Pontevedra), que se entregó a las tropas portuguesas el 25 de julio de $1398^{275}$.

Además del propio desarrollo de los acontecimientos, la Relación permite observar las relaciones de la corte castellana con algunos de los exiliados portugueses ${ }^{276}$. Las estrategias para la atracción de los mismos son claramente perceptibles en sus líneas generales, habiendo estado probablemente inspiradas, en buena medida, en las propias dinámicas de alianza política desarrolladas por los primeros Trastámaras: una generosa política de mercedes y un interés claro por el desarrollo de estrategias matrimoniales como instrumento para asegurar la posición social, económica y política de los aliados políticos, conforme al principio enunciado por Enrique III sobre que "pertenesçe al estado de los Reyes e de la su Realeza del enobleçer e onrrar e previlleiar a los sus vasallos que byen e lealmente le syrven e heredar los en sus Reynos" ${ }^{27}$. Tales estrategias hubieron de ser la base de la política de atracción desplegada por Enrique III para ganar para la causa castellana a diversos miembros de la nobleza portuguesa: el intento frustrado por atraer a Nuno Álvares Pereira ${ }^{278} \mathrm{y}$ las tentativas exi-

A.M. de S.: "Viseu no rastro da guerra: dos conflitos fernandinos à paz definitiva com Castela", en $A$ Guerra e a Sociedade na Idade Média. Actas das VI Jornadas Luso-Espanholas de Estudos Medievais, Torres Novas, 2009, Vol. 1, pp. 323-358, pp. 339-340. Parece, en línea con lo indicado en SARAIVA, A.M. de S.: "Viseu no rastro da guerra...", pp. 338, 341, siguiendo a Lopes, F.: Crónica de D. João I, vol. II, cap. CLIX, p. 347, que sería posible situar un posible ataque de Ruy López Dávalos poco después de la toma, el 12 de mayo de 1396, de Badajoz, como represalia por la toma de la ciudad, o quizá, de una forma hipotética, con ocasión de la incursión de Martín Vázquez de Acuña hasta Guarda y que llevó igualmente a Ruy López Dávalos al interior de Portugal, en junio de 1397, conforme a lo indicado en Carta de Enrique III al maestre de Santiago, Lorenzo Suárez de Figueroa ([1397]-06-28, Salamanca), RAH, Colección Salazar y Castro, M-6, fol. 322r; Carta de Enrique III al maestre de Santiago, Lorenzo Suárez de Figueroa ([1397]-07-26, Salamanca), RAH, Colección Salazar y Castro, M-6, fols. 321r$321 v$. Sobre la datación precisa de ambas carta, sin año, véase VeAs Arteseros, F. de A.: Itinerario..., nos. $1.283,1.285$.

275 "En aquel tienpo çercó el rey de Portugal la çiudad de Tuy, que es en Galiçia. El rey ayuntó su hueste, e enbióla con don Ruy López de Ávalos", Díaz de GAMEs, G.: El Victorial, cap. 29, p. 251. Cf. Coelho, M.E. da C.: D. João I, p. 110.

${ }^{276}$ Algunos apuntes sobre estos en Olivera Serrano, C.: "Linajes portugueses exiliados en Castilla a fines del siglo XIV", en España y América: un escenario común, Santiago de Compostela, 2005, pp. 481-486; Romero Portilla, P.: "Exiliados en Castilla en la segunda mitad del siglo XIV: origen del partido portugués", en Poder y sociedad en la Baja Edad Media hispánica: Estudios en Homenaje al Profesor Luis Vicente Díaz Martín, Valladolid, 2002, vol. I, pp. 519-539; Mitre Fernández, E.: "La emigración de nobles portugueses a Castilla a fines del s. XIV", Hispania: Revista Española de Historia, 104 (1966), pp. 513-525; Moreno, H.B.: "Exilados portugueses em Castela durante a crise dos finais do século XIV (1384-1388)", en Actas das II Jornadas Luso-Espanholas de História Medieval, Oporto, 1987, vol. I, pp. 69-101; Romero Portilla, P.: "El peso de la familia Acuña en el nacimiento del partido portugués", en Homenaje al profesor Eloy Benito, Murcia, 2010, t. II pp. 683-692; Fernandes, F.R.: "Os exílios da linhagem dos pacheco e sua relação com a natureza de suas vinculações aos Castro (segunda metade do século XIV)", Cuadernos de Historia de España, 82 (2008), pp. 31-54.

277 Carta de Enrique III confirmado la donación al infante don Juan de Portugal de Valencia (139202-20, Burgos), AGS, PR, leg. 58, doc. 85, en Arnaut, S.D.: A crise nacional..., doc. 111, p. 492.

278 "si vos vien leyérades el memorial que vos embié con Johan López, falláredes que yo non vos mandava tratar con Nuño Álvarez salvo con Gonçalo Yáñez de Casteldavit, el qual avía fablado algunas cosas con el Doctor Antón Sánchez expeçialmente del casamiento del Duque de Medinasidonia con fija del dicho Nuño Álvarez", Carta de Enrique III al maestre de Santiago, Lorenzo Suárez de Figueroa 
tosas que pusieron al servicio de los intereses castellanos a Martín Vázquez de Acuña (Martim Vasques da Cunha), su hermano Lope Vázquez de Acuña (Lopo Vasques da Cunha) ${ }^{279}$, Juan Alfonso Pimentel (João Afonso Pimentel) o Gil Vázquez de Acuña (Gil Vasques da Cunha) $)^{280}$, reforzadas dichas estrategias con la promesa de entregar futuros beneficios en el caso de que el candidato favorable a los intereses castellanos, el infante Dinis de Portugal, hijo del rey Pedro de Portugal, sobre el que hablaremos más adelante, pudiera convertirse en rey de Portugal ${ }^{281}$.

Entre las relaciones con los exiliados reflejadas en la Relación de efectos, cabe destacar, en primer lugar, la existente con el referido Martín Vázquez de Acuña, quien, refugiado en Castilla, junto con su hermano Lope Vázquez de Acuña, en los meses que siguieron a la ruptura de las treguas ${ }^{282}$, contraería matrimonio con María, hija mayor del infante Juan de Portugal ${ }^{283}$ y de la infanta Constanza Enríquez, vástagos respectivamente de Pedro I de Portugal y de Enrique II de Castilla; hecho que, en definitiva, aseguraba a Vázquez de Acuña entroncar con los descendientes de los reyes de Portugal y Castilla, además de permitirle acceder al título de conde de Valencia de don Juan. El interés político de este matrimonio estaba, por lo tanto, fuera de toda

([1397]-07-31, Salamanca), RAH, Colección Salazar y Castro, M-6, fol. 322v; "e el dicho Ynfante [D. Dionís] le fará [a Nuno Álvares Pereira] todas aquellas gracias y merçedes que el querrá en aquel Regno de Portogal e demás a mí echará muy grant carga e estó muy presto de le façer graçias, y mercedes acá en el Regno de Castiella de la figura que él queara e de casar y façer las bodas muy honrrosas a su fija con mi tío Don Enrrique sobredicho", Carta de Enrique III al maestre de Santiago, Lorenzo Suárez de Figueroa ([1397]-07-31, Salamanca), RAH, Colección Salazar y Castro, M-6, fol. 323v. Sobre la datación precisa de la carta, sin año, véase Veas Arteseros, F. de A.: Itinerario..., nº 1.286.

${ }^{279}$ Lopes, F.: Crónica de D. João I, vol. II, cap. CLVIII, p. 346.

${ }^{280}$ Tratado entre Diego López de Estúñiga, procurador del rey de Castilla y Juan Alfonso Pimentel (1398-03-04, Zamora), AHN, Sección Nobleza, Osuna, leg. 415, doc. 5, en Arnaut, S.D.: A crise nacional..., doc. 132, pp. 519-521.

${ }^{281}$ Lopes, F.: Crónica de D. João I, vol. II, cap. CLXX, p. 372; Lopes, F.: Crónica de D. João I, vol. II, cap. CLXXII, p. 378.

${ }^{282}$ Parece probable que la deserción del partido del rey Juan I de Portugal, a favor de Enrique III de Castilla, se estuviera negociando en torno a abril de 1397, siendo ya efectiva en junio de ese año, como parecen sugerir las palabras de Enrique III al referir, en una carta escrita en Madrigal -probablemente en torno al 17 abril de 1397, atendiendo a lo indicado en Veas Arteseros, F. de A.: Itinerario..., $\mathrm{n}^{\circ} 1.257$ el hecho de "cómo Martín Bázquez de Cuña, y sus Hermanos y parientes me querían servir", a la vez que aludiría, a fines de junio de ese año de 1397, que "luego se veno [Martín Vázquez de Acuña] para él [Ruy López Dávalos] allí a Cibdad [Rodrigo] el dicho Martín Bázquez, y Lope Bázquez su hermano y su fijo", Carta de Enrique III al maestre de Santiago, Lorenzo Suárez de Figueroa ([1397]-06-26, Salamanca), RAH, Salazar y Castro, M-6, fols. 321v-322r. Por el contrario, el cronista Fernão Lopes da a entender que la adhesión pudo tener lugar no mucho después de la toma de Badajoz: "E desta vimda que os ditos embaixadores vieram fallar a el Rey sobre esto que dizemos, amdamdo na Corte, moveram Martim Vasquez da Cunha e Lopo Vasquez", Lopes, F.: Crónica de D. João I, vol. II, cap. CLVIII, p. 346, habiéndose propuesto, en este sentido, como fecha de la salida de Portugal el año de 1396 en ARNaUt, S.D.: A crise nacional..., p. 245 y Romero Portilla, P.: Señores de dos reinos: los portugueses y el gobierno de Castilla en el siglo XV, La Coruña, 2011, pp. 143-144 ó 1397 en SuÁrez Fernández, L.: “Algunos datos...”, p. 572. El exilio de su hermano, Gil Vázquez de Acuña, hubo de tener lugar posteriormente, en 1398, pues sabemos que el 28 de enero de ese año Enrique III concedió poderes a Diego López de Estúñiga para tratar la ida de este y de Juan Alfonso Pimentel para Castilla. Cf. Arnaut, S.D.: A crise nacional..., p. 246.

${ }^{283}$ Una síntesis biográfica sobre este puede encontrarse en Olivera Serrano, C.: Beatriz de Portugal, pp. 286-290. 
duda, como vendría, de hecho, a apuntar Gutierre Díaz de Games, quien indicaría que "a la fija mayor casáronla con el conde don Martín Vázquez de Acuña, porque lo traxeron ansí con aquel trato, lo que trataron con él quando se pasó de Portugal a Castilla. E casáronla por fuerça, e contra voluntad de su madre, por mandado del rey" ${ }^{284}$. Según la Relación de efectos, con ocasión la celebración de las bodas, que hubieron de tener lugar probablemente a inicios de noviembre de 1397, Enrique III hubo de entregar diversas mercedes a los contrayentes: piezas de tela, forros de pieles, vestidos, "dineros" y dos sortijas de oro "para quando los velaron" 285 . La posibilidad de contar con Martín Vázquez de Acuña hubo de tener una importancia no menor para Enrique III, pues su protagonismo en el fecho de la guerra de Portugal fue destacado, al menos en ciertos momentos, tanto desde el punto de vista del diseño de la estrategia militar ${ }^{286}$, como desde el punto de vista político, gracias a su papel en la promoción política del infante Dinis. Martín Vázquez de Acuña estuvo presente en la acción militar que hubo de tener lugar en el mes de junio 1397287, en colaboración con su hermano, Lope Vázquez de Acuña y el hijo de este, cuando entraron, en defensa de la legitimidad del infante Dinis, en la región portuguesa de la Beira ${ }^{288}$, así como en la incursión que, al año siguiente, hubo de realizar en la misma región el infante Dinis, sobre la que hablaremos a continuación.

${ }^{284}$ Díaz de Games, G.: El Victorial, cap. 91, p. 482.

285 Relación..., (1397-11-02, Cantalapiedra), fol. 501v; Relación..., (1397-11-02, Cantalapiedra), fol. 501v; Relación..., (1397-11-04, Madrigal), fol. 501v; Relación..., (1397-11-04, Madrigal), fol. 502r.

286 “en cómo Ruy Lopes era entrado en Portogal con consejo de Martín Bázquez, por quanto les embiaron deçir que estavan en discordia en la çibdad de la Guarda e se querían acuchillar unos con otros", Carta de Enrique III al maestre de Santiago, Lorenzo Suárez de Figueroa ([1397]-06-28, Salamanca), RAH, Colección Salazar y Castro, M-6, fol. 322r; "emtramdo desta guissa pella Beira. (...) E este acordo dizem que foy por comselho de Martim Vasquez e dos outros portugueses que se pera la foram, dizemdo que naquella comarqua nã avia nenhun Fromteiro nem outra pessoa que lha defemder podese", LoPES, F.: Crónica de D. João I, vol. II, cap. CLXX, p. 373;

${ }^{287}$ Dicha entrada hubo de tener lugar antes del 26 de junio, cuando tuvo de ella noticia Enrique III.

288 “e que quería [Martín Vázquez de Acuña] embiar a Cibdad Rodrigo a Ruy López de Dávalos con alguna gente, el qual fue allá con fasta mil lanças, e luego se veno para él allí a Cibdad el dicho Martín Bázquez y Lope Bázquez su Hermano, y su fijo, e ayer martes ove rrecabdo çierto en cómo el dicho Ruy López es entrado en Portogal, y con él el dicho Martín Bázquez", Carta de Enrique III al maestre de Santiago, Lorenzo Suárez de Figueroa ([1397]-06-27, Salamanca), RAH, Colección Salazar y Castro, M-6, fol. 322r, con referencia a la datación precisa de la carta, sin año, en VeAs ArTESEROs, F. de A.: Itinerario..., n $n^{\circ}$ 1.282. En dicha incursión, Martín Vázquez de Acuña hubo de dirigirse, "con cierta compaña de la que iva con Ruy López", hacia la ciudad portuguesa de Guarda, "e los de la çibdad non les osaron fablar nin los acogieron por lo qual se ovieron de tornar", Carta de Enrique III al maestre de Santiago, Lorenzo Suárez de Figueroa ([1397]-06-28, Salamanca), RAH, Colección Salazar y Castro, M-6, fol. 322r. Debe ser este el mismo episodio que aparece relatado en otra carta, dirigida por Enrique III, al mismo maestre de Santiago: "Otrosi sabed que el Maestre de Calatrava y Ruy López y los otros cavalleros que entraron en Portogal con el Ynfante D. Donís son ya fuera, por quanto Juan Fernández Pacheco non quiso entregar la Guarda nin otrosí pieça de algunos cavalleros de aquella comarca, que estava conçertado que avían de tomar la boz por el dicho Ynfante, según las seguranças que sobre ello tenían puestas, y juradas non la quisieron tomar, nin quisieron tener lo que avían prometido, por lo qual se ovieron de tornar para Çibdat Rodrigo como quier que estudieron dentro en Portogal bien quinçe días y robaron y quemaron toda aquella tierra, y ficieron quanto mal y daño pudieron", Carta de Enrique III al maestre de Santiago, Lorenzo Suárez de Figueroa ([1397]-07-26, Salamanca), RAH, Colección Salazar y Castro, M-6, fols. 321r-321v. 
En segundo lugar, en lo relativo a las relaciones con los exiliados portugueses reflejadas en la Relación de efectos, cabe destacar la existente con el referido infante Dinis ${ }^{289}$, instrumentalizado por la corte de Enrique III como candidato al trono portugués favorable a los intereses castellanos. La atención despertada en la corte de Castilla por el infante portugués se encontraba, en opinión de César Olivera, en relación con su condición de varón de estirpe regia, capaz de ofrecer una alternativa castellana a las aspiraciones de Beatriz de Portugal, hija de Fernando I de Portugal y viuda de Juan I de Castilla, al trono luso ${ }^{290}$. En julio de 1397, desde el lado castellano, se argumentaba que al infante Dinis "perteneçe el regnado de Portogal", a la vez que era referido como "rey y señor natural, el qual de derecho es", en su condición de "fijo del rey D. Pedro, y de Doña Ynés [de Castro], con quien el Rey Don Pedro fue casado" 291 . A estos argumentos legitimadores, se hubo de sumar, algunos meses después, de ser cierto lo que nos cuenta el cronista Fernão Lopes, aquel otro que presentaba al infante Dinis como depositario de los derechos al trono portugués de la referida Beatriz de Portugal ${ }^{292}$. Paralelamente, la propaganda castellana buscó probar la naturaleza ilegítima - por su nacimiento "expúreo y adulterino" y en su condición de monje profeso del Císter, en tanto que maestre de la Orden de Avís- de aquel que, a la altura de 1397, detentaba el poder en Portugal, Juan I de Portugal ${ }^{293}$.

El interés por la figura del infante parece remontarse -si la datación de las cartas analizadas, siguiendo a Veas Arteseros, es la correcta-, al menos, a abril de 1397, y hubo de venir promovida, como nos informa el propio Enrique III, en buena parte, si no totalmente, por Martín Vázquez de Acuña y su linaje, de quienes parece que había partido la iniciativa de tomar voz del infante ${ }^{294}$. Bajo dicha $v o z$ fue realizada, en junio de 1397, la aludida entrada en la Beira portuguesa ${ }^{295}$ y las incursiones del maestre de Santiago, Lorenzo Suárez de Figueroa, en el reino de Portugal, por esas

${ }^{289}$ Sobre este pueden verse los apuntes recogidos en Olivera Serrano, C.: Beatriz de Portugal, pp. 122-130, 290-293; Мirot, L.: "Les mésaventures d'un prince portugais au XIVe siècle", Revue des Etudes Historiques, marzo-abril (1911), pp. 129-150, especialmente para el período estudiado pp. 149150; SuÁrez Fernández, L.: Relaciones..., p. 25; Arnaut, S.D.: A crise nacional ..., pp. 247-264.

290 Olivera Serrano, C.: Beatriz de Portugal, p. 123.

${ }^{291}$ Carta de Enrique III al maestre de Santiago, Lorenzo Suárez de Figueroa ([1397]-07-31, Salamanca), RAH, Colección Salazar y Castro, M-6, fol. 322v-323r, con un análisis de la misma en Mitre FERNÁNDEZ, E.: "Notas sobre la ruptura...", p. 220.

292 "e dali escrevia [el infante Dinis] suuas aficadas cartas e muitos do Regno secretamente, fazemdo lhe a saber que a Rainha dona Briatiz por outorguamento del Rey de Casteella poseera todo o direito que de Purtuguall tinha em elle e que elle tinha nome e titullo de Rey com todos os portugueses que em Casteella amdavã”, Lopes, F.: Crónica de D. João I, vol. II, cap. CLXXII, pp. 377-378.

${ }^{293}$ Carta de Enrique III al maestre de Santiago, Lorenzo Suárez de Figueroa ([1397]-07-31, Salamanca), RAH, Colección Salazar y Castro, M-6, fol. 322v-323r.

294 "y savedes en cómo desde Madrigal vos embié a Pero Manuel, mi donçel, con el qual vos embié dezir en cómo Martín Bázquez de Cuña,y sus Hermanos y parientes me querían servir, y querían tomar boz del ynfante D. Dinis", Carta de Enrique III al maestre de Santiago, Lorenzo Suárez de Figueroa ([1397]-06-27, Salamanca), RAH, Salazar y Castro, M-6, fols. 321v-322r. En Madrigal se encontraba el rey el 17 de abril de 1397, conforme a lo indicado en Veas Arteseros, F. de A.: Itinerario..., n ${ }^{\circ} 1.257$.

295 "E por quanto algunos les dixieron que vernía allí el Ynfante D. Donís les rrespondieron que quando lo viesen lo crerían (...) que quando entrase el Ynfante que tomaría su boz", Carta de Enrique III al maestre de Santiago, Lorenzo Suárez de Figueroa ([1397]-06-28, Salamanca), RAH, Colección Salazar y Castro, M-6, fol. 322r. 
mismas fechas ${ }^{296}$. No obstante, parece que, aunque la promoción del infante, a través de este tomar la voz, hubo de producirse en $1397^{297}$, la proclamación formal como rey de Portugal y del Algarve no tuvo lugar sino posteriormente, en abril de 1398, quizás durante la estancia de la corte en Ávila. Dicha proclamación podría ponerse en relación con el recrudecimiento del conflicto, materializado en la entrada portuguesa por la frontera del Miño, en primavera de 1398, que culminaría en el referido cerco a la ciudad de Tuy ${ }^{298}$. En este contexto, se habría proyectado desde la corte de Castilla la entrada del infante Dinis por la región de la Beira lusitana en compañía de una fuerza de dos mil lanzas, habiéndose considerado oportuno, en aquella altura, que el infante adoptara el título real, pues hubo de pensarse que, tomado dicho título, aquellos nobles descontentos con Juan I de Portugal "Ihe dariam villas e castellos como a seu Senhor natural. E que por este modo cobrariam Purtuguall" ${ }^{299}$. De este alzamiento ("que alçaron por Rey de Portogal", "quando lo alçaron por Rey"), que debió probablemente contemplar una ceremonia de acatamiento, a través del besamanos, de los exiliados portugueses en Castilla ${ }^{300}$, incluidos los partidarios de Beatriz de Portugal ${ }^{301}$, nos informa la propia Relación de efectos en dos asientos fechados en Ávila el 22 de abril, cuando Pedro Fernández, por orden de Enrique III, se encargó de forrar y en-

296 “e façed rrequerir a los más de los lugares de Portogal que pudierdes si querrán tomar la boz del Ynfante Don Donís y darse a él, e los que lo façer quisieren, mandad que los non sea fecho mal ni enojo, e los que non quisieren façer, mandadles façer la mayor guerra que podierdes", Carta de Enrique III al maestre de Santiago, Lorenzo Suárez de Figueroa ([1397]-06-28, Salamanca), RAH, Colección Salazar y Castro, M-6, fol. 322v.

297 Algunas de las fórmulas documentales de una carta de marzo de 1398 son coherentes con esta posición del infante en los meses finales del año 1397 e iniciales de 1398, previos a su proclamación regia, cuando se hable de él, en su condición de infante, aunque otorgándole un papel protagonista, aunque no unívoco, como futuro rey portugués: “otrosy por el dicho poderío vos otorgo en el dicho nonbre que sy el Infante don Donis cobrare el Reyno de Portugal como él vos faga merçet (...) E sy por aventura el dicho Rey mi Señor [Enrique III de Castilla] e otro alguno por su derecha o ayuda ovieren el dicho Reyno que eso mesmo sea tenudo de faser", a la vez que, en otro pasaje, se refería que al infante Dinis "el dicho señor Rey tiene prometido de le dar título de Rey de portugal”, Tratado entre Diego López de Estúñiga, procurador del rey de Castilla y Juan Alfonso Pimentel (1398-03-04, Zamora), AHN, Sección Nobleza, Osuna, leg. 415, doc. 5, en ARNAUT, S.D.: A crise nacional..., doc. 132, p. 521. Igualmente, otra carta anterior en el tiempo, de julio de 1397, informa de esta misma posición, que reconocía la mera condición de infante, sin asumir formalmente la posición regia, a la vez que, simultáneamente, reclamaba para él los derechos legítimos al trono portugués: "y non obedeçiendo a su Rey, y Señor natural, el qual de derecho es el Ynfante Don Donis (...) e desque naçió fasta el día de oy siempre en el Regno de Portogal le llamaron Ynfante (...) e todos aquellos que le non obedeçen nin lo rreciben por su Rey y su Señor caen en mal caso, pues de derecho el Regnado de Portogal al dicho Ynfante perteneçe", Carta de Enrique III al maestre de Santiago, Lorenzo Suárez de Figueroa ([1397]-07-31, Salamanca), RAH, Colección Salazar y Castro, M-6, fol. 323r. Tras su proclamación, incluso en el contexto de treguas, sería ya referido como "el rey don Dionís e sus gentes e subditos", Treguas de diez años entre Portugal y Castilla (1402-08-15, Segovia), AGS, PR, leg. 49, doc. 3, en SuÁrez FernÁndez, L.: Relaciones..., doc. 32, p. 137.

298 SuÁrez Fernández, L.: Relaciones..., pp. 24-25; Coelho, M.E. da C.: D. João I, p. 109.

299 Lopes, F.: Crónica de D. João I, vol. II, cap. CLXX, p. 372, con referencia a esta entrada, realizada por Sabugal, que le permitió llegar a Guarda y Viseu, en Lopes, F.: Crónica de D. João I, vol. II, cap. CLXXII, p. 376, la cual hubo de desarrollarse, según Arnaut, entre inicios de junio y mediados de julio de 1398. Cf. Arnaut, S.D.: A crise nacional..., p. 253.

300 "com todos os purtugueses que em Casteella amdavã que lhe jaa beijaram a mão por seu Rey e Senhor”, Lopes, F.: Crónica de D. João I, vol. II, cap. CLXXII, p. 378.

301 SuÁrez Bilbao, F.: Enrique III, p. 176. 
tregar al infante Dinis una hopa larga, realizada en damasco rojo entretejido con hilo de oro y forrada con setecientos veinte veros, con la que probablemente, atendiendo a la riqueza de la prenda, habría sido proclamado rey de Portugal y del Algarve ${ }^{302}$. Tras dicha proclamación, según Fernão Lopes, Dinis tomó título, estandarte y sello con las armas reales de Portugal ${ }^{303}$, llegando incluso a acuñar, como nos indica Salvador Dias Arnaut, moneda propia, bajo la forma de reales de plata ${ }^{304}$.

Para finalizar, en relación con el problema portugués desarrollado durante los reinados de Juan I y de su hijo Enrique III, es posible percibir la presencia de algunos otros portugueses en la corte castellana, con cierta probabilidad, también exiliados ${ }^{305}$, que no nos ha sido posible identificar, entre los que se encontrarían un Rodrigo Alfonso $^{306}$, un Vasco González de Ferro ${ }^{307}$, un Alfonso González de la Barrera y un Gil tal vez de apellido Vicente ${ }^{308}$.

\section{CONCLUSIONES}

La Relación de efectos ofrece informaciones de interés sobre el entorno de la cámara regia a fines del siglo XIV, específicamente, desde la perspectiva aquí abordada, sobre las estrategias de representación política desarrolladas en torno a las prácticas materiales y de consumo.

En primer lugar, a través de aquellas estrategias dirigidas a la expresión de la magnificencia cortesana en torno a la indumentaria o el ajuar doméstico. Dichos principios de lujo y de magnificencia serían expresados a través del uso de materiales ricos y/o importados y de la adhesión a un conjunto de modas como expresión de un gusto por el refinamiento y el lujo empleados como estrategia de poder. Fue frente a estas dinámicas contra las que hubieron de reaccionar durante los reinados de Enrique III y de su hijo Juan II algunos poetas y letrados cortesanos, bien desde una perspectiva moralista ${ }^{309}$, bien desde un discurso belicista, que confrontaba los viejos ideales gue-

\footnotetext{
${ }^{302}$ Relación..., (1398-04-22, Ávila), fol. 510v; Relación..., (1398-04-22, Ávila), fol. 511r.

303 "Aquelle Ifante bastardo tomou loguo titollo de Rey e chamamdose dom Dinis, Rei de Purtuguall e do Alguarve, trazemdo bamdeira e sello darmas de Purtuguall dereitas. E Martim Vasquez e os outros purtugueses (...) todos se acheguavam a elle nomeamdoo por seu Rey e Senhor", Lopes, F.: Crónica de D. João I, vol. II, cap. CLXXI, p. 374.

304 ARnaut, S.D.: A crise nacional..., p. 250.

${ }^{305}$ De un Alfonso González de la Barrera y de un Gil de probable apellido Vicente sabemos con seguridad que abandonaron a Juan I de Portugal, pues hubieron de recibir veinte varas de paño de Ypres “quando salieron de Portogal”. Relación..., (1398-01-26, Madrid), fol. 508r.

306 Relación..., (1398-01-17, Madrid), fol. 507v.

307 Relación..., (1397-12-10, Madrid), fol. 503v.

308 Relación..., (1398-01-26, Madrid), fol. 508r.

309 "¿A dó los thesoros, vasallos, servientes, / adó los firmalles, piedras preçiosas, / adó el aljófar, posadas costosas, / adó el algalia e aguas olientes, / adó paños de oro, cadenas luzientes, / adó los collares, las jarreteras, / adó peñas grises, adó peñasveras, adó las sonajas que van retinientes", SÁNCHEZ Calavera, F.: Dezir que ordenó Fernán Sánchez Calavera cuando murió en Valladolid Ruy Díaz de Mendoza (1408), ID1658, en B. Dutton; J. González Cuenca (eds.): Cancionero..., nº 530, p. 399-400, vv. 57-64; "Muéstranos glorias e delectaçiones / e en señoríos nos tiene abondados, / mugeres fermosas e ropas, mantones, / manjares diversos e muy esmerados, / thesoros, riquezas, baxillas, estrados / e joyas
} 
rreros y caballerescos con las nuevas modas cortesanas ${ }^{310}$.

En segundo lugar, a través del desarrollo de un conjunto de estrategias dirigidas a asegurar la adhesión política al poder real por medio de la entrega de presentes, en torno a la idea de la liberalidad regia ${ }^{311}$. Será la donación -bajo la noción de merced o de aguinaldo, como materialización, en el ámbito cortesano, de las prácticas de don y de contra don ${ }^{312}-$ de telas y prendas de vestir, de armas ceremoniales, de piezas de orfebrería ${ }^{313} \mathrm{o}$ de animales ${ }^{314}$ sobre la que se sustentará la dimensión material de las relaciones políticas entre cortes durante la Baja Edad Media, como nos muestra tanto

preçiosas e otras maravillas", Martínez DE Medina, D.: Dezir que fue fecho sobre la justiçia e pleitos e de la gran vanidad d'este mundo (1419), ID1466, en B. Dutton; J. González Cuenca (eds.): Cancionero..., no 340, p. 608, vv. 113-118.

310 "E dixo el capitán: “(...) Non fazen la guerra broslados, nin forraduras, nin cadenas, nin firmalles, mas puños duros e honbres denodados", Díaz de Games, G.: El Victorial, cap. 68, p. 367; "Deve ser todo cavallero bien armado y mal vestido, y deven ser las armas más fuertes que preciosas, más duras que fermosas. Lo qual no fazen los cavalleros de agora, los quales gastan más en una ropa o en pequeño anillo que en todas sus armas; assí mesmo más gastan en guarniciones superfluas que no en la principal armadura, ca a las vezez trahen muy fermoso penacho y de gran valor y trahen las armas de vil precio", SÁnchez de Arévalo, R.: Suma de la política, en M. Penna (ed.): Prosistas ..., pp. 249-309, lib. I, cap. XVII, p. 277.

${ }^{311}$ Sobre estas imágenes véanse los apuntes breves recogidos en Nogales Rincón, D.: "Los espejos de príncipes en Castilla (siglos XIII-XV): un modelo literario de la realeza bajomedieval", Medievalismo: Boletín de la Sociedad Española de Estudios Medievales, 16 (2006), pp. 9-39, p. 23.

312 Sobre este aspecto, cabe destacar, entre otros, los siguientes trabajos, cuya consulta no siempre ha sido posible: Prado-VILAR, F.: "Arte y diplomacia: del regalo en las relaciones con Oriente", en $\mathrm{Al}$ fonso X El Sabio, Murcia, 2009, pp. 186-189; OCHOA Brun, M.Á: Historia de la diplomacia española. Vol. III. Edad Media III, Madrid, 1991, pp. 402-412; OchOA Brun, M.Á: Historia de la diplomacia española. Vol. IV. Los Reyes Católicos, Madrid, 1995, pp. 469-478; Damen, M.: "Gift exchange at the court of Charles the Bold", en In But Not of the Market. Movable Goods in Late Medieval and Early Modern Urban Society, Bruselas, 2007, pp. 81-99; DAMEN, M.: "Princely entries and gift exchange in the Burgundian Low Countries: a crucial link in late medieval political culture", Journal of Medieval History, 33 (2007), pp. 233-249; CuTLER, A.: "Significant gifts: patterns of exchange in late antique, Byzantine, and early Islamic diplomacy", Journal of Medieval and Early Modern Studies, 38:1 (2008), pp. 79-101; LaRubia-Prado, F.: "Gift diplomacy: the role of the horse in the Cantar de mio Cid", La Corónica: A Journal of Medieval Spanish, 37:1 (2008), pp. 275-299; CuRTA, F.: "Merovingian and Carolingian gift giving", Speculum: A Journal of Medieval, 81:3 (2006), pp. 671-699; Whiтe, S.D.: "The politics of exchange: gifts, fiefs and feudalism", en Medieval Transformations: Texts, Power, and Gifts in Context, Leiden, 2001, pp. 169-188; Díez Jorge, M.E.: "Misivas de paz en las relaciones diplomáticas: regalos y presentes entre reinos", en III Estudios de Frontera: Convivencia, defensa y comunicación en la frontera, Jaén, 2000, pp. 219-233; StRATFORD, J.: "Gold and diplomacy: England and France in the reign of Richard II", en England and the Continent in the Middle Ages: Studies in Memory of Andrew Martindale, Stamford, 2000, pp. 218-237; Muthesius, A.: "Silken diplomacy", en Byzantine Diplomacy, Aldershot, 1992, pp. 237-248; Buettner, B.: "Past Presents: New Year's Gifts at the Valois Courts, ca. 1400", The Art Bulletin, 83:4 (2001), pp. 598-625; Guerreau-Jalabert, A.: "Caritas y don en la sociedad medieval occidental", Hispania: Revista Española de Historia, 204 (2000), pp. 27-62; EICHBERGER, D.: "The culture of gifts. A courtly phenomenon from a female perspective", en Women of distinction: Margaret of York and Margaret of Austria, Lovaina, 2005, pp. 287-295; HEAL, F.: "Reciprocity and exchange in the late medieval household", en Bodies and Disciplines. Intersections of Literature and History in Fifteenth-Century England, Minneapolis, 1996, pp. 179-198.

313 Para el propio reinado de Enrique III contamos con los testimonios relativos a los regalos remitidos por el Duque de Berry a Catalina de Lancaster y Enrique III de Castilla, abordados en Domenge I Mesquida, J.: "Regalos suntuarios: Jean de Berry y la realeza hispana", en El intercambio artístico entre los reinos hispanos y las cortes europeas en la Baja Edad Media, León, 2009, pp. 343-364, pp. 350-353. 
la propia Relación de efectos, como algunos testimonios casi coetáneos a la misma ${ }^{315}$. Aunque tal aspecto debería quedar, por el momento, en el ámbito de lo hipotético, parece posible sugerir tal vez el inicio, en el último tercio o cuarto del siglo XIV, de un proceso de cambio lento y progresivo en torno a la percepción de los modelos suntuarios en la corte de Castilla, en el que tuvo que ver no poco el mimetismo y los intercambios culturales operados con ocasión de los contactos y alianzas diplomáticas entre cortes, y la frecuente presencia de tropas extranjeras en el territorio de la Península durante la segunda mitad del trescientos. Dicho proceso supondría el tránsito desde un modelo que podríamos denominar como tradicional, que haría especial hincapié en la idea de riqueza material centrada en productos de consumo como los paños de oro, el aljófar o las piedras preciosas, claramente perceptible en sus aspectos fundamentales, al menos, desde la segunda mitad del siglo XIII, hacia otro que, sin dejar en modo alguno de lado esta concepción, diversificaría su atención hacia nuevas producciones y formas de expresión suntuarias ligadas a renovadas modas ceremoniales y de consumo que culminarían, a lo largo del siglo XV, en el conocido genéricamente como modelo franco-borgoñón ${ }^{316}$. A modo de propuesta, en el marco de este nuevo modelo de consumo quizá se prestaría una mayor atención a la calidad estilística y artística y al carácter importado de ciertos productos, un interés creciente por las formas artísticas progresivamente adaptadas al gusto tardogótico de raíz franco-borgoñona y una adhesión por las modas cortesanas internacionales en línea con el referido modelo, capaces de articular, junto al aporte italiano, una referencia estética global sobre la que preferentemente se articularían las relaciones diplomáticas entre cortes y, más ocasionalmente, las relaciones políticas en el seno de la Corona a fines de la Edad Media. Dicho modelo suntuario se encontraría caracterizado a fines del siglo XIV por elementos como: la preponderancia de la hopa-

${ }^{314}$ Además de los citados alanos regalados por Enrique III al rey de Aragón, cabe citar la mula "ensellada e enfrenada", regalada al francés Roberto Sanluces y a su ayo, Lobete. Relación..., (1397-12-04, Madrid), fol. 503r; Relación..., (1397-12-25, Madrid), fol. 505v [asiento tachado].

315 "E por fazer conprar ende mulas e paños de oro e de sirgo para dar en presente a los extranjeros que vinieron a la guerra, por los contentar e enbiar pagados", García de SANTA María, A.: Crónica de Juan II..., cap. 82, p. 189; "E troxo [el embajador del rey de Granada] presente al rey e al Infante: al rey, tres cavallos e tres espadas de plata, ginetas, e paños de sirgo, e figos, e pasas, e fruta; e al Infante dos cavallos e dos espadas ginetas, e paño de sirgo, e fruta", García de SANTA María, A.: Crónica de Juan II..., cap. 122, p. 267; "El Rey y la Reyna y el Infante rescibieron muy graciosamente el Embaxador con el presente, é mandóle dar caballos y mulas e vaxilla de plata e piezas de seda", Pérez DE GUzMÁn, F.: Crónica del serenísimo príncipe don Juan segundo..., año 1411, cap. XIX, p. 339; "E dende a quatro meses, el Rey Don Juan embió al Rey de Francia caballos de la brida, ensillados y enfrenados muy ricamente, y doce halcones neblís, los capirotes guarnidos de perlas e rubíes, e los cascabeles y tornillos de oro muy bien obrados; y embióle muchos cueros de guadamecir e muchas alhombras, porque es cosa que en Francia no se han; y embióle un león e una leona con collares de oro muy rico, e dos abestruces, e dos colmillos de elefante los mayores que jamás hombre vido, que el Rey de Túnez le había enviado", Pérez de GuZMÁn, F.: Crónica del serenísimo príncipe don Juan segundo..., año 1411, cap. XX, p. 339.

316 Sobre este modelo ceremonial, véase el trabajo de Fernández de Córdova Miralles, A.: "L'impact de la Bourgogne à la cour castillane des Trastamare", en La cour de Bourgogne et l'Europe: Le rayonnement et les limites d'un modèle culturel, Ostfildern, 2013, pp. 593-630; KNIGHTON, T.: "Northern influence on cultural developments in the Iberian Peninsula during the fifteenth century", Renaissance Studies, 1:2 (1987), pp. 221-237. Nogales Rincón, D.: "Sobre la cultura borgoñona y su recepción en Castilla en el siglo XV", en La Casa de Borgoña. La Casa del rey de España, Lovaina, 2014, pp. 23-35. 
landa; la amplia influencia en el vestido de los modelos asociados a la indumentaria militar; el interés por la decoración de las prendas con elementos metálicos y por el forrado con pieles; la atención hacia ciertas piezas de orfebrería como emblema del nuevo modelo suntuario, como los firmales, los collares, las copas con sobrecopa decorada o las armas de ceremonia ${ }^{317}$; la atención, en el ámbito de la orfebrería, hacia técnicas decorativas como el esmalte; o el interés progresivo por los tapices o paños franceses, que, aunque no mencionados en la Relación de efectos, son conocidos por documentación coetánea ${ }^{318}$.

La definición de este nuevo modelo suntuario fue simultáneo y paralelo al proceso de recepción de nuevas pautas culturales, en buena parte enmarcadas, de una forma genérica, en el ya referido modelo tardogótico: el sistema de emblemas individuales, basado en el uso de divisas personales, que sentará las bases de la cultura cortesana durante el reinado de Juan II; una transición hacia nuevas formas musicales polifónicas; el progresivo interés por el uso de catafalcos como estructuras efímeras propias del ceremonial funerario; $y$, aunque la cronología al respecto no sea clara, quizás la incorporación de la referida cortina u oratorio al ceremonial religioso de la realeza.

317 Algunas de estas producciones suntuarias aparecerán sistematizadas en diversas fuentes literarias, que se suman a los testimonios, ya referidos, ofrecidos por Fernán Sánchez Calavera, Diego Martínez de Medina o Gutierre Díaz de Games, como expresión por excelencia del lujo y la magnificencia: "Aquí declara cómo la real casa de Dido fue prestamente mejor guarnesçida que en los otros días, e por eso dize: en la cual fue aparejado el real combate en la real sala, e por eso dize en público, en el cual se mostraron las ricas vestiduras brosladas e con labores, e por eso dize por arte labradas. E sobrrellas firmalles e collares e chapilletes e çintas e espadas de fermosas lavores, que ya estonçe se usavan. E por eso dize: nobles guarnesçimientos, a demostrar que la reina e sus gentes se guarniçieron e vistieron apuestamente e festival por honrar la fiesta e combite", VillenA, E. de: Traducción y glosas de la Eneida. Libros I-III, ed. de P.M. Cátedra, Madrid, 1994, p. 196; "Non fazen la guerra broslados, nin forraduras, nin cadenas, nin firmalles", DíAz de GAMEs, G.: El Victorial, cap. 68, p. 367.

318 "El paño françés de Lançarote", Cédula de Catalina de Lancaster pidiendo a María de Ayala que entregara al camarero real Francisco Fernández los objetos de la cámara y capilla de la reina que con anterioridad le había prestado (1400-11-16, Montejo de Arévalo), en CAÑAS GÁlvez, F. de P.: Colección diplomática de Santo Domingo el Real de Toledo: documentos reales. I, 1249-1473, Madrid, 2010, doc. 55, p. 105. 